\title{
Microsporidia: A Review of 150 Years of Research
}

\author{
C. Franzen*
}

Department for Internal Medicine I, University of Regensburg, Regensburg, Germany

\begin{abstract}
Microsporidiology is a field of science with a rather long history beginning in the middle of the 19th century when a microsporidian infection of the silkworm devastated the European silkworm industry. Several other microsporidia, mainly in insects and fish, were later described, but these organisms seemed to be mere curiosities for several years. However, when it became clear that microsporidia were causing economically important diseases in insects and fish and more recently, in mammals and even in humans with immunodeficiency, microsporidia have become a favourite subject for biologists studying intracellular parasitism and molecular phylogeny. This review summarizes 150 years of microsporidian research and traces the role of the microsporidia and of microsporidiology in biology and medicine.
\end{abstract}

\section{INTRODUCTION}

On October 30,1857, a small report from a lecture given by Carl Wilhelm von Nägeli (Fig. 1) on September 21, 1857 in Bonn at the 33. Versammlung Deutscher Naturforscher und Ärzte, Über die neue Krankheit der Seidenraupe und verwandte Organismen (On the new disease in the silkworm and related organisms), appeared in the 44th issue of the Beilage zur Botanischen Zeitung (Fig. 2). In this talk, the organism responsible for the European silkworm disease was called Nosema bombycis [1,2]. A similar lecture was given
Botanischen Zeitung was the first in the literature to mention a named microsporidium, although Nägeli regarded it as a yeast and placed it in the Schizomycetes, which at the time was a conglomeration containing yeast and bacteria.

In the 19th century the silkworm disease caused by this microsporidium ravaged the European silkworm industry, almost completely destroying silk production in France and Italy. Several researchers, of whom the most prominent was Louis Pasteur (Fig. 3a), had been investigating the disease affecting the silkworm Bombyx mori since 1845. Pasteur's

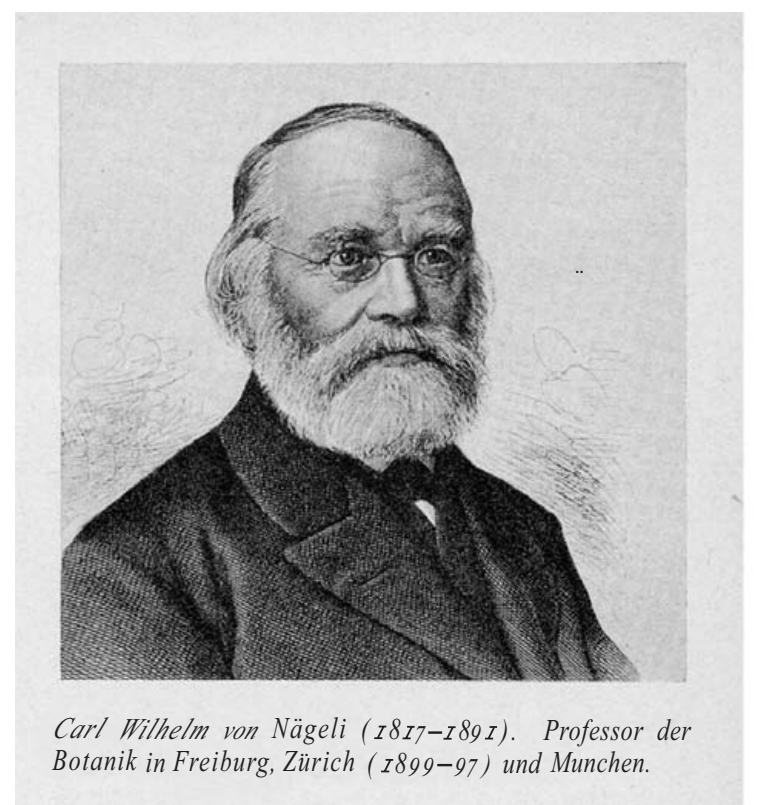

\section{TAGEBLAT T}

\section{NATURFORSCHER UND ÄRZTE}

IN BONN IM JAHRE 1857.

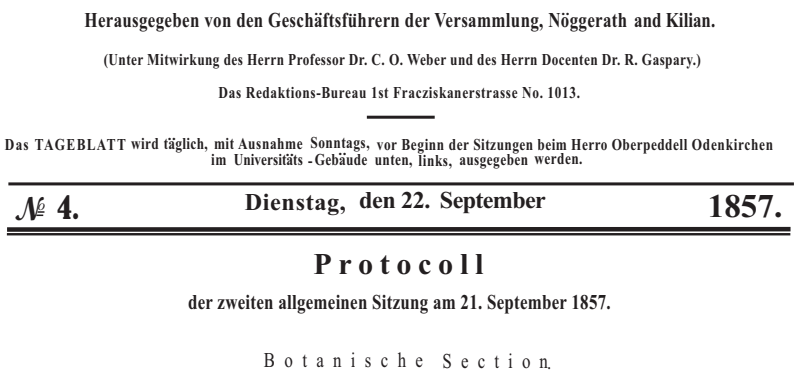

Prof. Na g geli: über die neue Krankheit der Seidenraupen und verwandte Organismen. Die Gebilde, welche dia Seidenraupe zerstören, sind ein einzelliger Pilz, welcher sich durch Theilung ver-
mehrt und als Nosema bombyeis mit Ulvina aceti, Hygrocrocis, Bacterium, Spirillum, Vibrio und Sarcina die neue Pilzgruppe Schizomycetes begrïndet.

Fig. (1). (a) Carl Wilhelm von Nägeli (1817-1891) was professor of botany in Fribourg, Zurich, and Munich. Reprinted with permission from [4]. (b) Tageblatt der 33. Versammlung deutscher Naturforscher und Ärzte in Bonn im Jahre 1857 where Nägeli gave his talk about Nosema bombycis [2].

by Nägeli in Zurich, where he also proposed the name Nosema bombycis [3], but the report in the Beilage zur

*Address correspondence to this author at the Klinik und Poliklinik für Innere Medizin I, Universität Regensburg, Franz-Josef-Strauß Allee 11, 93042 Regensburg, Germany; Tel: ++49-(0)941-944-7169; Fax: ++49(0)941-944-7169; E-mail: Caspar.Franzen@Klinik.Uni-Regensburg.de former teacher, the chemist and bacteriologist Jean-Baptiste Dumas, who also served as minister of agriculture and commerce, asked Pasteur in 1865 to head a commission of the Department of Agriculture to see what could be learned about this disease that was destroying the French silk industry. For centuries, the production of silk had been an important industry in southern France, and by 1853 it had achieved such importance that French sericulture was estimated to be 


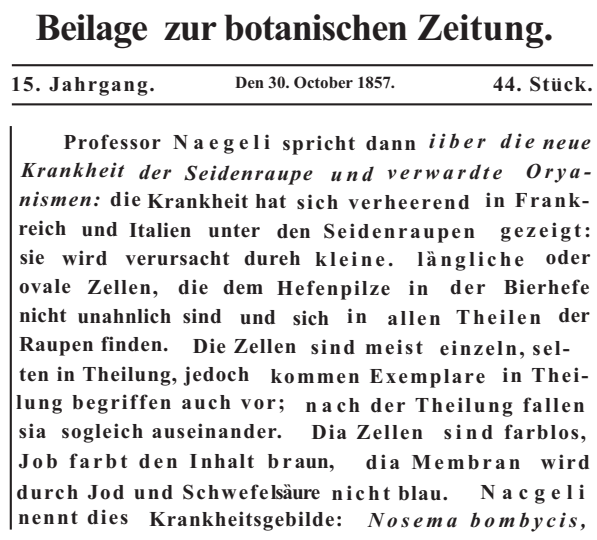

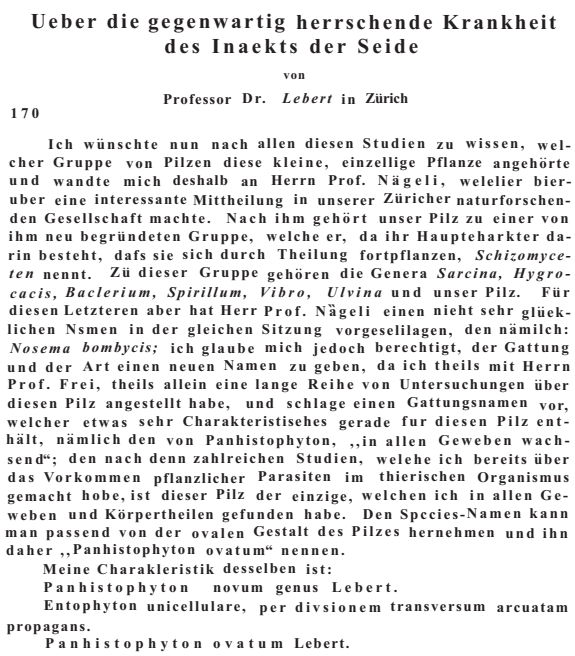

Fig. (2). (a) Report in the in the 44th issue of the Beilage zur Botanischen Zeitung about the talk of Nägeli [1]. (b) Extract from a paper of Lebert (1856-1857) dealing with the naming of Nosmea bombycis [3].

responsible for a tenth of silk production worldwide but within 10 years, French production had plummeted by almost 70 percent $[5,6]$. From France, the disease spread to Italy, Spain, and Germany, where silk production had been promoted by Frederick the Great of Prussia since the end of the 18th century [3], and in 1860 the German silk industry was nearly totally destroyed by the silkworm disease.

Even though Pasteur knew nothing about silkworms and had no idea that they suffered from disease, his subsequent research on the silkworms contributed significantly to the establishment of insect pathology as a science. Diseased silkworms were covered with blackish blotches and Jean Louis Armand de Quatrefages de Bréau, professor of natural history at the Lycée Napoléon in Paris, who was also investigating the silkworm disease, had called the disease "pébrine" (which in the dialect of southern France meant "pep- per disease") (Fig. 3b) [6, 8]. In Germany it was called "Fleckenkrankheit" ("spot disease"). German, Swiss and Italian researchers of that time had already noticed that the tissues of affected silkworms always contained tiny, oval bodies [3, 9-13], called "Cornalia'sche Körperchen" or “corpuscles of Cornalia" (after the publications of Emilio Cornalia from Italy) (Fig. 3c), but only Pasteur proved that the disease was really caused by this parasite (later determined to be $N$. bombycis by Balbiani [14] and Stempell [15]).

Lebert from Zurich was among the first who identified the oval bodies in diseased silkworms [3]. He had shared most of his results with Nägeli, at that time also in Zurich, and felt that Nosema bombycis was a rather improper name for this organism, although he also believed that it was a yeast. He suggested Panhistophyton ovatum (Fig. 2) [3], but this naming was not widely accepted [16] and is not sup-
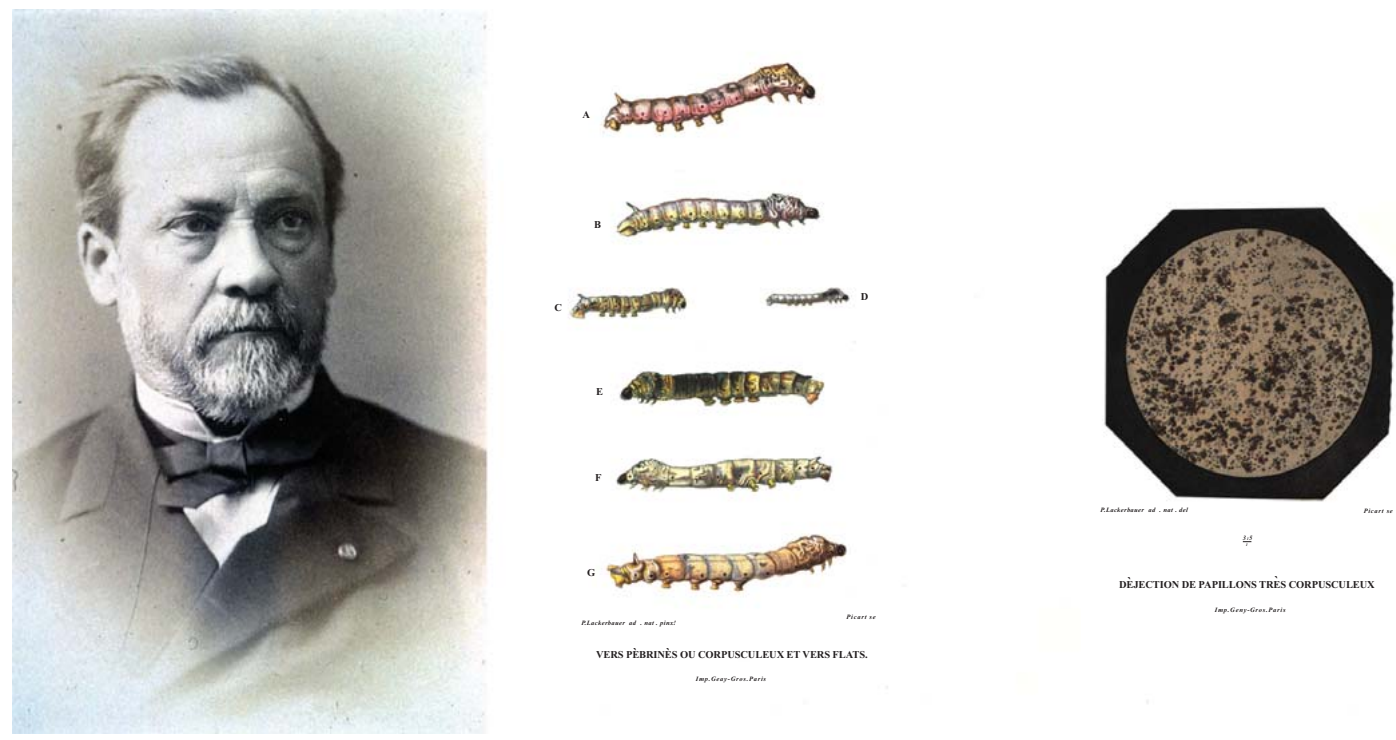

Fig. (3). (a) Louis Pasteur (1822-1895) in 1881. CInstitut Pasteur. Reprinted with permission of the Institut Pasteur, Paris, France. (b) Colour plate showing diseased silkworms and (c) microsporidian spores from silkworms from Pasteur's Études sur la maladie des vers à soie. Reprinted with permission of the Institut Pasteur, Paris, France [7]. 
ported by the current rules of the International Code of Zoological Nomenclature [17].

In 1870, Pasteur published his landmark studies Études sur la maladie des vers à soie (Studies on the disease of the silkworms), in which he described methods for controlling and prevention of pébrine disease in silkworms (Fig. 4) [7]. After five years of research, Pasteur had found the parasite not only in the silkworms but also in their moths and ova. Similar results had been previously published by Vittadini in 1859 who showed that the disease was transmitted by the ova [18]. Pasteur showed that the plague could be successfully overcome by a systematic microscopic examination of silkworms and ova with elimination of all those found to be diseased. He instructed silkworm farmers on these selection methods and in use of the microscope to detect illness in the silkworms. At first, the farmers were reluctant to use the microscope, but after Pasteur's daughter Zizi demonstrated how easy it was to identify silkworms that were free of pébrine, the farmers adopted Pasteur's method (this story is told in a nice children's book by Thomson [19]). This work essentially saved the silkworm industry worldwide and was a primary influence on Pasteur in the development of his germ theory of disease.

A few of the microsporidia were already observed before Nosema bombycis was named in 1857. The earliest report of a microsporidian parasite was probably given by Gluge in 1838, who reported a parasite (later determined to be Glugea anomala [20]) from a fish host [21] and similar organisms were observed by Creplin in 1842 [22] and Müller (1841) [23]. However, Nägeli's talk on Nosema bombycis 150 years ago is considered the beginning of microsporidiology.

The taxonomic designation of the newly recognized organisms was controversial for several years, and researchers regarded them variously as unicellular alga, nuclei of degraded erythrocytes, tumor cells, or yeast spores (Schizomy- cetes) [24]. Most researchers regarded them as herbal organisms, which was still supported by Rudolph Leuckart and Otto Bütschli in their famous works on parsites [25] and protozoa [16]. Balbiani, after a series of studies on the silkworm pathogen, recognized that the organism lacked several Schizomycetes characteristics but shared similarities with the Sporozoa Leuckart, 1879 [14]. Consequently, in 1882 Balbiani was the first to suggest the separate taxon Microsporidia (Microsporidies) for $N$. bombycis, which was the only named microsporidium at that time, and also for a few related, then unnamed species (the taxon's level was not specified, but Balbiani implicitly ranked it as an order by making it a fifth "groupe" in the "Sporozoaires") [14]. Even so, Sprague in 1977 designated the phylum Microspora [26], which was updated in 1992 [27]. This designation caused some confusion until 1998, when Sprague and Becnel acknowledged Microsporidia Balbiani, 1882 as the correct name-authordate combination for this phylum [28].

After the attention of biologists turned to the microsporidia in silkworms, it was found that similar organisms were widely distributed among various kinds of animals [13] and long before they were described as human pathogens, they were well known as a cause of disease in many nonhuman hosts, particularly invertebrates and fish. In 1899, the French protozoologist Alphonse Labbé, although he did not study microsporidia himself, gave the first complete review of the microsporidia (on $8 \frac{1}{2}$ pages) and listed one family, three genera, and 33 named and 20 unnamed species (Fig. 5a) [29].

Important species have been described susequently: Nosema apis, a microsporidium frequently responsible for an epidemic disease among honeybees, was described by Zander in 1909 [30], but a similar organism had already been seen in the gut of infected bees by Dönhoff and Leuckart in 1857 , although they regarded it as a yeast [25, 31-33]. They

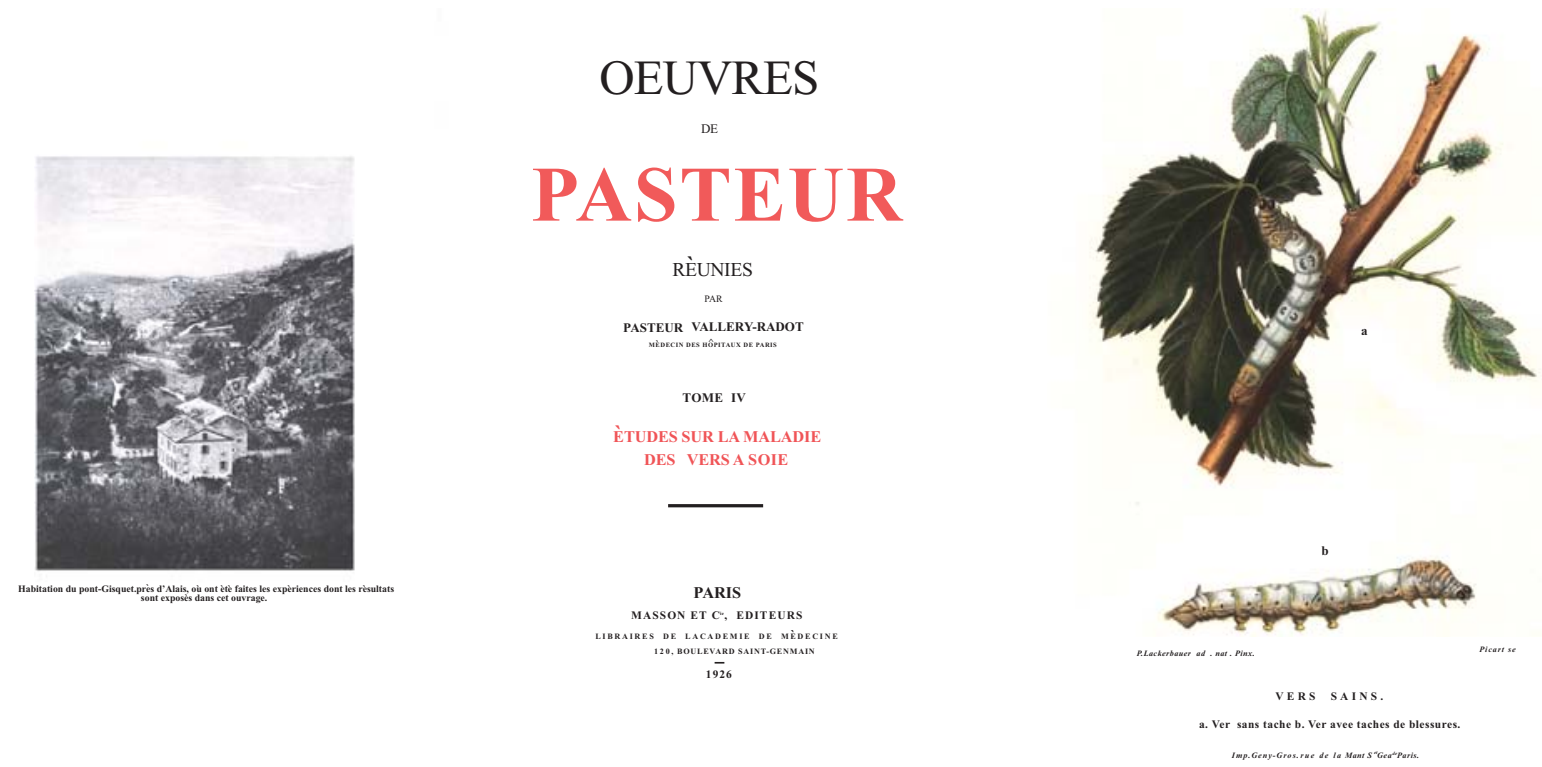

Fig. (4). (a) Pasteur's famous study on silkworm disease, Études sur la maladie des vers à soie, published in 1870. On the left is a copper engraving of what was the Pasteur family home near Alès during his work on the silkworm disease and which is now a museum open to visitors. (b) Colour plate showing healthy silkworms from Études sur la maladie des vers à soie. Reprinted with permission of the Institut Pasteur, Paris, France. A copy of this rare and expensive book has been made available by the Bibliothèque nationale de France and can be obtained at http://gallica.bnf.fr. 
suspected also that this organism was responsible for dysentery in infected bees and showed that the organism could be transmitted between bees by feeding [32, 33]. Nosema bombi, a microsporidium pathogenic to bumblebees was described by Fantham and Porter [34]. These researchers also considered $N$. apis as the cause for the so-called "Isle of Wight Disease" that had begun killing honeybee colonies on the island in 1904 and had nearly wiped out all hives by 1907 when the disease jumped to the mainland and decimated beekeeping in the British Isles [35]. However, this disease was not caused by a microsporidium and the cause of the mystery ailment was not identified until 1921 when the parasitic mite, Acarapis woodi, was first described by Rennie [36]. The microsporidium, Glugea anomala, which had already been seen by Gluge in 1838 [20], was named by Moniez in 1887 [21]. This microsporidium and Pleistophora typicalis, originally described by Gurley in 1893 [37] based on a report of Thélohan from 1891 [38], are microsporidia infecting the muscles of fish. Gurley in 1893 and 1894 was also the first to summarize the microsporidia that infect fish [37, 39].

Many of these early studies were obviously influenced by Pasteur, and several publications in that period were produced by French researchers. The most notable researcher of this period was the French protozoologist Louis Léger, who published, together with O. Duboscq, one of his students in Grenoble, and with E. Hesse many papers describing several major groups of microsporidia [40-45]. In 1922, Léger and Hesse presented a classification of the microsporidia that was used with slight modifications for several decades [46]. The material used in these studies was mainly collected dur- ing practical courses of zoology at university field stations near Grenoble and Montpellier in France [47].

Other people working with microsporidia during this time included H. B. Fantham and A. Porter in the UK [34, 35] and P. Debaisieux, C. Pérez, L. Mercier, and P. Thélohan in France, who contributed significant findings to microsporidian morphology [38, 48-56]. Thélohan, who worked in Balbiani's laboratory, was also among the first who tried in 1892 to set up a classification system for the microsporidia [53] that he revised three years later in his splendid work on Myxosporidia [55]. The genus Thelohania Henneguy, 1892 was named to honour him [57].

In Germany, W. Stempell in Greifswald and later in Münster, after dedicated studies on Thelohania mülleri [58], Glugea anomala [59], and Nosema bombycis [15], summarized his results in several important papers that he illustrated with beautiful figures, including several photos in black-and-white and even colour. Stempell also contributed one of the first classification systems for the microsporidia [15]. The genus Stempellia Léger \& Hesse, 1910 was created to honour him [60]. R. Weissenberg from Berlin worked mainly on fish microsporidia (Glugea), and in 1922 he introduced the term "Xenon" (derived from $\delta \xi \varepsilon v \omega$ v $=$ the guesthouse, later developed to "xenoma" from Weissenberg's work [61] and from a paper of Chatton [62]) for the formations induced by some microsporidia in fish [63-65]. Other German researchers included F. Doflein from Munich [6669], L. Pfeiffer from Weimar [24], M. Auerbach from Karlsruhe, who worked mainly on Myxosporidia and who published an excellent monograph on Myxo- and Mi-

\section{Das Tierreich.}

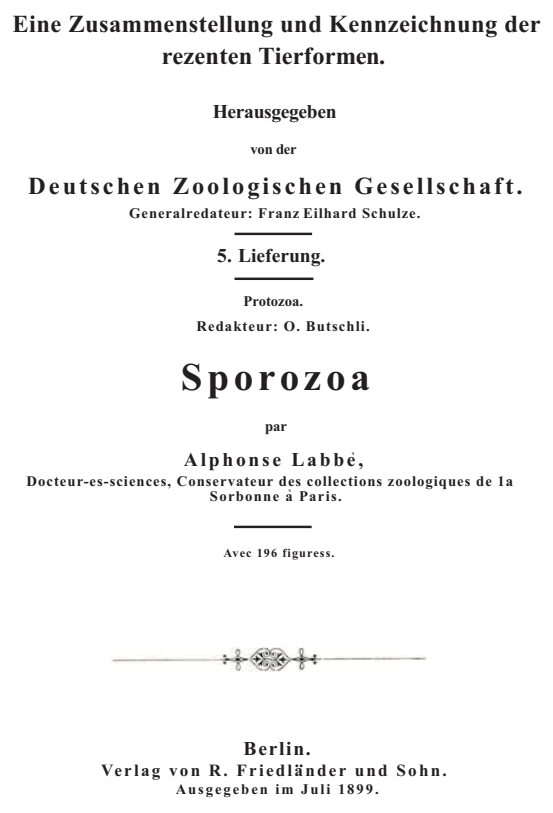

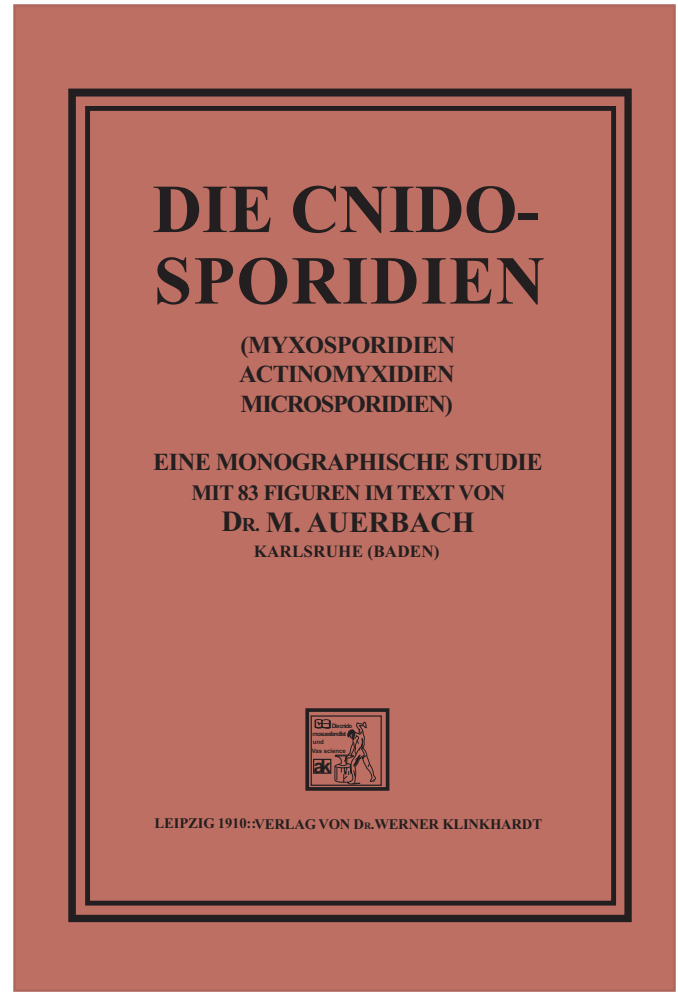

Fig. (5). Early monographs dealing with microsporidia. (a) Labbe's famous book about Sporozoa containing the first complete review of the microsporidia published in 1899 [29]. (b) Monograph Die Cnidosporidien of Auerbach published in 1910 [70]. 


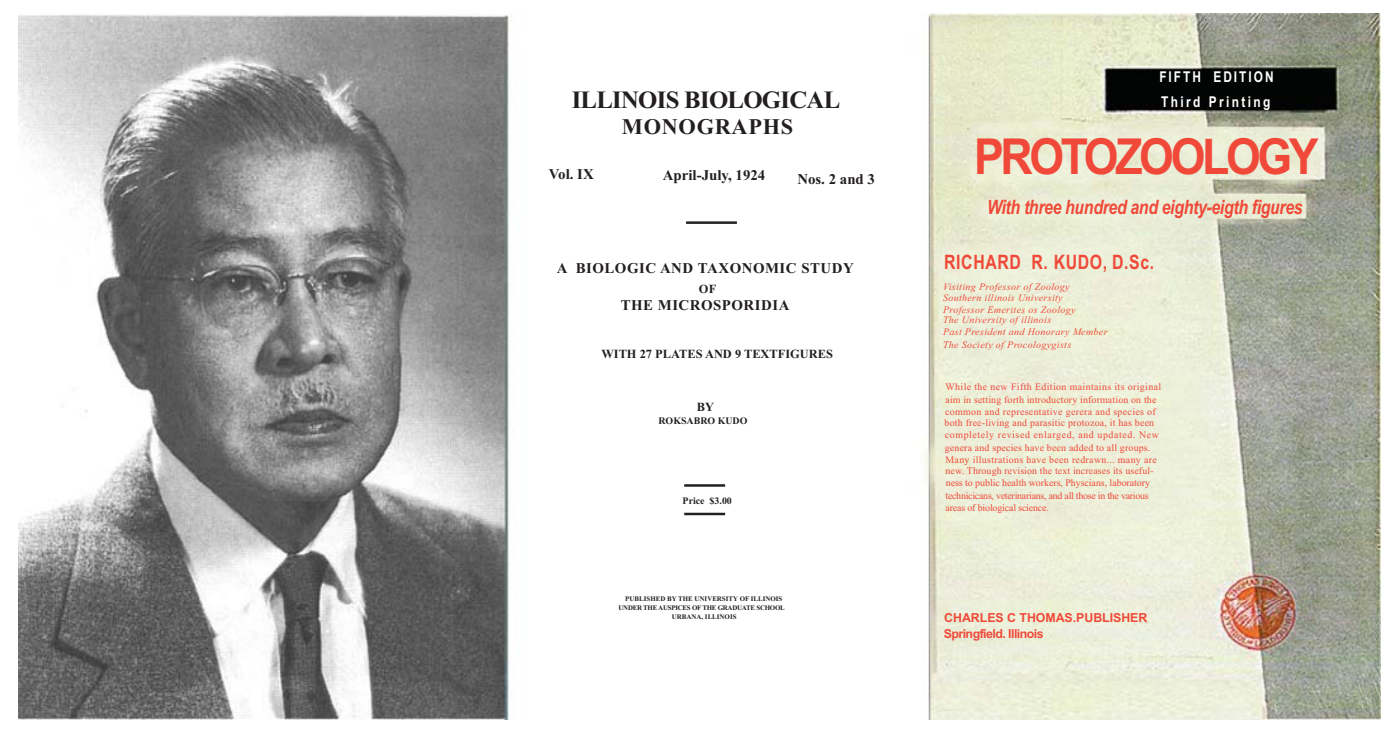

Fig. (6). (a) Richard Roksabro Kudo (1886-1967). Photo courtesy of W. Muhlach, Southern Illinois University Carbondale, printed with permission from Wittner and Weiss 1999. (b) Kudo's 1924 monograph, A Biologic and Taxonomic Study of the Microsporidia, summarizing the respective state of knowledge of the microsporidia [73]. (c) Fifth edition of Kudo's famous textbook Protozoology [87].

crosporidia in 1910 (Fig. 5b) [70], W. Nöller from the Bernhard Nocht Institute in Hamburg [71], and W. Zwölfer, at that time in Tübingen, where in 1924 he did his doctorate about microsporidia [72], who all contributed significantly to our knowledge of the microsporidia.

The splendid monograph, A Biologic and Taxonomic Study of the Microsporidia, summarizing the respective state of knowledge on the microsporidia was published by $\mathrm{R}$. Kudo in 1924, and 25 years after Labbé's work, Kudo listed four families, 14 genera, and 178 species, including some unnamed and doubtful ones [73]. The bibliography of this critical review contains already 223 titles (a reprint of this book was done in 1970 by Johnson Reprint Corporation). Richard Roksabro Kudo (Fig. 6) was the most illustrious protozoologist of his time. He published many excellent papers on Microsporidia and Myxosporidia. From 1918 to retirement in 1954, which encompassed most of his professional career, he was with the Department of Zoology at the University of Illinois, Urbana, where other famous microsporidian researchers followed in his footsteps. One of these was John Paul Kramer, who was probably the first to observe the sporoplasm of a microsporidium passing through an extruded polar tube [74], and who described Nosema kingi (now Tubulinosema kingi) in Drosophila [75] and Nosema necatrix (now Vairimorpha necatrix) [76] and several other species. Others were Nelda Alger, who saw microsporidia in an infected mosquito colony (Alger's only work on microsporidia [77]) and then put Albert Undeen, then her student, under Vávras guidance for describing it [Anncaliia algerae (then Nosema algerae)] [78]; Joseph Maddox, who began microsporidian research with his Ph.D. thesis on a microsporidiosis of the armyworm [79] and who described several microsporidian species pathogenic to insects; and Albert Undeen (now in Gainesville, Florida), who contributed important investigations on the extrusion of the polar filament [80-83] and who published a very useful book on research techniques used in microsporidiology [84] that is available at http://www.modares.ac.ir/elearning/Dalimi/ Proto/Lectures/week15/content.htm. And Illinois remains a center of important microsporidian research; for example, the Illinois Natural History Survey harbours the world's largest and most diverse collection of living entomopathogenic microsporidia preserved in liquid nitrogen.

In 1931 Kudo published his Handbook of Protozoology, which was widely used in protozoology courses at that time [85], and which became the famous textbook Protozoology with the publishing of the second edition in 1939 [86]. The fifth edition of this masterpiece of protozoological morphology and taxonomy was published in February, 1966 and the third printing of this fifth edition from 1977 is still available today [87]. Many of Kudo's publications include beautiful drawings that he prepared using an aqueous suspension of Chinese ink and a brush (Fig. 7). He was one of the few honorary members of the Society of Protozoologists (now the International Society of Protistologists) and served as its president in 1953. The Society for Invertebrate Pathology honoured him with its Founder's Lecture in 1989, given by Victor Sprague [88]. Kudo was undoubtedly the first researcher to engage in microsporidian research throughout his academic career. Already his thesis research in Japan was on Nosema bombycis, and his first publication (written in German) concerned a new method for making permanent preparations of Nosema bombycis spores with their polar filaments everted [89]. Thus, his first publication was related to microsporidia, as were a majority of his later ones [90-93].

Kudo's original intention was to update his work on microsporidia with a supplement every 10 years [88], but he ultimately did not have to. Otto Jírovec (Fig. 8) - founder of the Institute for Protozoology and Parasitology in Prague, father of microsporidia research in the Czech and Slovak republics, and also an honorary member of the Society of Protozoologists - updated Kudo's monograph in 1936 [94]; his supplement contained 3 additional genera, 58 additional species, and a bibliography with 106 additional titles. In this 

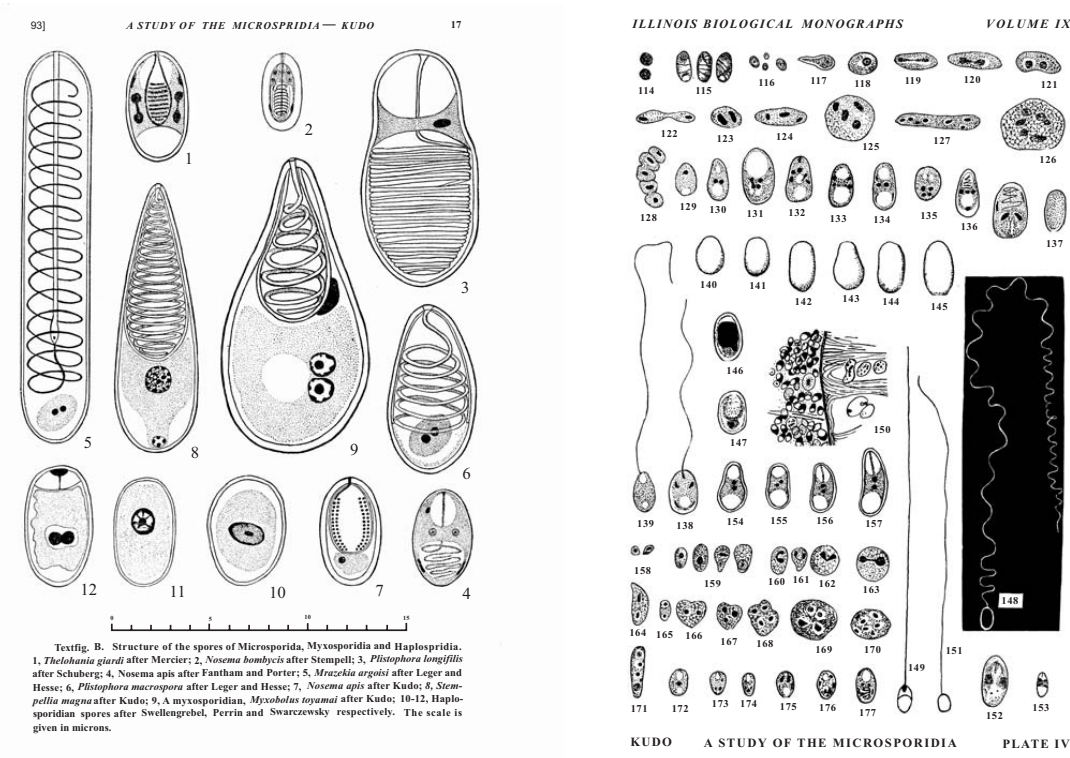

Fig. (7). Line drawings from Kudo's A Biologic and Taxonomic Study of the Microsporidia [73] showing the structure of (a) several spores of microsporidia, myxosporidia and haplosporidia and (b) of several Nosema spp. including N. apis (114-148), N. pulicis (151-153), and N. bombi (158-177).
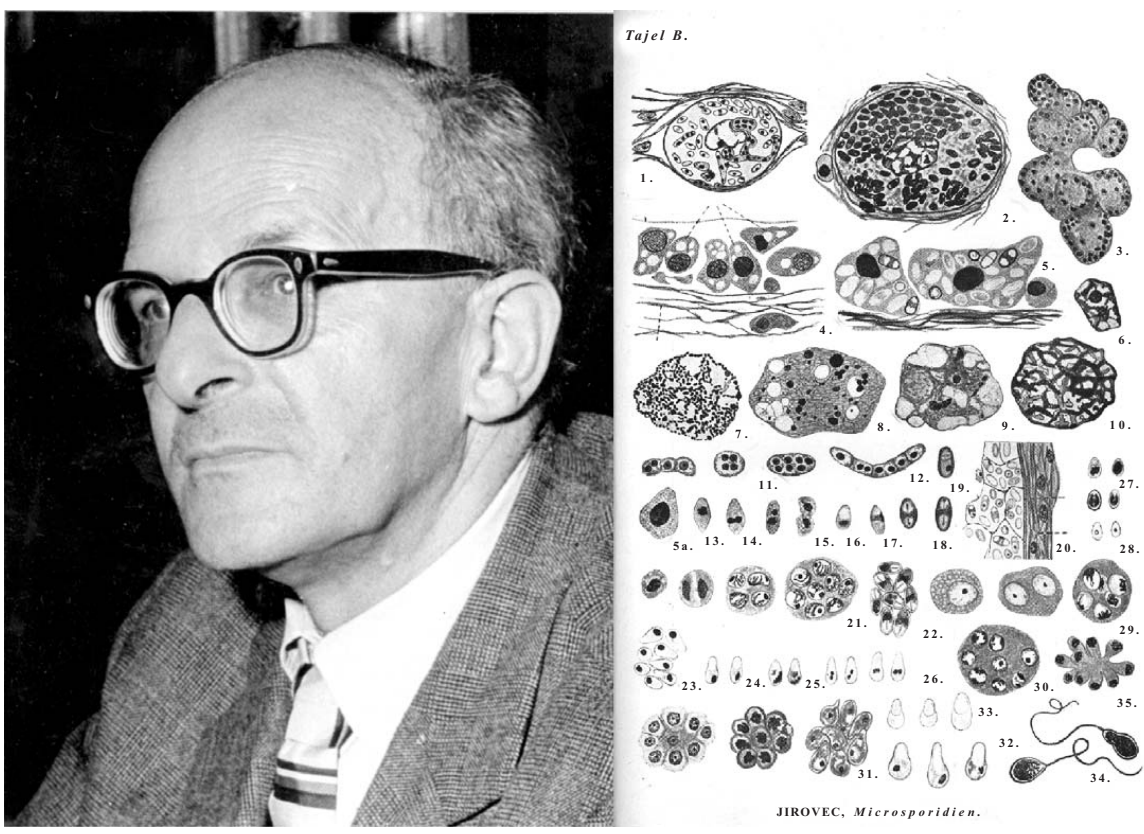

Fig. (8). (a) Otto Jírovec (1910-1972), the founder of microsporidia research in the Czech and Slovak republics. (b) Plate from Jírovec O. (1936), Studien über Mikrosporidien. Vestn Cesk Spol Zool 4:1-75 [94] showing Glugea acerinae (1-20), Thelohania cladocerca (21-26), Plistophora intestinalis (27-28), and Plistophora obtusa (29-34). Printed with permission of the Department of Parasitology, Charles University, Prague, Czech Republic.

work, Jírovec proved that microsporidian spores always contain only one or two nuclei, as Weissenberg, Debaisieux, Kudo, and Zwölfer had thought, although Thélohan, Stempell, Léger and Hesse, and Mercier had proposed that microsporidian spores contained several (5-6) nuclei. The genera Jirovecia Weiser, 1977 [95] and Jiroveciana Larsson, 1980 [96] were named to honour Jírovec's outstanding work. Jírovec was an ardent photographer, and he was among the first to photograph much of what he saw under the micro- scope (Fig. 9). Many of his photos have served as illustrations in books and papers (including the update mentioned above) published by Jírovec and other authors. The best and most beautiful have been published in Jírovec's splendid book, Life under the Microscope, written with Bouček and Fiala and published in various European languages [97]. Many of his black-and-white negatives are housed at the Institute of Parasitology in Prague and are available at http://parasite.natur.cuni.cz/collections/welcome. html. 
In 1947, Jaroslav Weiser (Fig. 10), whose interest in microsporidia was initiated by Jírovec, published a key to the recognized microsporidian species that included 215 names [98], and in 1977 he proposed a new microsporidia classification system recognizing 38 genera [95]. Weiser was educated as a parasitologist and his main interest was insect pathology. He published a Czech textbook "Insect Diseases" [99], later translated into Russian [100], which contained a chapter about microsporidia (pp. 384-479) and the "Atlas of Insect Diseases" [101], which contained 143 photos of microsporidia. From 1943 onward, Weiser studied microsporidia in insects (mosquitoes, midges, blackflies and other insectes) and his dissertation on microsporidia [102] was at that time the most comprehensive summary after Kudo's work. He founded the Laboratory of Insect Pathology at the Institute of Biology of the Academy of Sciences in Prague. In 1958 he organized the first international meeting of the new scientific field of insect pathology in Prague (International Conference of Insect Pathology and Biological Control) (Fig. 10). The journal Folia Parasitologica was founded at his request at the Academy in Prague in 1953. With the establishment of the Society for Invertebrate Pa- thology in 1967, he participated in activities and publications of its journal; for example, in the first issue of the journal he published a paper reporting one of the first electron microscopy observations on microsporidia [103] and served as vice president from 1976 to 1978 and as president from 1978 to 1980. He was honoured for his outstanding research on microsporidia through the Rudolf Leuckart-Medaille of the German Society for Parasitology in 1982 and by the Society for Invertebrate Pathology through the Founder's Lecture in 2001, given by Wayne Brooks [104] on his part a pathologist who studied microsporidia and other protozoan infections in insects, and who is best known for his investigations and reviews on host-parasitoid-pathogen interrelationships, particularly of those involving microsporidia [105]. The genus Weiseria Doby \& Saguez, 1964 was created to honour Weiser's work [106]. Today, at age 85 he remains involved in microsporidian research and publishes papers in the field $[47,107]$.

The founding of the Society for Invertebrate Pathology was an important event in microsporidiology. Scientists studying diseases of invertebrates began to meet at international congresses in the 1950s and early 1960s and recog-

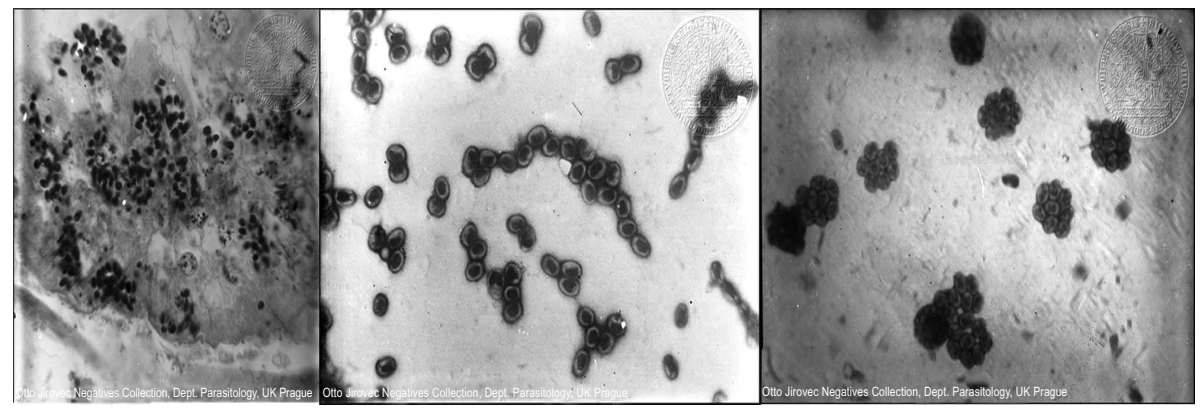

Fig. (9). Nosema apis, Pleistophora stimuli, and Thelohania fibrata spores photographed by Otto Jírovec, from the Otto Jírovec Negatives Collection. Printed with permission, Department of Parasitology, Charles University, Prague, Czech Republic.
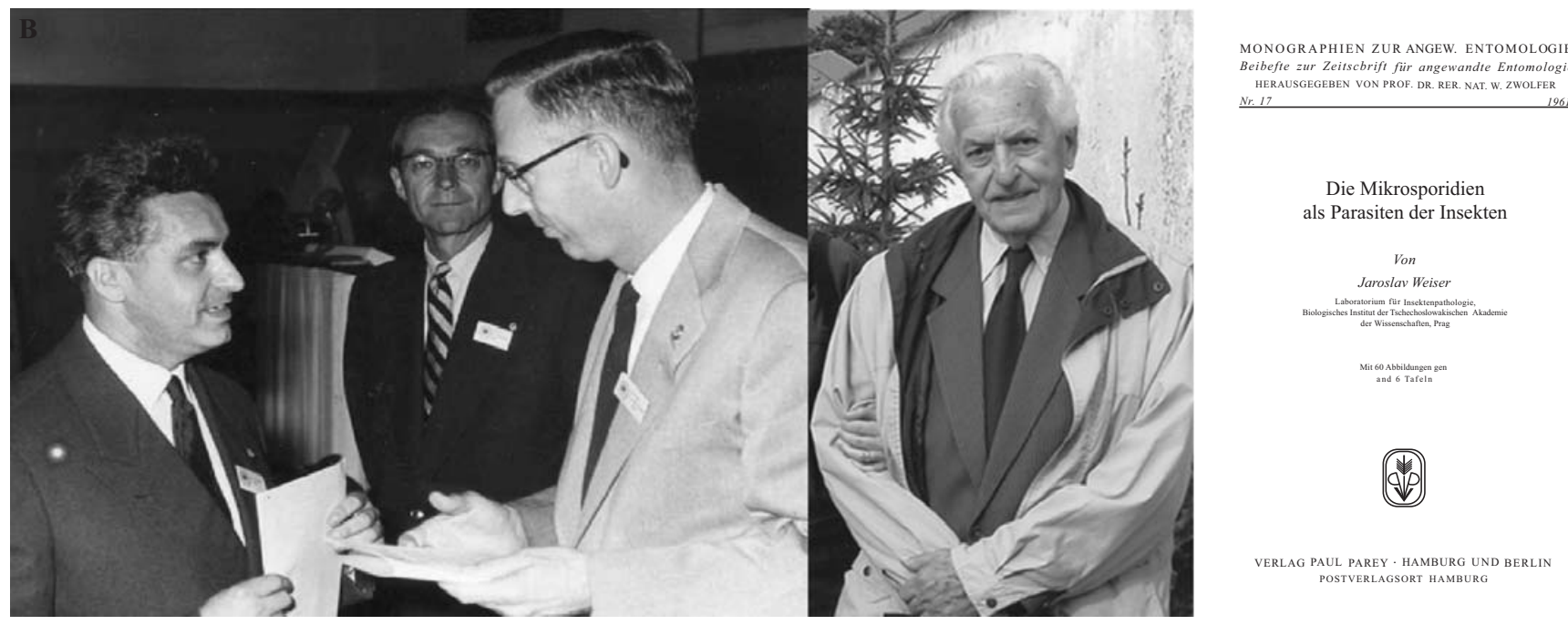

Fig. (10). (a) Jaroslav Weiser (left) and Edward Steinhaus (right), the founding editor of the Journal of Invertebrate Pathology and the first president of the Society for Invertebrate Pathology, at the International Conference of Insect Pathology and Biological Control in Prague 1958. Reprinted with permission from [104]. (b) Jaroslav Weiser at the First United Workshop on Microsporidia from Invertebrate and Vertebrate Hosts in České Budějovice in summer 2004. Photo courtesy of J. Weiser, reprinted with permission from [47]. (c) Monograph on insect microsporidia based Weiser's dissertation, published in 1961, containing 60 figures (photos and line drawings) of microsporidia [108]. 
nized that they needed both a society and a journal. Edward A. Steinhaus (Fig. 10) played a major role in achieving this goal, and in 1959 the Journal of Invertebrate Pathology (then the Journal of Insect Pathology) with Steinhaus as the first editor was initiated. Steinhaus and Albert Sparks also initiated the founding of the Society for Invertebrate Pathology, which was created in 1967 at a meeting in Seattle, and the Division on Microsporidia within the society was organized in 1969. The microsporidian genus Steinhausia Sprague, Ormières \& Manier, 1972 honours Steinhaus for his outstanding work in establishing the field of insect pathology [109]. Much important research on microsporidia has been done by members of the society; in the 1960s, Kellen et al. [110,111] and Alger and Undeen [77] detected microsporidia in wild and caged mosquitoes, Kramer reported on microsporidia in fruit flies [75], and Lipa worked on microsporidia in beetles and other invertebrates [112-115], among several others mentioned later and the society and its journal are still of outstanding importance to microsporidian research [47].

In 1976 and 1977, Vávra and Sprague edited two comprehensive monographs on the microsporidia published in the Comparative Pathobiology book series edited by Bulla and Cheng. This voluminous project was initiated during the First Annual Meeting of the Society for Invertebrate Pathology, held in fall 1968 in Columbus, Ohio, and this summary of the respective state of knowledge combined contributions from more than a dozen specialists. The second part of this monograph contains an encyclopaedic review of the knowledge of microsporidian systematics and an annotated list of species [26, 116]. In this incredible work, Sprague recognized 46 genera (including a collective group) and approximately 725 species (about 200 unnamed) of microsporidia, including information on host, life cycle, morphology, and distribution for each species.

A decade later, Issi published an important taxonomic paper with a new classification of the microsporidia that included 68 genera [117]. In the same year, Elizabeth Canning and Jiří Lom complemented the monographs edited by Bulla and Cheng by focusing on the microsporidia of vertebrates and, for the first time in a major work on the microsporidia, illustrating the text with several photographs of living and fixed specimens [118]. Fourteen years later Canning again, together with Vávra, listed 139 genera in the phylum Microsporidia for the second edition of the Illustrated Guide to the Protozoa [119]. In this chapter an attempt was made to make a census of all microsporidian genera known up to $1999 / 2000$ and each of the genera recognised at the time was briefly described and shown as a drawing or photomicrograph. In her distinguished academic career spanning more than half a century, Elizabeth Canning (Fig. 11) has continuously made important contributions to our knowledge and understanding of the microsporidia. Her interests in Protozoa were broad and covered gregarines, coccidia, malaria parasites, and babesias, but her dominating research interest has been microsporidia. Already her Ph.D. studies at the London School of Hygiene and Tropical Medicine were on microsporidia, leading to the naming of Nosema locustae [120] (recently transferred to the genus Paranosema [121]). This species was later formulated in John Henry's laboratory in Montana, USA, in conjunction with insecticides, for use as a biological control agent $[122,123]$. She has established eight microsporidian genera and 26 species in various invertebrate and vertebrate phyla, and the genus Canningia Weiser, Wegensteiner \& Zizka, 1995 was established to honour her [124]. She was elected as an honorary member of the Society of Protozoologists in 1994. An honorary doctorate of the Universite Blaise Pascal, Clermont Ferrand was conferred on her in 1995. In the last two years, she has received several further honours, including the Purkyne Medal of the Academy of Science of the Czech Republic, the Gold Medal of the Faculty of Sciences of Charles University, Prague, and the Emile Brumpt Prize from the Societe de Pathologie Exotique, Paris, and recently she was honoured by the Society for Invertebrate Pathology through the Founder's Lecture in 2005, given by James Becnel, on his part well known for his studies on microsporidia in various hosts, who, partial with guidance from Sprague and Hazard, described numerous new families, genera and species of microsporidia. Although retired since 1993, Liz Canning is still engaged in microsporidian research and publishes important papers in the field $[125,126]$.

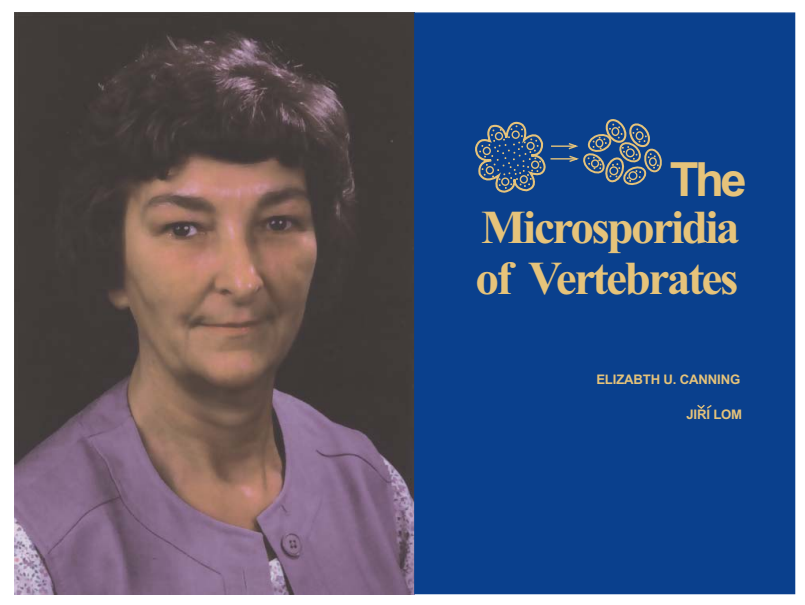

Fig. (11). (a) Elizabeth (Liz) Canning in 1985. Photo courtesy of Elizabeth Canning. (b) Monograph describing the microsporidia of vertebrates published by Canning and Lom in 1986 [118].

In 1999, Murray Wittner - who was a graduate student at Illinois when Kudo was on the faculty and who worked under Kudo - and Louis Weiss edited the last major edition dealing with microsporidia and microsporidiosis. In this edition again Sprague, in the meantime at the age of 90, together with Becnel, listed 143 genera [127]. Victor Sprague (Fig. 12) died in August 2001 at the age of 92. He was Kudo's student at the University of Illinois from 1937 to his graduation in 1940, and a founding member of the Society for Invertebrate Pathology and one of its first trustees. He presented the Founder's Lecture of the society honouring Kudo in 1989 [88] and was elected by the Society of Protozoologists as an honorary member in 1998. He worked for most of his career at the University of Maryland's Chesapeake Bay Biology Laboratory and after Kudo's death he was recognized as the leading expert on microsporidia in the United States for several decades and an outstanding authority on the taxonomy of microsporidia. The genus Spraguea Weissenberg, 1976 was designated to honour him [128]. 


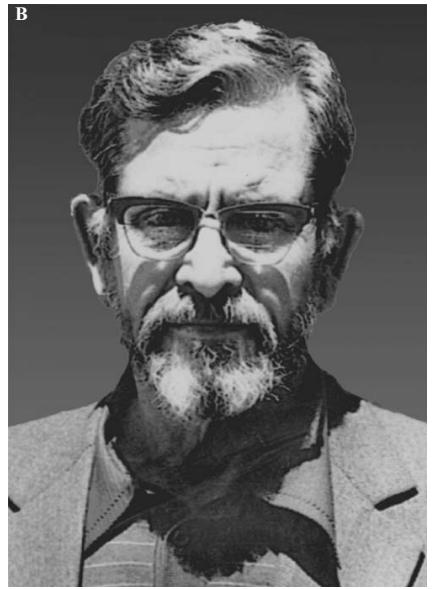

Comparative

Pathobiology

Volume 2

SYSTEMATICS OF

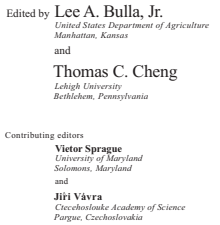

Plenum Press · New York and London
Fig. (12). (a) Victor Sprague (1909-2001). Reprinted with permission from [104]. (b) The monograph, Systematics of the Microsporidia, in which Sprague presents a comprehensive review of the knowledge of microsporidian systematics and an annotated list of species.

The exact number of described microsporidian species is difficult to ascertain, with estimates ranging from 1,000 to 1,500 . This number certainly represents only a small fraction of the total diversity among the microsporidia, and as new hosts are examined the number will surely increase.

Although microsporidia are widely distributed and ubiquitous parasites in invertebrates and in fish and therefore are responsible for considerable infectious disease problems in industries such as fisheries, mink and artic fox farms, or beekeeping, they were largely unknown as causes of human disease before the AIDS pandemic emerged. To date, only seven genera [Enterocytozoon, Encephalitozoon (including Septata), Nosema, Vittaforma, Pleistophora, Trachipleisto- phora, and Anncaliia (formerly Brachiola)], as well as unclassified microsporidial organisms (Microsporidia), have been associated with human diseases. Canning was among the first to suggest the medical importance of the microsporidia [118, 129], and microsporidia are now regularly identified among HIV-infected persons with advanced immunodeficiency as well as in patients with other immunodeficiencies or artificial immunosuppression following organ transplantation.

\section{MORPHOLOGY}

Microsporidia are obligate intracellular, single-celled parasites with a unique ultrastructure and life cycle. The infectious stage of the microsporidia is the spore (Fig. 13).

This spore is the most characteristic form of the microsporidia. Since 1894, when Thélohan first published his observations on the structure of the microsporidian spore [54], numerous researchers have brought forward diverse views about its internal morphology. Microsporidian spores are rather refractile, therefore the internal structure was not revealed before the advent of transmission electron microscopy. Fixed and stained spores show certain structures that had been variously interpreted [90]. Although using light microscopy offered only limited facilities for the study of microsporidia, the most intriguing structure of the microsporidia, which has attracted the attention of parasitologists for a long time, was studied by means of conventional light microscopy. More than 100 years have passed since Thélohan described the microsporidian polar tube and the triggering of its discharge [54], and several other researchers later confirmed this observation on the polar tube extrusion process $[15,89]$. Léger and Hesse in 1916 [42] and Kudo in 1920 [90] already noted that the polar filament was coiled in the spore, and drawings rendered by Kudo showed a spore with an extruded coiled polar tube (Fig. 14a).
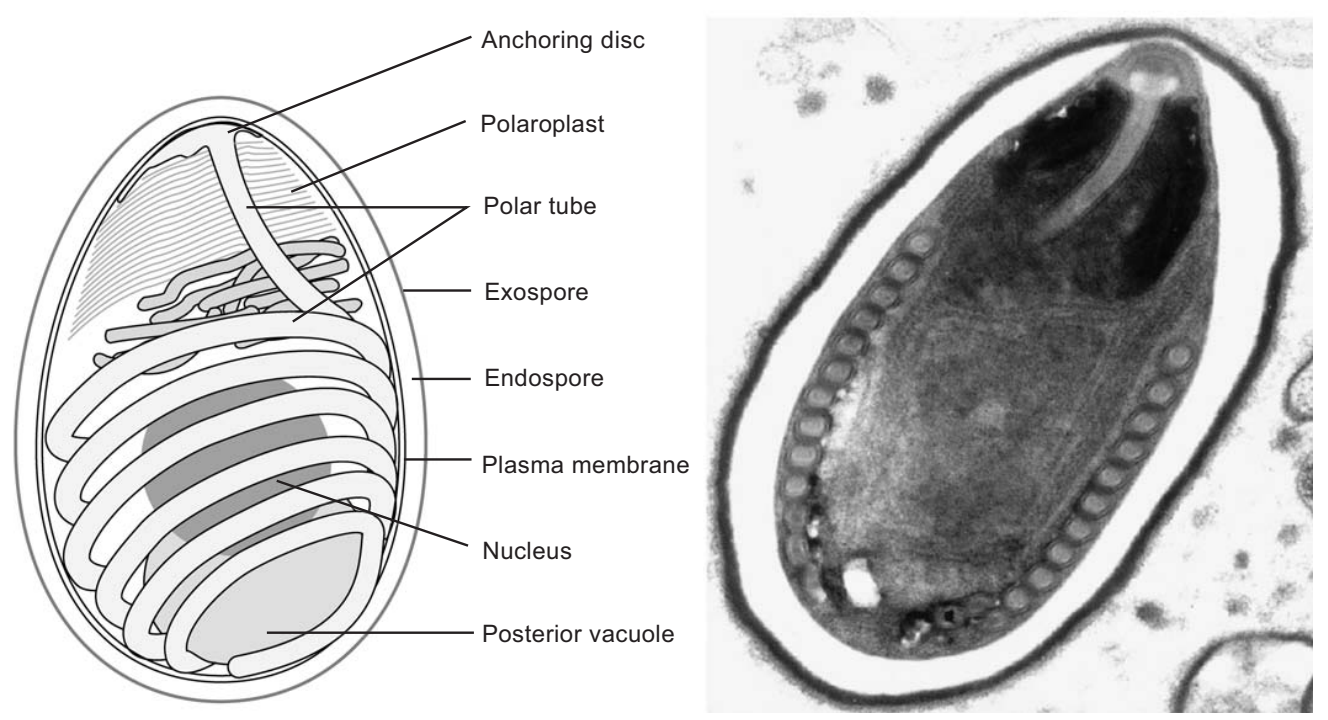

Fig. (13). (a) Diagram and (b) TEM photo of a microsporidian spore. The spore wall is composed of three layers: an electron-dense exospore, a thick electron-lucent endospore, and a plasma membrane. The unique extrusion apparatus inside the spore consists of the coiled polar tube (the number of coils depends on the particular species and varies from a few to 30 or more) that ends at the apical part of the spore in an anchoring disk. Furthermore, inside the spore there are the polaroplast, ribosomes, nucleus, and posterior vacuole. Reprinted with permission from $[130,131]$. 


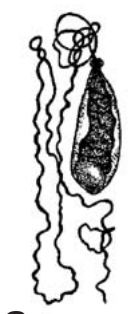

a

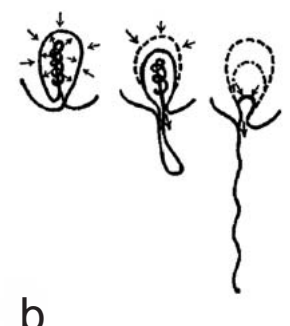

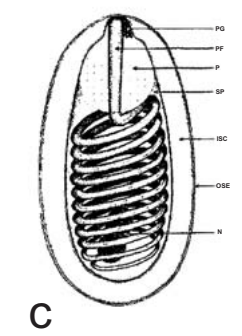

Fig. (14). Early line drawings of microsporidian spores. (a) Spore of Thelohania magna after polar tube discharge. Reprinted with permission from Kudo 1920 [73]. (b) Microsporidian spore with coiled polar filament that is extruded out of the spore. Reprinted with permission from Krieg 1955 [132]. (c) Line drawing of a Nosema locustae spore. Reprinted with permission from Huger 1960 [133]. (d) Diagram of a microsporidian spore from Kudo's Protozoology [86]. Reprinted with permission.

Steinhaus appears to have been the first to employ electron microscopy to study microsporidian spores [134]. This study is largely of historical interest because it did not produce significant new information. Other early studies using electron microscopy were done by Krieg [132]. He interpreted the polar filament as a solid cord and suggested, without electron-microscopic evidence, that the filament was coiled inside the spores in a capsule (Fig. 14b). Weiser in 1959 (in the first issue of the Journal of Invertebrate Pathology) also described a solid polar filament that was coiled irregularly and in unspiraled windings inside the spores [103]. Huger, in 1960, made landmark contributions that resolved several important questions about the structure of microsporidian spores [133]. He recognized the electrondense "outer spore coat", the electron-lucent "inner spore coat", and an internal "surrounding membrane", as well as "the spirally coiled polar filament [that] is embedded in the peripheral region of the sporoplasm". However, he still considered that the polar filament of the spore was not a hollow tube but a solid organelle (Fig. 14c). In 1963, at the end of his academic career, even Kudo published excellent electron microscopy studies showing more clearly than ever before morphological details of microsporidian spores, confirming the tubular structure of the polar filament [91].

Jiř́ Vávra (Fig. 15) made monumental contributions to our knowledge of microsporidian ultrastructure in a short paper published in 1965 (in French), in which he confirmed the unicellular origin of the spore, identified the Golgi apparatus, noted the absence of mitochondria, and demonstrated many other cytological details [134a]. Jiří Vávra was engaged in microsporidian research throughout his academic career. His first papers were published in the 1960s, and after important investigations at the University of Illinois, where he described Nosema algerae (now Anncaliia algerae) [78], he continued his career in Prague, where among other things he described the human-infecting microsporidian species Trachipleistophora anthropophthera [135]. In the 1970s, he and Sprague initiated and edited two comprehensive monographs on the microsporidia to which he contributed important chapters dealing with structure and development of the microsporidia [136, 137], and he summarized terminology and research methods used in the description of microsporidia for the first time [138, 139]. Although he is now retired after more than 50 years of research, Vávra still contributes significant findings to microsporidia research [140- 142a]. The genus Vavraia Weiser, 1977 was designated in his honour [101].

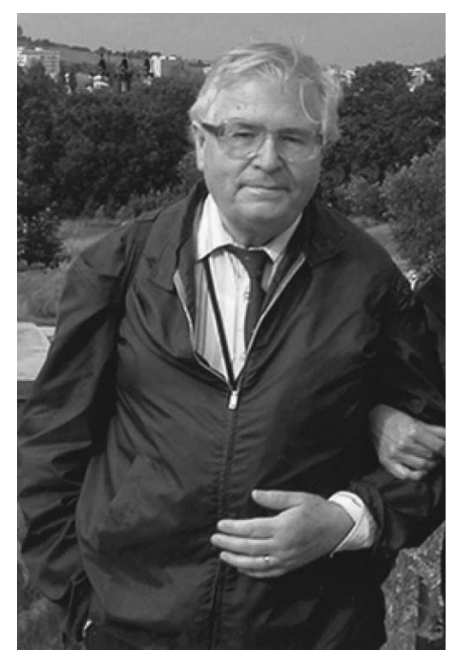

Comparative Pathobiology Volume 1 BIOLOGY OF
THE MICROSPORIDIA

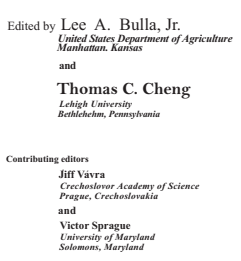

Plenum Press . New York and London

Fig. (15). (a) Jiří Vávra at the First United Workshop on Microsporidia from Invertebrate and Vertebrate Hosts in České Budějovice in summer 2004. Photo courtesy of J. Weiser, reprinted with permission from [47]. (b) The monograph, Biology of the Microsporidia. This summary of the respective state of knowledge combined contributions from more than a dozen specialists and was initiated and edited by Jiří Vávra.

\section{CELL INVASION}

At the beginning of the 19th century, it was generally acknowledged that the polar filament functions to conduct the sporoplasm to a new host cell, and several theories were proposed that involved exit of the sporoplasm from the spore and the function of the polar filament in this process. Originally it was thought that the polar filament was a solid organelle [103, 133, 142], with the sporoplasm attached. Consequently, it was suggested that the filament first extruded as a tightly coiled mass and, as it uncoiled, dragged the sporoplasm out of the spore [132, 142] (Fig. 16).

The tubular nature of the polar filament was first suggested by Morgenthaler in 1922 after observation of the emergence of a fluid mass from the tip of the extruded polar filament of Nosema apis [143]. This observation was later confirmed by Ohshima, who suggested that the sporoplasm from the spores passed through the hollow polar filament 
formed during discharge into epithelial cells in the insect gut (Fig. 17) [144]. Kudo and Daniels finally confirmed the tubular nature of the polar filament [91], and Kramer observed the sporoplasm of a microsporidium passing through an extruded polar tube [74], which was later confirmed by other investigators [145, 146]. In 1962 Lom and Vávra presented the first movie of polar filament extrusion and the sporoplasm passage through the filament at the Colloional sur la Pathologie des Unsectes et la lutte Microbiologique held in Paris in October 1962. This unique process was further investigated by Albert Undeen, who contributed significant findings on the microsporidian polar filament extrusion [8083 ] and by Earl Weidner, who since the 1970s contributed several important papers dealing with the microsporidian polar filament, invasion into cells, and intracellular development of microsporidia [147-153].
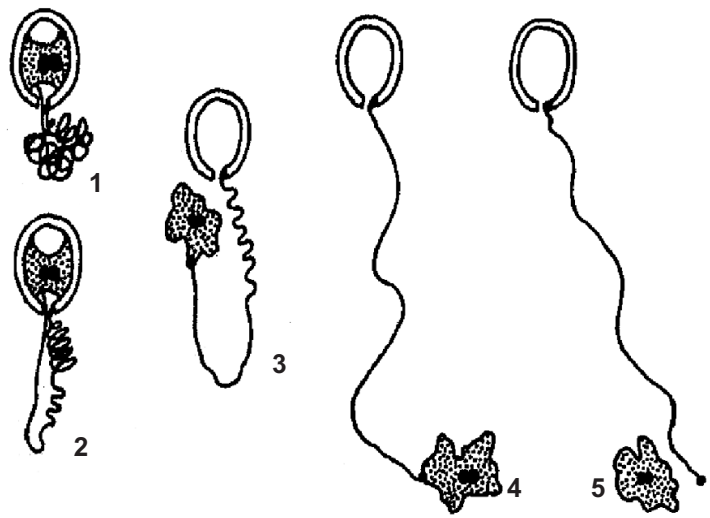

Fig. (16). Early ideas about polar tube discharge. It was suggested that the filament first extruded as a tightly coiled mass and, as it uncoiled, dragged the sporoplasm out of the spore. Reprinted with permission from [142].

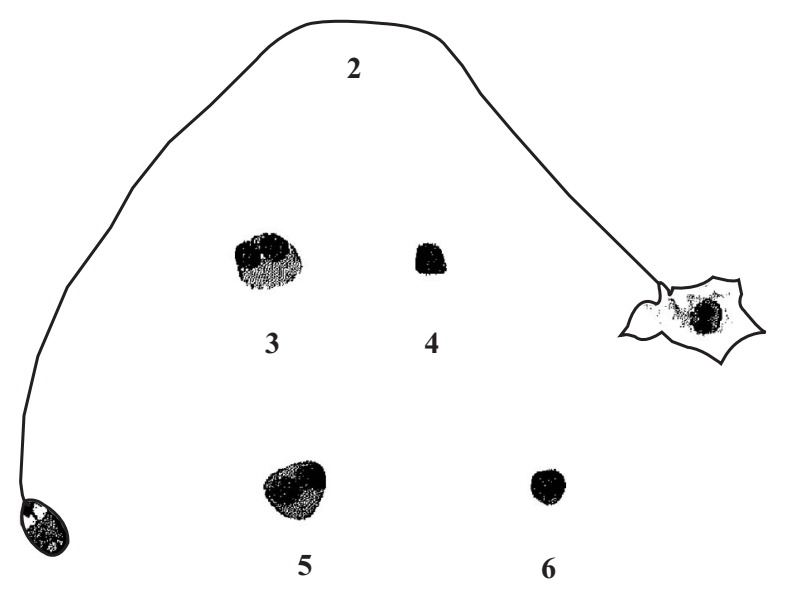

Fig. (17). Spore of Nosema bombycis immediately after germination, as shown by Ohshima 1937 [144]. Reprinted with permission.

Although the polar tube and its discharge were recognized more than 100 years ago and our knowledge about the composition and function of this unique organelle has increased remarkably during the past few years (summarized in $[154,155])$, how the polar tube penetrates the host cell membrane is still unclear. The polar tube has a very narrow diameter $(0.1$ to $0.2 \mu \mathrm{m})$ and is emitted from the spore with considerable force. Initially, it was suggested that the tube pierces the plasma membrane of the new host cell so that the polar tube is used like a hypodermic needle to inject the sporoplasm into the host cytoplasm (Fig. 18).

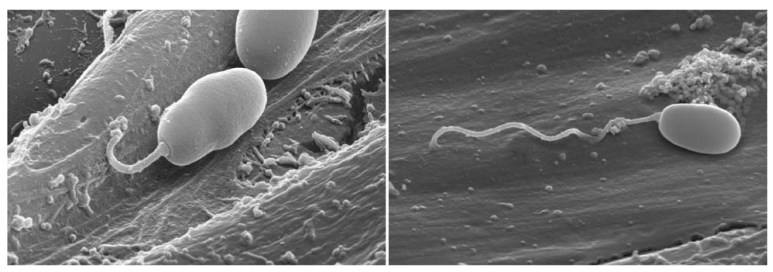

Fig. (18). Microsporidian spores with extruded polar filaments piercing into a cell (reprinted with permission from [156]).

Recent studies using Encephalitozoon spp. have indicated that the polar tube may enter new host cells by a phagocyticlike process without destroying the host cell membrane. The possible development of this penetration process can be seen on transmission and scanning electron micrographs of Encephalitozoon spp., including the invagination tunnel in which a polar tube has penetrated [157-159]. Another scheme has been suggested for the entry of microsporidia $(E$. intestinalis) into non-professional phagocytes (Caco-2 cells), involving specific interaction between the posterior pole of the microsporidian spore and the cellular membrane, extrusion of the polar tube, and induced phagocytosis of the sporoplasm within a host cell membrane-derived vacuole [160]. By contrast, other studies suggest that the phagocytic process occurs on contact of the spore apex with the host cell membrane [159]. However, no evidence for receptormediated endocytosis exists. Thus, polar tube extension may also be an adaptation to allow the non-motile spore to interact with more or less distant target cells. Currently, however, most of these concepts (Fig. 19) remain hypothetical and must be verified because it is difficult to distinguish a polar tube discharging in an invagination of the host cell membrane from a cell engulfing a spore with a previously extruded polar tube.

In addition to the infection of new host cells from outside, there is now considerable evidence that phagocytosis of spores by several cells also occurs [130, 162-164]. Under experimental conditions in cell cultures, many microsporidian spores enter the cytoplasm by internalisation of the spores without discharge of their polar tubes. This uptake could be inhibited by cytochalasin D, suggesting that the entry of spores into the cells is mediated by directed, actindependent phagocytosis. The phagosomes with the internalised microsporidian spores mature to endosomal and then lysosomal compartments, which has been shown by the colocalisation of internalised spores with several endosomal and lysosomal markers inside the cells [130, 162-164]. In previous studies, intracellular microspori-dian spores in vacuoles showed a high capacity for blocking fusion with secondary lysosomes $[152,153]$, but it is important to differentiate between phagosomes harbouring internalised spores that will mature to lysosomes and parasitophorous vacuoles in which the development of the parasites inside the cells 


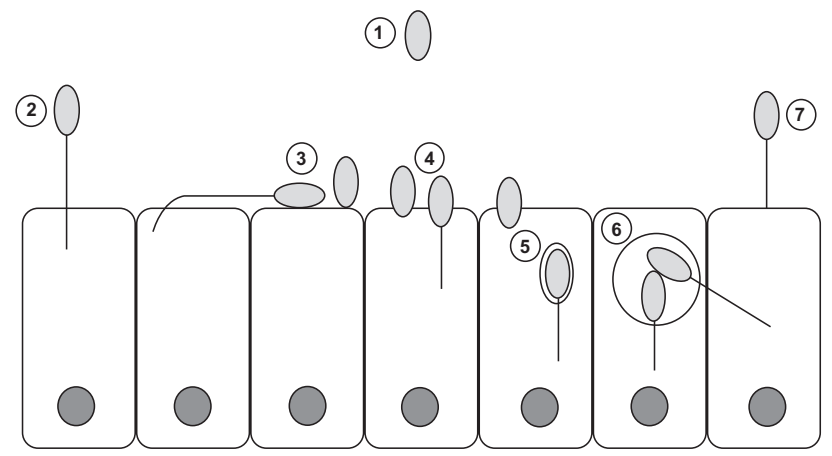

Fig. (19). Hypothetical concepts of cell invasion of microsporidia: 1. Free microsporidian spore; 2. piercing of the host cell membrane by the extruded polar tube and injection of the sporoplasm into the host cell; 3 . interaction between the microsporidian spore and the cellular membrane, extrusion of the polar tube, and induced phagocytosis of the sporoplasm within a host cell membrane-derived vacuole; 4. piercing of the host cell membrane by the extruded polar tube and injection of the sporoplasm into the host cell after interaction between the microsporidian spore and the cellular membrane and initiation of endocytosis of the spore; 5. phagocytosis of the spore and escape of the sporoplasm from the maturing phago-/endo-/lysosome by polar tube discharge; 6 . secondary infection - starting from the parasitophorous vacuole (in the case of Encephalitozoon spp.) or from the cell cytoplasm - of the same or of an adjacent cell through the polar tube; 7. phagocytosis of the previously extruded polar tube. Modified after [161] (reprinted with permission from [162]).

will take place. It has been shown that spores inside the lysosomal compartments are rapidly digested; however, some sporoplasms escape from the maturing lysosomes and infect the cytoplasm of the host cells by polar tube discharge. The sporoplasms of these spores and of spores that inject the polar tube from outside the cells seem to be the only source for the establishment of a new microsporidia life cycle inside the cells. These newly developing parasites are located inside vacuoles as well (in the case of the Encephalitozoon spp.), but these new compartments do not show any markers of late endosomal or lysosomal differentiation. The origin of this parasitophorous vacuole is still unclear (Fig. 20). Similar concepts have been suggested earlier in previous stuides [108, 165], but experimental evidence was only achieved recently [130, 162-164].

\section{LIFE CYCLES}

The early researchers (Lebert, Leydig, Nägeli, Pasteur) only described spores, and Balbiani was the first to try to construe a life cycle, based on his infectivity studies [14]. Pfeiffer [24] and Thélohan [53-55] performed further research on the life cycle of the microsporidia, but Stempell [15, 58, 59], Weissenberg [64], Fantham and Porter [34, 35], Mercier [51, 52], and Debaisieux [48-50] (among others) described some microsporidian life cycles in more detail for the first time. Microsporidia have no active stages outside their host cells, and they can survive only by living inside other cells. The general life cycle pattern of the microsporidia, although there is fundamental diversity, can be divided into three phases that were already described by the researchers mentioned above: the infective phase (described (a)
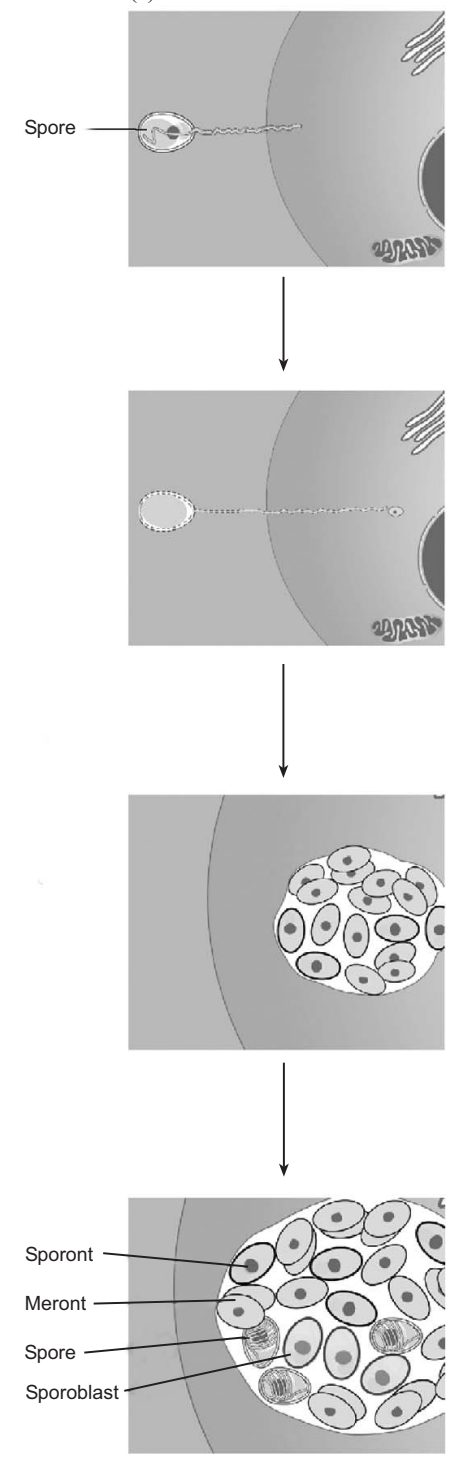

(b)
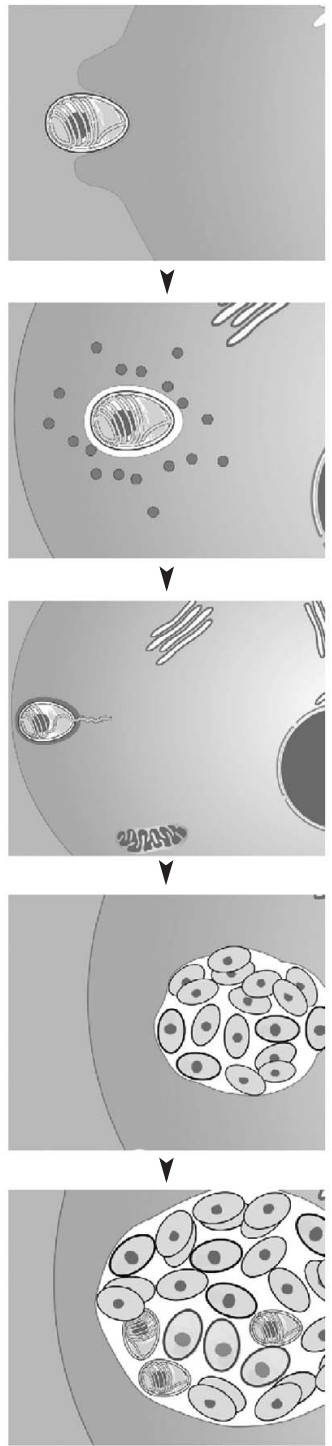

Fig. (20). Experimental evidence exists for two mechanisms for microsporidia invasion of cells. (a) With appropriate conditions, the polar tube is discharged through the anterior end of the spore, thus penetrating a new host cell and inoculating the infective sporoplasm into the new host cell. Inside the host cells, the sporoplasms released from the spores mature into meronts that are surrounded by a parasitophorous vacuole (in the case of the Encephalitozoon spp.). Meronts reproduce by binary fission and finally develop into sporonts, which are characterized by the appearance of a dense surface coat. Sporonts divide into sporoblasts, which will finally develop into mature spores (sporogony). New spores are released from the parasitophorous vacuole and from the host cell. (b) The second mechanism by which the spore enters the host cell: There is clear evidence that microsporidian spores gain access to new host cells by endocytosis, as well. Spores are phagocytosed by the cell, and the phagosomes with the phagocytosed spores matures into lysosomes. Sporoplasms can escape from the maturing lysosomes and infect cell cytoplasm by polar tube discharge. Inside the host cells, sporoplasms released from the spores mature into meronts and development will take place as described above (reprinted with permission from [130]). 
above in the Cell Invasion section), the proliferative phase (merogony), and the spore productive phase (sporogony).

Once inside a cell, the sporoplasm released from the polar tube initiates the proliferative phase of development called merogony. In suitable cells the sporoplasms become meronts, which are rounded or irregular, sometimeselongated cells with little or even no endoplasmic reticulum. They are surrounded by a simple plasma membrane and proliferate by repeated binary or multiple fission or by plasmotomy [118]. They may contain one or more nuclei, and when more nuclei are present they may be isolated or are in a diplokaryotic arrangement (Fig. 21). Ann Cali was the first to show via ultrastructural examinations that such diplokarya are characteristic for the genus Nosema, and consequently she separated the genus Encephalitozoon from the genus Nosema [166]. Division of meronts occurs either by binary fission (e.g., Encephalitozoon, Nosema, Thelohania, and Vittaforma), or karyokinesis may occur before delayed cytokinesis, resulting in multinucleated forms called merogonial plasmodia (e.g., Enterocytozoon, Pleistophora, and Trachipleistophora).

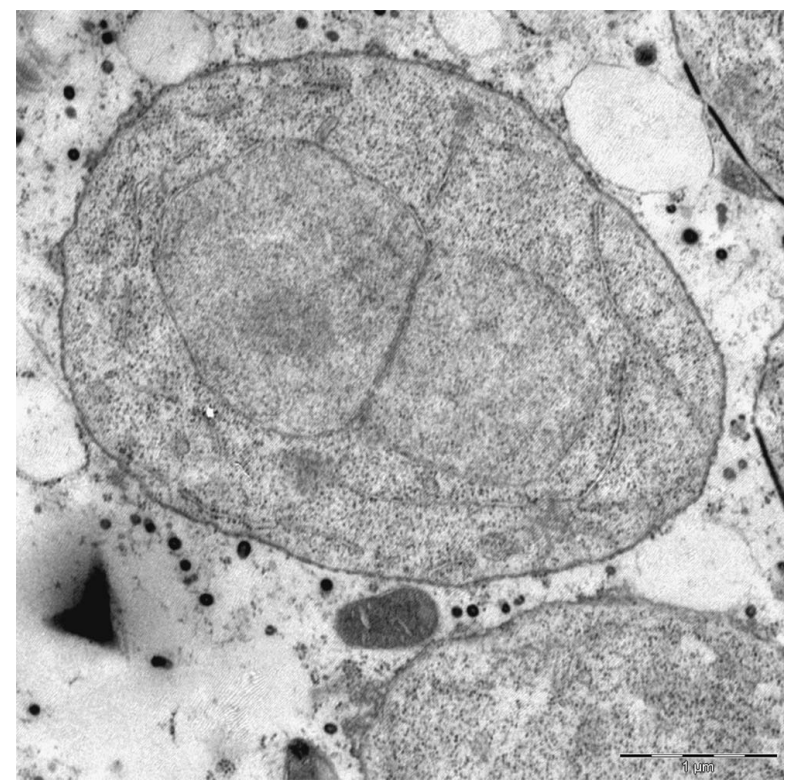

Fig. (21). Meront of Tubulinosema kingi with a clearly visible diplokaryon (reprinted with permission from [167]).

Meronts develop into sporonts, which is the stage that divides into sporoblasts. Sporonts are usually characterized by the development of a thick, electron-dense surface coat that will later become the exospore layer of the spore wall (Fig. 22). As in meronts, the nuclei of sporonts may be isolated or paired. Sporonts develop directly into sporoblasts by binary fission (disporoblastic sporogony) or become multinucleated plasmodia and pass through a two-phased or sequential series of divisions. The division sequences are quite variable and highly characteristic for each genus.

Sporoblasts are generally ovoid bodies that at the electron microscope level often are shrunken, leading to a starlike form of the cells (Fig. 23). They mature into spores by the synthesis of spore organelles. Smooth and rough endoplasmic reticulum increases and produces Golgi-like vesicles that appear to generate the polar filament, and the electronlucent endospore develops beneath the outer electron-dense exospore.

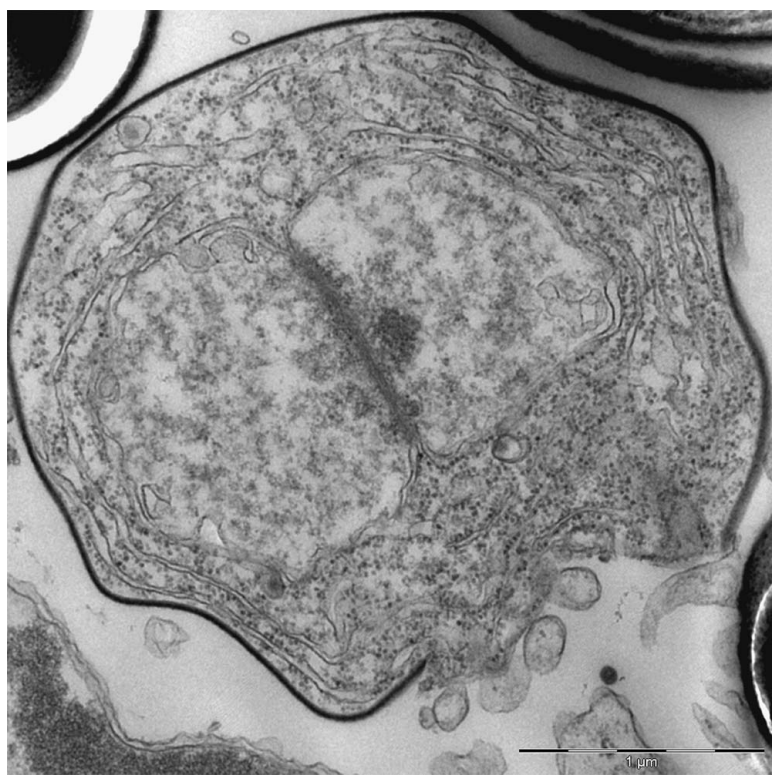

Fig. (22). Sporont of Tubulinosema ratisbonensis with a diplokaryon and thickened plasma membrane (reprinted with permission from [168]).

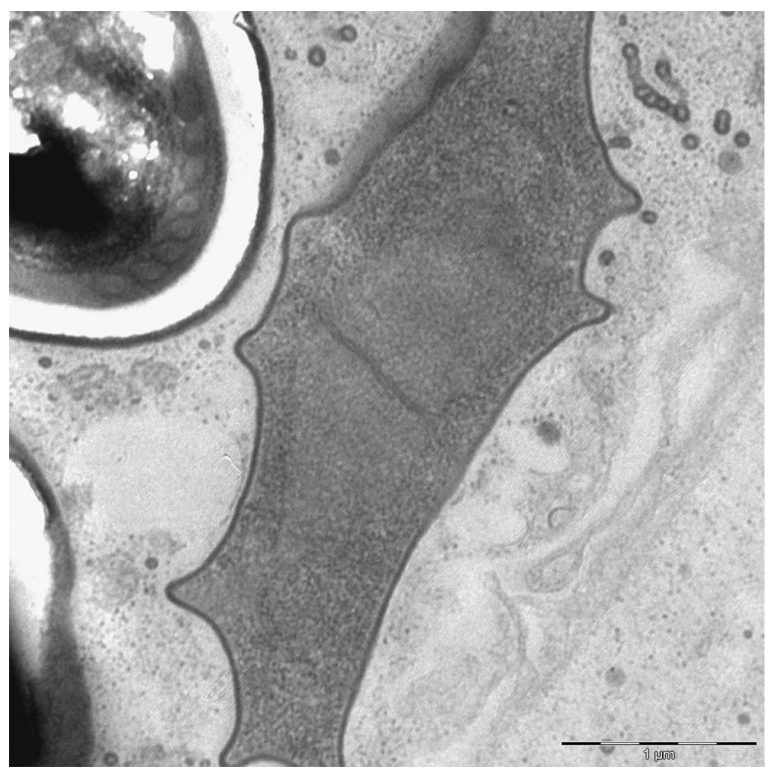

Fig. (23). Sporont of Tubulinosma kingi. Such star-like formations are caused by shrinkage during fixation for electron microscopy (reprinted with permission from [167]).

During the intracellular part of the life cycle (merogony and sporogony), the microsporidia lie either in direct contact with the host cell cytoplasm (Figs. 21-24), or some genera show specialisations at the interface with the host cell cytoplasm. For example, Encephalitozoon spp. are surrounded by a parasitophorous vacuole (which is believed to be of host cell origin), but Pleistophora spp. develop inside a sporophorous vesicle (which is believed to be a parasite-derived envelope) (Fig. 24). Cali and Takvorian [169] distinguished four types of interfacial relationships: Type I represents species that develop in direct contact with the host cell cytoplasm 
(e.g., Nosema and Enterocytozoon). Type II represents species that are isolated inside the cell by host-produced structures. To this group belong the parasitophorous vacuole of the Encephalitozoon spp. and a host double membrane of endoplasmic reticulum that surrounds the parasites (e.g., Endoreticulatus). Type III represents species that are isolated inside the cell by parasite-produced structures such as sporophorous vesicles (e.g. Pleistophora). Type IV represents species that are separated from the host cell cytoplasm by both host- and parasite-produced structures. Loma and Glugea are first surrounded by host endoplasmic reticulum during merogony, and later a sporophorous vesicle is formed during sporogony. In other species, the host cell and parasite contribute to the formation of the interfacial envelope (e.g., Trachipleistophora) [169].

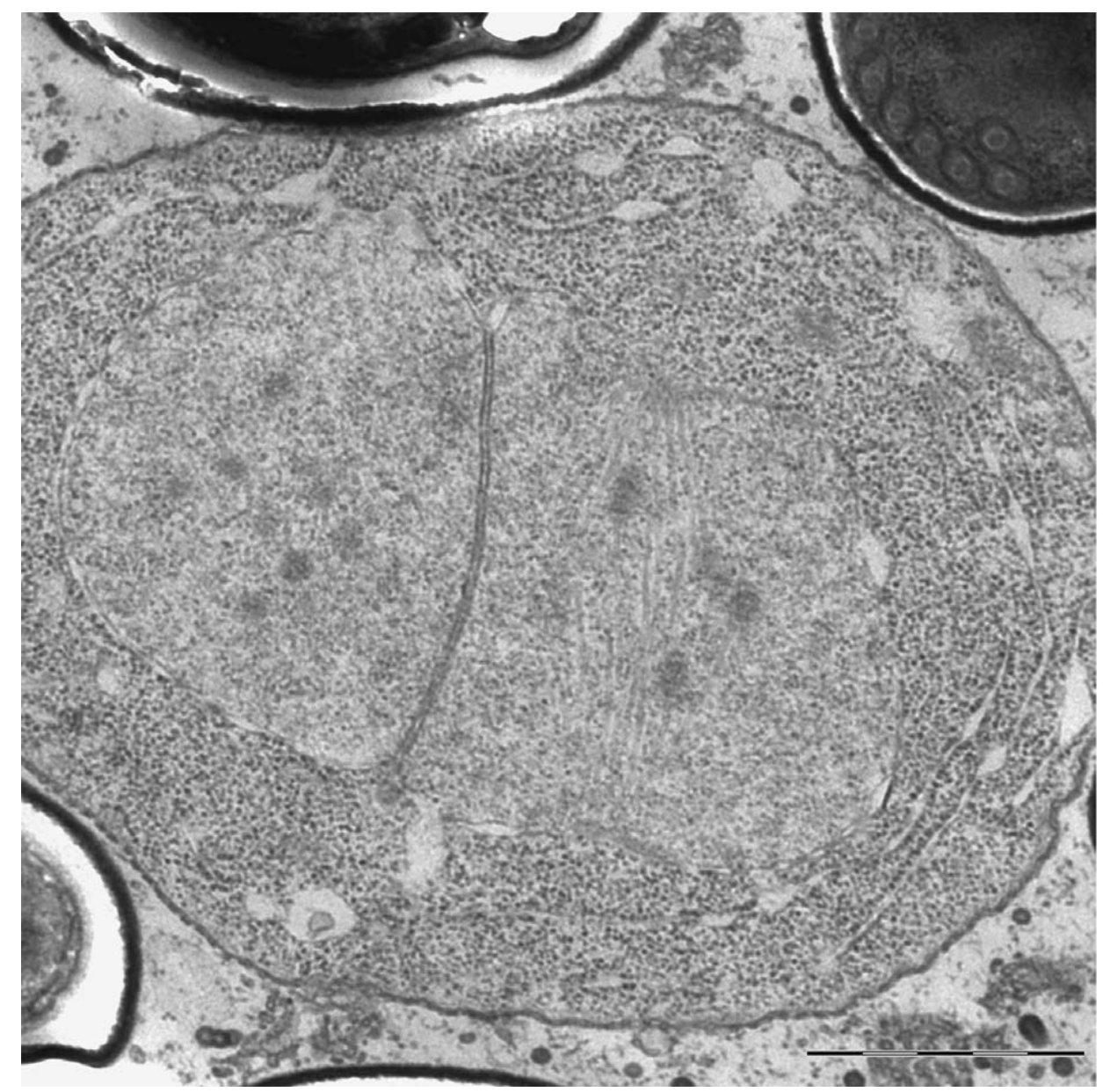

Fig. (24). Diagram of the life cycle of two human microsporidian genera that develop in direct contact with the host cell cytoplasm (Enterocytozoon bieneusi) or inside a parasitophorous vacuole (Encephalitozoon spp.). (A) An empty spore with its polar tube extruded and a sporoplasm at the end injected into the host cell cytoplasm. (B1 to D1) Intracellular development of E. bieneusi in direct contact with the host cell cytoplasm. (B1) Proliferative merogonial plasmodia; (C1) sporogonial plasmodia. (D1) During sporogony the plasma membrane thickens and invaginates, separating individual nuclei with polar tubule complexes to form sporoblasts that mature into spores (E1). (B2 to D2) Development of Encephalitozoon spp. takes place in a parasitophorous vacuole in the host cell cytoplasm. (B2) Merogonial plasmodia that multiply by binary or multiple fission. (C2) Merogonial plasmodia with thin plasma membrane, sporogonial plasmodia with thickened plasma membrane, sporoblast spores. (D2) Parasitophorous vacuole filled with spores that will be liberated after rupture of the membrane (E2). (a to e) Transmission electron micrographs of different life cycle stages of E. bieneusi (a1 to e1) and Encephalitozoon cuniculi (a2 to e2). (a1) Spore of E. bieneusi with a thin exospore, thick endospore, and coiled polar filament forming two rows. (b1) Multinucleate merogonial plasmodium with typical clefts. (c1) Formation of extrusion apparatus elements in sporogonial plasmodium. (d1) Sporoblast with polar filament coils. (e1) Infected enterocyte with spores is released into the intestine lumen. (a2) Spore of E. cuniculi with thin exospore, thick endospore, and six coils of the polar tube arranged in one row. (b2) Parasitophorous vacuole of E. cuniculi with two uninucleate merogonial plasmodia (thin plasma membrane) and sporogonial plasmodia with thick plasma membrane. (c2) Parasitophorous vacuole of E. cuniculi with merogonial and sporogonial plasmodia and spores. (d2) Parasitophorous vacuole with spores of E. cuniculi. (e2) Spore of E. cuniculi. 
Simple life cycles are completed in a single host (e.g., for mammalian microsporidia, see Fig. 24), whereas complex cycles require different hosts with involvement of more than one generation of the parasite with different morphologies. Dimorphism of microsporidia was first suggested by Maddox in his Ph.D. thesis, who suspected that Nosema necatrix and Thelohania diazoma in the armyworm Pseudaletia unipunctata [76] represented two stages of the same parasite [79]. This was later confirmed by Fowler and Reeves, who used for the first time protein profiles created by electrophoresis to differentiate among microsporidian species [170, 171]. These findings later led to the creation of the new genus Vairimorpha with the type species Vairimorpha necatrix [172]. In the meantime, Hazard and Weiser in 1968 were the first to find that some microsporidia in mosquito hosts ( $\mathrm{Am}$ blyospora, Parathelohania) have both Thelohania-like and Nosema-like sporulation sequences, demonstrating that the two morphologically distinctive spores found in the respective host stages represented a single species [173]. Thereafter, numerous further heterosporous species have been detected in other genera, e.g., Amblyospora [174] and Burenella [175]. In 1985 Hazard (in cooperation with Sweeney and Graham from Australia) [176] and, independently, Andreadis [177] demonstrated that some Amblyospora spp. not only have two sporulation sequences in the mosquito host but a third one in an intermediate, copepod host that is required to complete the life cycle. Hazard's research had important taxonomic implications because to this point, many microsporidian genera and species, particularly in insects, had been described only on the basis of spore type and descriptions of one sporulation sequence, without any information about transmission. But after the descriptions of heterosporous species, the primordial dogma "one spore-one species" was questioned by Hazard and Weiser [173].

Edwin Hazard (Fig. 25) was with the U.S. Department of Agriculture's (USDA's) Insects Affecting Man and Animal Laboratory at Gainesville, Florida from 1963 to 1981 and thereafter served as research leader of the microsporidia project at the USDA's Gulf Coast Mosquito Research Laboratory at Lake Charles, Louisiana. He was engaged in several biological control studies of vector insects and developed a laboratory method to mass produce Anncaliia algerae (then Nosema algerae) in larvae of the family Noctuidae (together with J. Weiser based on his experience with Barathra brassicae as substitute host [178]) for use in field studies against mosquitoes in lagoons in the Panama Canal Zone [179]. In addition to the significant contributions mentioned above, he published important papers on the taxonomy of microsporidia of the family Thelohaniidae, helping to establish the necessity of using electron microscopy to distinguish microsporidian taxa and the importance of ultrastructural features in microsporidian systematics $[27,174,180]$. Because of his sudden death in 1985, much of his work remains uncompleted, especially his effort to develop a more natural system of classification of the microsporidia [181]. The genera Hazardia Weiser, 1977 and Edhazardia Becnel, Sprague \& Fukuda, 1989 were created to honour him [95, 182].

Finally, in the 1990s it was discovered that some species of the genera Nosema, Vairimorpha, and Edhazardia produced previously unknown binucleate spores that functioned in the spread of infection to other tissues [183-187]. New detection of currently unrecognized sporulation sequences in other genera of microsporidia will have further impact on the taxonomy of the microsporidia.

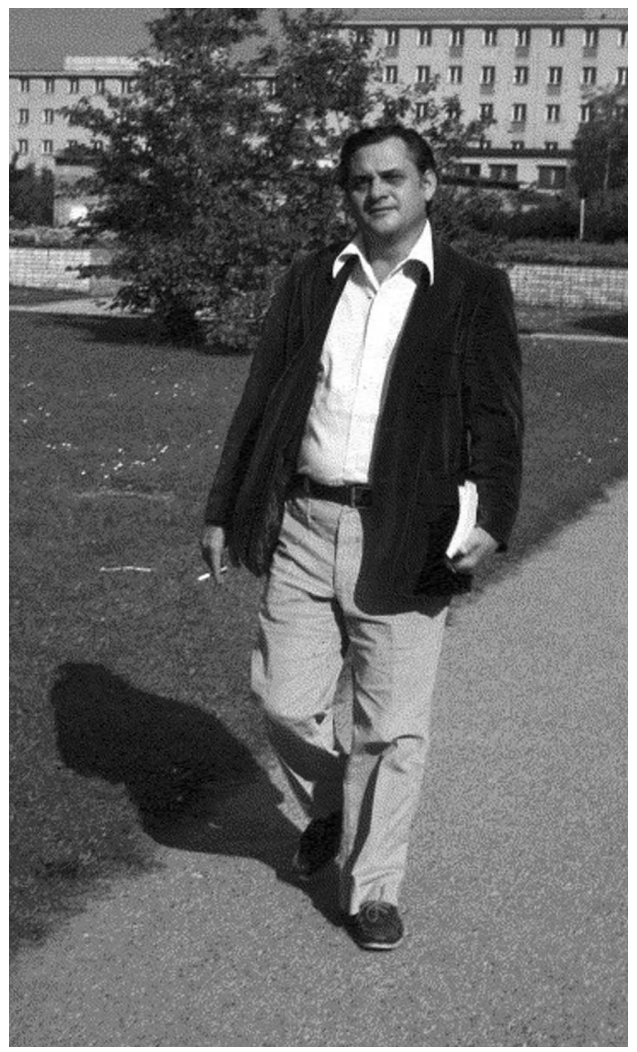

Fig. (25). Edwin Hazard (1935-1985) (photo courtesy of J Weiser, reprinted with permission from [47]).

\section{TAXONOMY AND PHYLOGENY}

Microsporidia are ranked as a separate phylum, Microsporidia, in the kingdom Protista, meaning that they are eukaryotic and unicellular. The unique structure of the microsporidian spore separates the phylum Microsporidia from other protists and indicates that the microsporidia constitute a monophyletic taxon with no evident relationship to other protists.

Originally considered to be ancient organisms evolutionary placed as an early branch leading from prokaryotes to eukaryotes, new evidence favours a more recent origin of the microsporidia, suggesting that they are a part of the crown of eukaryotes that have lost several genes and have undergone considerable gene compaction, probably in response to their growing adaptation to intracellular parasitism [188].

In 1968, Ishihara and Hayashi showed by using sucrose density-gradient centrifugation techniques that the ribosomes and their two subunits of $N$. bombycis have density coefficients like those of the prokaryote Escherichia coli and that the RNA content of the Nosema ribosomes is $60 \%$ like that of E. coli, rather than 50\% as in other eukaryotes [189]. This startling discovery was later confirmed by Curgy, Vávra and Vivarès, who demonstrated that the two main RNA molecules extracted from the ribosomes of some microsporidia have electrophoretic coefficients identical to those of pro- 
karyotes [190]. They pointed out that similar results had been found in Coccidia and speculated that this situation may relate to the endoparasitic way of life. This question was not further investigated until molecular techniques became available, and in microsporidia the molecular approach was pioneered by Charles Vossbrinck. In 1986 Vossbrinck and Woese found by sequencing that ribosomes of the microsporidium Vairimorpha necatrix lack the 5.8S RNA subunit that was thought to be a universal eukaryotic characteristic [191]. One year later, Vossbrinck et al. used molecular sequencing methods with $V$. necatrix to show the phylogenetic position of microsporidia on the tree of life [192]. After comparing ribosomal sequence data of the microsporidium with already available data from protozoa, plants, animals, and fungi, they found that microsporidia diverged from other eukaryotes before the evolution of the mitochondria. Subsequent analyses on the basis of the SSU rRNA of Vairimorpha and several other microsporidia and using different methods of tree construction all supported the view that microsporidia were an early-diverging and therefore presumably extremely old lineage. This hypothesis was also supported by phylogenetic analysis of other proteins of the translational apparatus (translation elongation factors EF1a and EF-2, glutamyl tRNA synthase) [193].

One additional reason behind the proposal that microsporidia are ancient eukaryotes was their lack of mitochondria [194]. Because microsporidian genomes contain proteins of mitochondrial descent [including mitochondrial heat shock protein (HSP) 70] related to some mitochondrial functions (e.g., iron-sulphur [Fe-S] cluster assembly) [195198], it was hypothesized that microsporidia have retained a mitochondrial-derived organelle (mitosome), which has been detected by immunohistochemical staining [199]. Vávra recently identified double-membrane vesicles in Vavraia culicis, Amblyospora sp., Vairimorpha sp., and Marssoniella elegans and proposed that these polar vesicles were those mitochondrial remnants (mitosomes) [141].

Whereas microsporidian small subunit rRNA gene sequences were found to more closely resemble those of prokaryotes than eukaryotes, suggesting that microsporidia were ancient eukaryotes, phylogenetic analyses of gene sequences for $\alpha$ - and $\beta$-tubulin and for the largest subunit of RNA polymerase II, the TATA-boxbinding protein, and mitochondrial HSP70 supported a closer relationship between microsporidia and fungi [196, 200, 201]. This discrepancy may be explained by the long-branch attraction artefact of many phylogenetic methods which leads to erroneously grouping fast-evolving lineages at the base of the tree when they are analyzed together with other slowly evolving lineages [202].

Although microsporidia lack some typical eukaryotic characteristics (rRNA of prokaryotic size without separate 5.8S rRNA and ribosomes resemble the ribosomes of prokaryotic organisms; typical mitochondria, peroxisomes, and a classical Golgi apparatus are missing), they are true eukaryotes with a nucleus and an intracytoplasmatic membrane system, and they undergo chromosome separation by mitotic spindles (see Fig. 26) and even though molecular data indicate fungal affinities, these give no indication of a new systematic position [203]. A new designation of the microsporidia would produce several administrative problems concerning funding programs, institutes in which microsporidia are studied, and decisions about museum and/or collection deposition [47]. However, at the present time there is no fungal taxon in which microsporidia might be ranked, and at a recent Conference in České Budějovice, Czech Republic in July 2004 (First United Workshop on Microsporidia from Invertebrate and Vertebrate Hosts), it was the opinion of the gathered experts that the names and type material of new species should follow the rules of the International Code of Zoological Nomenclature [203]. Yet it seems that 150 years after Nägeli's initial placing of Nosema bombycis among the fungi, this original taxonomic designation may be borne out [8].

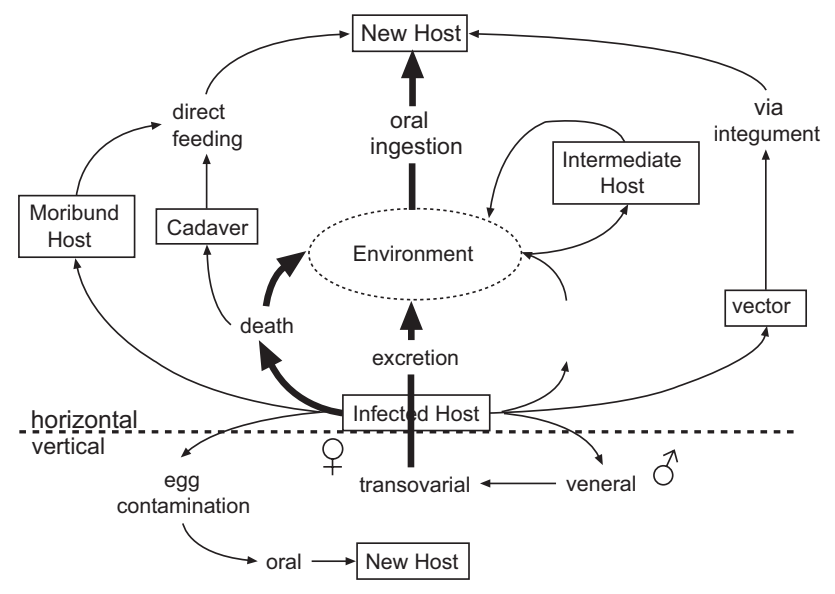

Fig. (26). Meront of Tubulinosema kingi undergoing karyogenesis. A mitotic spindle can be seen in the right nucleus. (reprinted with permission from [167]).

Historical classification systems of the microsporidia have been produced on the basis of simple morphologic characters [203]. The modes of spore formation, in particular the number of spores produced by each sporoblast, were used in the first attempts by Thélohan, Doflein, and Pérez to classify the microsporidia [53, 55, 56, 67]. Oddly enough, Thélohan, although working in the laboratory of Balbiani, did not use the term microsporidia, which Balbiani previously proposed. Stempell later concluded that a microsporidian classification system could be produced only when the form and development of vegetative forms, the mode of spore formation, and the form of spores were considered as the characters of family, genus, and species respectively [15]. Léger and Hesse used mainly spore shape and structure as important morphological characters in their classification [46]. Kudo believed that the "system of Léger and Hesse is best fitted to the present state of knowledge on Microsporidia", and he followed this system in his monograph "with slight modifications" [73].

However, the taxonomy of microsporidia remains controversial because all subsequently published classifications differ significantly, and microsporidian taxonomy is cur- 
rently under extensive reconstruction. Particularly, the higher-level classification of the microsporidia has been tenuous because the significance of the homology among the morphological characters that could be identified could not be determined. The split of the microsporidia into classes has been based on characters such as whether there is a membrane surrounding the sporoblast (Pansporoblastina versus Apansporoblastina) [26, 204], whether they are diplokaryotic throughout their life cycle or have uninucleate states [95], and the type of nuclear division (Haplophasea versus Dihaplophasea) [27].

Weiser [95] listed 70 characters for the identification of microsporidia, which can be distinguished by light microscopy. After electron microscopy was introduced for taxonomic purposes in the mid 1970 s, other important contributions to the identification of microsporidian genera were presented by Issi [117] and Larsson [205, 206]. Issi [117] listed 11 light- and electron-microscopic visible characters for 68 microsporidian genera. The phylogentic tree proposed in her contribution places for the first time Vairimorpha close to Nosema, which is in perfect agreement with later molecular phylogenetic analysis [207]. Irma Issi, who is head of the research group on microsporidia in St. Petersburg in Russia, studied microsporidia from the early 1960s, when she investigated microsporidiosis of Pieris brassicae in the laboratory of Microbiological Control of the All-Russian Institute of Plant Protection in St. Petersburg. She has described many new microsporidian species and identified several new genera, thus contributed significantly to microsporidian taxonomy, and remains engaged in microsporidian research today [208, 209]. The genus Issia Weiser, 1977 was named in her honour [95].

Issi's important taxonomic paper was written in the Russian language and therefore for many researchers is not easy to use. Fortunately, a complete English translation of this contribution was made by Lipa for the Division on Microsporidia of the Society for Invertebrate Pathology. Jerzy J. Lipa from the Institute of Plant Protection in Poznan, Poland, who was a postgraduate student of Steinhaus, has been engaged in microsporidian research since the 1950s and in addition to the important translation of Issi's work, he contributed several important papers of his own on microsporidia in insects [112-115, 210].

Larsson [205] presented a similar chart with 11 characters describing 66 microsporidian species from 51 genera and two years later produced a further identification key, including several light and electron microscopical characters for the available microsporidian genera. Ronny Larsson's interest in microsporidia was, among other influences, initiated by Weiser. In 1977 Weiser was invited to give a seminar on insect pathology at Lund University in Sweden, but Larsson, at that time a young zoologist, asked him to speak only on microsporidia [47]. Subsequently, he began his important taxonomic studies on microsporidia during which he described several new genera and species, and he published important papers and monographs [140, 205, 206]. The genera Larssonia Vidtman \& Sokolova, 1994 and Larssoniella Weiser \& David, 1997 were created to honour him [211, 212].
There is increasing evidence that, while there are correlations in some cases between the traditionally used characters and phylogenetic relatedness, these taxonomic schemes have almost no relationship to evolutionary history because these characters change relatively rapidly as evolutionary adaptations to host, host environment, and host population parameters occur. As a result, higher-level classifications based on these characters are probably not measures of evolutionary relatedness and indeed vary greatly among classification systems.

Molecular techniques are rapidly becoming an important and integral part of biosystematic studies. Microsporidia are prime candidates for phylogenetic analysis based on DNA sequence data because of the relatively small number of useful morphological characters.

The first complete genome sequence of a microsporidian species, Encephalitozoon cuniculi, was published in 2001 [198] (http://www.genoscope.cns.fr/externe/English/Projets/ Projet_AD/AD.html). This important work was initiated by Christian Vivarès of the Laboratoire de Protistologie Moléculaire et Cellulaire des Parasites Opportunistes of the Université Blaise Pascal in Aubière, France, who has been studying microsporidia since the 1970 s, and was carried out by Genoscope (the French National Sequencing Center). E. cuniculi has a very compact genome (one of the smallest eukaryotic genomes known to date) of 2.9 Mbases organized into 11 chromosomes. A genome sequence survey on a second microsporidian species, Paranosema locustae (called Antonospora locustae by Patrick Keeling and his team, who have done this research [213]), has been completed recently [214, 215] http://www.botany.ubc.ca/keeling/Antonospora GSS.html). Several further genome sequence surveys are currently under way, including those on Anncaliia algerae (http://www. genoscope.cns.fr/externe/English/Projets/ Projet_KI/KI.html), Spraguea lophii [216] (http://jbpc.mbl.edu/ Spraguea-HTML/), N. bombycis, Vittaforma corneae [217], Enterocytozoon bieneusi, Encephalitozoon hellem, and Edhazardia aedis (203) and an expressed sequence tag survey for $P$. locustae (http://amoebidia.bcm.umontreal.ca/ public/pepdb/agrm.php) [203, 214].

Phylogenies based on molecular sequence data are helping to resolve a large number of questions about the evolution of characters in the microsporidia. Most of these studies use sequence data from the small subunit rDNA. This is because a large number of sequences have become available for this gene and it has become somewhat of a standard; however, other genes will have to be sequenced to confirm and further clarify microsporidial relationships. Again Vossbrinck et al. was the first who used comparative analysis of rRNA sequence data to present an unrooted tree of five microsporidian species from a phylogenetic analysis. [216a] Another early study published by Baker (a graduate student of Vossbrinck) et al. showed that $N$. bombycis and the Vairimorpha spp. were closely related [207]. In traditional classification schemes of that time, these species were divided into distantly related taxa (with the exception of Issi's system from 1986 [117]) because N. bombycis is diplokaryotic throughout its life cycle whereas Vairimorpha spp. produces both isolated diplokaryotic spores and uninucleate octospores in packets surrounded by a pansporoblastic mem- 
brane. As both microsporidia are parasites of Lepidoptera, this analysis highlights the importance of the host as an important taxonomic character that, however, may not be valid for all genera [208]. This analysis and other studies [131] further indicated that some Nosema and Vairimorpha spp. are consistently grouped together with the type species $N$. bombycis, whereas other Nosema spp. form clades of their own containing, for example, Nosema algerae, Nosema locustae, Nosema kingi, and Nosema acridophagus [131, 168, 207]. It has been concluded that some characteristics of the genus Nosema (e.g., being diplokaryotic throughout the life cycle) have evolved more than once and that the genus Nosema is a polyphyletic collection of microsporidia [26, 207]. Subsequently, several of these unrelated Nosema spp., including Nosema algerae (=Anncaliia algerae), Nosema connori (=A. connori) [208], Nosema corneum (=Vittaforma corneae) [217a], Nosema locustae (=Paranosema locustae), Nosema grylli $(=P$. grylli), Nosema whitei $(=P$. whitei) [121, 209], Nosema cristatellae (=Pseudonosema cristatellae) [125], Nosema kingi (=Tubulinosema kingi), and Nosema acridophagus (=T. acridophagus) [156] have been given new generic designations and other new genera (Trichonosema, Bryonosema, Fibrillanosema) [125, 218], and even two new families, Pseudonosematidae and Tubulinosematidae, have been created [125, 156].

In a recent analysis of 125 microsporidian species (sequences obtained from GenBank), Vossbrinck and Debrunner-Vossbrinck showed that groups or clades are formed based largely on habitat and host [219]. They stated that structural and ultrastuctural characters are unreliable for distinguishing among higher-level microsporidian taxa and, based on their SSU-rRNA analysis, proposed three classes that reflect the habitat of each group: the Aquasporidia, which are found primarily in freshwater habitats; the Marinosporidia, which are found in hosts of marine origin; and the Terresporidia, which are primarily from terrestrial environments. Larsson completely disagrees with Vossbrinck and Debrunner-Vossbrinck about the usefulness of cytological characters for microsporidian systematics [220]. He argues that none of the distinguished clades of microsporidia of marine, freshwater, and terrestrial origin is strictly confined to the particular habit. Another problem with molecular data (especially from public databases) is that morphological evidence for the identification of species is lacking in most molecular studies and nobody really knows the origin of all these sequences in the databases. There is an urgent need for a microsporidian database that contains only DNA sequences together with morphological data of properly defined species so that in the future, only sequences from confirmed species will be used in phylogentic analyses. However, as the new classes (Aquasporidia, Marinosporidia, Terresporidia) have not been described as is required by the relevant taxonomic code (The International Code of Zoological Nomenclature 1999), they are currently nomina nuda that are not valid and that can be made available at a later time [220].

Microsporidian taxonomy has obviously reached a breaking point where classical morphology-based methods are losing importance and will be supplemented or even replaced by molecular-based methods. Without a doubt, molecular techniques present an excellent means of identifying species and also provide excellent data for proposing evolutionary relatedness through phylogenetic analysis. Because sequence data are characters unique to an organism, species descriptions should whenever possible contain sequence data (rRNA). On the other hand, morphological data (primarily obtained by electron microscopy) also provide information that is often unique to a genus or even species, which could be expected since the morphology is determined by the genome. Nevertheless, all published classification systems demonstrate that morphology alone does not provide enough information for producing accurate phylogenies. Several morphological characters of microsporidia, such as the number of nuclei, the number of spores or sporonts, the length, arrangement and structure of the polar tube, and other details of the life cycle may change very rapidly during adaptation to different hosts or tissues, and some characters (e.g., being diplokaryotic, development in direct contact with the host cell cytoplasm) seem to have evolved several times simultaneously in different lineages of microsporidia. Thus, as morphology is the visual expression of the genome, careful evaluation of both molecular and morphological data should lead to phylogenies that are based on two sets of characters and that correspond and are consistent with each other.

\section{EPIDEMIOLOGY AND TRANSMISSION}

Microsporidia have a worldwide distribution and can be found in almost any group of animals including protozoa and helminthes [221]. Since their discovery, they have been well known as the agents of disease in invertebrate hosts (mainly insects) and as the cause of several diseases and mortality in wild, farmed, and aquarium fish. But most research on microsporidia was initially done by entomologists and insect pathologists.

In 1838 , the first microsporidium recorded from a vertebrate host was reported by Gluge [20]. This parasite, later determined to be Glugea anomala [21], causes subcutaneous cysts resulting in spectacular deformations in sticklebacks. Encephalitozoon cuniculi was the first microsporidian to be recognized as a mammalian parasite. They were first seen as Gram positive microorganisms measuring "never more than $4 \times 1.5 \mu \mathrm{m}$ " in the brain, spinal cord, and kidney of laboratory rabbits that were used in experiments on transmission of poliomyelitis by Wright and Craighead in 1922 in Boston [222]. The parasite was named by Levaditi, Nicolau and Schoen [223, 224], who observed similar organisms also in the brain of rabbits. The same authors also suggested that these organisms were microsporidia [224, 225], which was not generally accepted because the presence of the polar filament was not demonstrated [226]. The reports of Levaditi et al. and Wright and Craighead were also neither cited in Kudo's monograph [73] nor by Jírovec [94], and the true nature of Encephalitozoon remained obscure until in the 1960s, when Nelson [227] and Lainson et al. [228] independently rediscovered $E$. cuniculi in laboratory rodents and substantiated the previously rejected claim of the original authors that this parasite is a microsporidium. A persistent infection of laboratory animals was observed at the Rockefeller Institute Farm in Princeton, New Jersey, and Nelson [227], extruding the polar filaments from spores obtained from peritoneal macrophages of infected mice, showed that the responsible organism was indeed a microsporidium. Aggregations of small organisms in mammalian brains had also 
been noted for 50 years in laboratory animals at the Winches Farm Laboratories (a field station of the London School of Hygiene Tropical Medicine in St Albans, Hertfordshire, UK) when Lainson et al. [228] used transmission electron microscopy to demonstrate the presence of the polar filament in spores obtained from rats. These authors and Weiser [229] transferred the species E. cuniculi to the genus Nosema ( $N$. cuniculi) because they concluded that Encephalitozoon was a junior synonym. Ann Cali later differentiated the genera Nosema and Encephalitozoon on the basis of diplokarya in the former and isolated nuclei in the latter and consequently reinstated the genus Encephalitozoon [166]. The genus Anncaliia Issi, Krylova \& Nicolaeva, 1993 was created to honour this important work [230]. Thelohania apodemi was the second microsporidium found in a warm-blooded host [231]. It was identified in the brain of voles collected by $\mathbf{J}$. M. Doby on an excursion together with J. Weiser in the Bretagne, France in an old oak grove at a castle near Ploermal [47].

The first sufficiently documented human case of microsporidial infection was a case of disseminated Encephalitozoon infection in a 9-year-old Japanese boy, who suffered from recurrent fever, headache, vomiting, and spastic convulsions, reported by Matsubayashi et al. in 1959 [232]. The parasite was isolated by inoculating cerebrospinal fluid and urine into mice, and in this case 30 control mice remained negative (this parasite was later identified as Anncaliia (Nosema) connori by Weiser [233]). It was 25 years later that a similar illness in a 2-year-old Columbian child living in Sweden was found to be of microsporidian origin [234]. Another fully substantiated report was published by Margileth et al. in 1973 [234a], and unidentified microsporidia caused corneal infection in two further cases [235, 236]. Thus, microsporidia became important in human and veterinary medicine. This increase in profile stimulated research on microsporidia in mammals, resulting in better funding for the field and producing a new research discipline [47].
Fewer than 10 well-documented human microsporidia infections had been reported up to 1985 when the new species Enterocytozoon bieneusi was described in a 29-year-old Haitian AIDS patient from France [237, 238]. Similar organisms (probably E. bieneusi) had already been observed in intestinal biopsy specimens from several HIV-infected patients since August 1982, but for the pathologists their identification as protozoal parasites of the phylum Microsporidia did not come easily [239]. William Gourley, a pathologist at the University of Texas at Galveston, probably was the first to detect $E$. bieneusi in a duodenal biopsy from a homosexual patient with chronic diarrhoea. Using electron microscopy, he observed spores of a "yeast or protozoan" that was "not recognized by light microscopy". Seven months later he showed the electron micrographs to participants of the annual Binford-Dammin Society of Infectious Disease Pathology dinner at the International Academy of Pathology, U.S. and Canadian Annual Meeting. In attendance were Ronald Neafie and Daniel Connor from the Armed Forces Institute of Pathology, who were familiar with microsporidian ultrastructure from a case of disseminated microsporidian infection in a child [234a], and they recognized the coiled polar filament in the spores. In May 1984 an abstract written by Dobbins and Weinstein describing an unknown organism in a gastrointestinal biopsy from a patient with AIDS [240] came to Gourley's attention. Comparison of both organisms showed that they were identical microsporidia. At about the same time, a similar case was studied by Robert Owen, a gastroenterologist at San Francisco VA Medical Center, and Ann Cali [241]. In August 1993 and March 1994 two similar cases were also observed by Jan Marc Orenstein, pathologist at George Washington University, Washington, D.C., who showed electron micrographs to participants of the First International Conference on AIDS in Atlanta in spring 1995 without success; the identification of these two organisms as microsporidia did not come until Orenstein saw Dobbins and Weinstein's paper that was published in Gastroenterology in

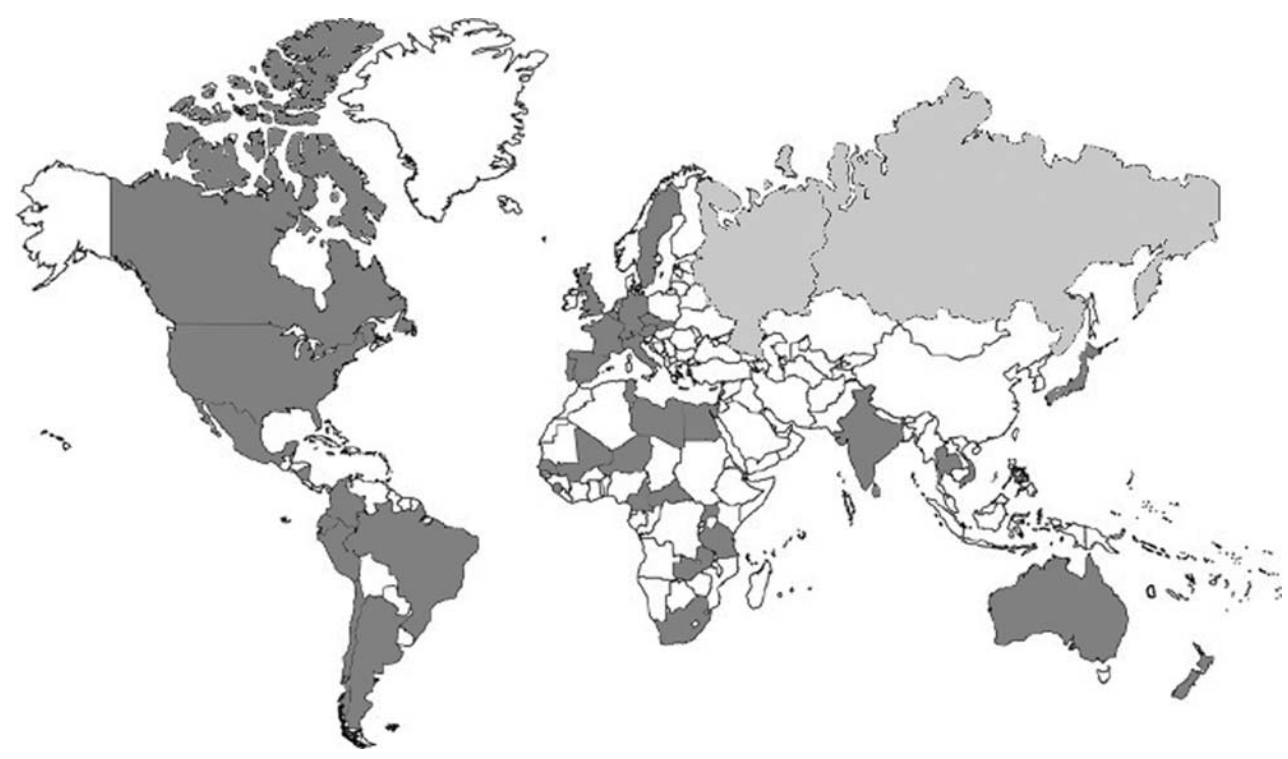

Fig. (27). Geographic distribution of human microsporidiosis. Dark regions indicate areas with published human cases, grey regions indicate areas with cases that have not been published (personal communications). Modified from [245]. Based on a literature review as of September 2005. 
March 1985 [239, 242]. Unaware of this research, R. Modigliani, a French gastroenterologist from Paris, together with Isabelle Desportes observed the same microsporidium in small bowel biopsies of a heterosexual Haitian HIVinfected patient with chronic diarrhoea. They correctly identified the microsporidium as the first member of a new genus that they named Enterocytozoon, and the species was named Enterocytozoon bieneusi after the patient [237, 238].

Only about 40 additional cases occurred in the next five years [243], but as of August 1991, 104 cases of intestinal microsporidiosis attributable to E. bieneusi had been reported [239]. Since then, several hundred patients with intestinal $E$. bieneusi infection have been reported from all continents except Antarctica (Fig. 27); in 1994 the first case in a non HIV-infected patient was reported [244], followed by several other cases in immunocompetent and immunocompromised persons. The occurrence of microsporidiosis as common opportunistic diseases in immunocompromised patients further stimulated research in this field during the last decade of the 20th century.

Two pathogenic species of Encephalitozoon that infect humans, Encephalitozoon cuniculi and Encephalitozoon hellem, are morphologically similar by light and electron microscopy, and can only be distinguished by antigenic, biochemical, or nucleic acid analysis. Several cases of Encephalitozoon infection were reported to occur in patients with and without AIDS prior to 1991 [246, 247]. It was assumed that these infections were due to $E$. cuniculi following light and/or electron microscopic analysis. However, in 1991 Didier et al. used biochemical and antigenic methods to describe a new species of Encephalitozoon, termed Encephalitozoon hellem, found in three patients with AIDS [248]. This new species was morphologically indistinguishable from $E$. cuniculi and required special methods to differentiate from it. Following that report, all published cases of Encephalitozoon infections in humans appeared to be caused by $E$. hellem [249]. There was some doubt as to whether E. $c u$ - niculi did in fact cause human infection until 1995, when De Groote et al. and Franzen et al. described two homosexual men with AIDS and disseminated E. cuniculi infection, confirmed by an immunofluorescent assay and by DNA identification $[250,251]$. To date, E. cuniculi has been detected in at least 20 and $E$. hellem in about $50 \mathrm{HIV}$-infected or otherwise immuno-compromised patients [252].

A third species of Encephalitozoon, Encephalitozoon intestinalis, was first described in 1992 by Orenstein et al. as a microsporidium with ultrastructural similarities to the genus Encephalitozoon [253]. Nevertheless, it has been placed as a new species in a new genus, Septata intestinalis by Cali et al. [254], but on the basis of DNA sequence data it later was placed in the genus Encephalitozoon and renamed Encephalitozoon intestinalis [255]. E. intestinalis is one of the most common microsporidial species in humans (beside $E$. bieneusi) and has been reported in at least 200 patients [252].

Several other new species (Trachipleistophora hominis [256], Trachipleistophora anthropophthera [135], Nosema ocularum [257], Pleistophora ronneafiei [258], Vittaforma corneae [217, 259], Anncaliia (formerly Brachiola/Nosema) vesicularum [260], Anncaliia (formerly Brachiola/Nosema) connori [261], Microsporidium africanum [236], Microsporidium ceylonensis [235]) or species new in humans (Anncaliia (formerly Brachiola/Nosema) algerae [262, 263]) have been detected during the last decades, but infections with these parasites are reported only as sporadic cases (q.v. Diseases).

Data on epidemiological characteristics of microsporidiosis are rapidly increasing, but many questions have yet to be answered. Reliable estimates of prevalence are missing because nearly all published studies are not based on truly random samples but refer to highly selected patient populations, such as HIV-infected patients with chronic diarrhoea. Different diagnostic approaches, noncontrolled and nonrandom study designs, and multiple species with diverse clinical

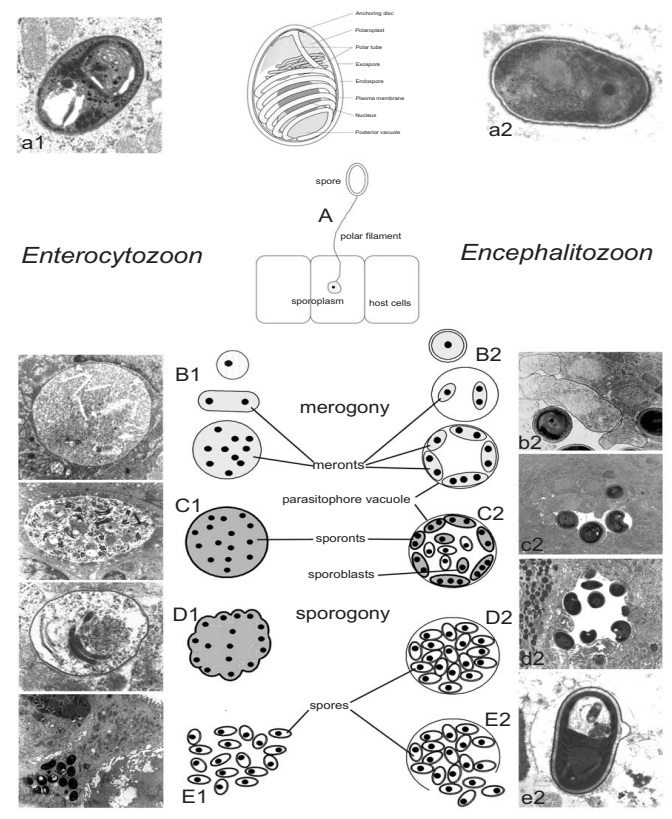

Fig. (28). Major and minor pathways of transmission for insect parasitic microsporidia (from [264] with permission). 
manifestations make it very difficult to understand the true burden of microsporidiosis. Studies on Enterocytozoon bieneusi in AIDS patients with chronic diarrhoea have reported prevalences between $4 \%$ and $50 \%$, depending on the study group and method of diagnosis. Combined, these studies have evaluated over 2,500 patients and confirmed about 500 cases of E. bieneusi infection (20\%) and the total number of reported cases exceeds 1,000. Epidemiological estimates of Encephalitozoon infections have not been done so far [252].

Transmission of microsporidia in insects has been studied for a long time and both vertical (transovarial) as well as horizontal transmission occur regularly among insects (for review see Fig. 28 and [264, 265]).

Routes and sources of human infection have been difficult to ascertain, but animal reservoirs of microsporidia infecting humans have been confirmed recently (Table 1) [252, 266]. For E. cuniculi several animal hosts were already known long before it was described as a pathogen in humans, and this species is commonly found in several mammals [267, 268]. Before the description of E. hellem in 1991, Encephalitozoon-like microsporidia were described on several occasions from psittacine birds (parrots) [118]. Later, molecular analyses confirmed that cases of E. hellem in psittacine birds derived from budgerigar chicks (Melopsittacus undulatus), two eclectus parrots (Eclectus roratus), and peach-faced lovebirds (Agapornis roseicollis). The first detection of E. hellem in a wild psittacine bird was a yellowstreaked lory (Chalopsitta scintillata) captured on Aru Island (Indonesia), and infections have been reported from nonpsittacine birds as well [horned puffin (Fratercula corniculata), ostrich (Struthio camelus), several species of hummingbirds, and Gouldian finch (reviewed by [252, 266, 269]). E. intestinalis was detected by an immuno-fluorescence test using a monoclonal antibody in fecal samples from several domestic animals from a rural area in central Mexico [270]. Transmission electron microscopy on these specimens revealed microsporidian-like structures. PCR was done several months later, and fecal samples from goat, pig, cow, dog, and donkey were positive for E. intestinalis but negative for $E$. $c u$ niculi and E. hellem [271]. Other studies have not confirmed these high-prevalence data, and the situation regarding $E$. intestinalis is still unclear. Eleven years after its discovery as a human pathogen, E. bieneusi was for the first time detected in animals (pigs) [272], and subsequent studies have confirmed the occurrence of E. bieneusi in pigs and calves with high prevalence [273]. The parasite has also been detected in cats, dogs, a goat, a llama, a variety of species of wild mammals (beavers, foxes, muskrats, otters, and raccoons), hedgehogs, and, recently, nonmammalian hosts (chickens and pigeons). Natural infections with $E$. bieneusi have been documented in captive monkeys, namely, rhesus macaques (reviewed in [252]).

In 1993, Lom suggested that microsporidian isolates of the same species from different hosts may differ and that this may have bearing on the varying degree of susceptibility in different hosts and thus on epidemiology [274]. Molecular analysis of different human E. cuniculi isolates and isolates from rabbits, dogs, mice, and blue foxes later showed that there are indeed differences [275] and that all isolates from humans were of the same subtype as the isolates from rabbits (strain I) and dogs (strain III) (Table 1) [276]. Strain II, that is found in mice and rats, has never been identifierd in humans. However, no direct proof of transmission from animals to humans has been documented, with the exception of one case in which a 10-year-old girl seroconverted after close contact with a dog infected with E. cuniculi [277]. Thus, firm evidence for transmission of microsporidia from animals to humans is currently lacking, but clues are emerging as to possible animal links with human microsporidial disease. As with E. cuniculi, different genotypes have been identified for $E$. hellem, and one genotype was determined for isolates from several patients from the U.S. and Europe and for one isolate each from a parrot caught in the wild in Indonesia and from a psittacine bird from the U.S. Other genotypes consist of human-derived $E$. hellem isolates from Switzerland (three isolates) and Tanzania (one isolate). In contrast to the situation with other human-infecting Encephalitozoon spp., E. intestinalis seems to be a very homogeneous species, and no genetic differences have been detected among different isolates so far. Seventeen different ITS genotypes of $E$. bieneusi infecting humans have been confirmed, but limited information is available on the geographic distribution of human-derived genotypes, and only four seem to have a zoonotic potential, having also been discovered in vertebrate hosts with what appears to be some degree of host specifity. Further characterization of both animal and human microsporidia will certainly produce firm evidence for the zoonotic origin of human microsporidiosis and as several studies have found microsporidia in animals that are associated with or farmed by humans, then such infections may be zoonotic.

Arthropods are the most common hosts of microsporidia, and experimental infections of mice by Anncaliia (formerly Brachiola/Nosema) algerae - a mosquito parasite that molecular biology indicates is phylogenetically distant from typical members of the genus Nosema - have been achieved $[278,279]$. Human cases of keratitis and myositis caused by A. algerae have been reported [262,263], and the ultrastructural features of Anncaliia vesicularum, which have been identified in muscle biopsies of an HIV-infected patient, are most closely aligned with A. algerae as well [260]. But whether other insect microsporidia might infect vertebrates or even humans is unknown and currently under investigation [156].

Common environmental sources of microsporidia include ditch and other surface waters, and several species of microsporidia can be isolated from such sources [280]. Detection of human microsporidia (E. bieneusi, E. intestinalis, and $V$. corneae) in environmental water samples has been reported $[281,282]$, and there is one report of a presumed waterborne outbreak [283]. Risk factors for intestinal microsporidiosis also suggest water as the source of infection [284], but whether microsporidiosis is a really a waterborne disease is unknown [285].

There is considerable serologic evidence that humans without clinical signs of infection have been exposed to microsporidia (studies have focused exclusively on human exposure to Encephalitozoon spp.) [286-289], but whether these persons are chronically infected or active infections are newly acquired is unknown; neither are the sources of 
Table 1.

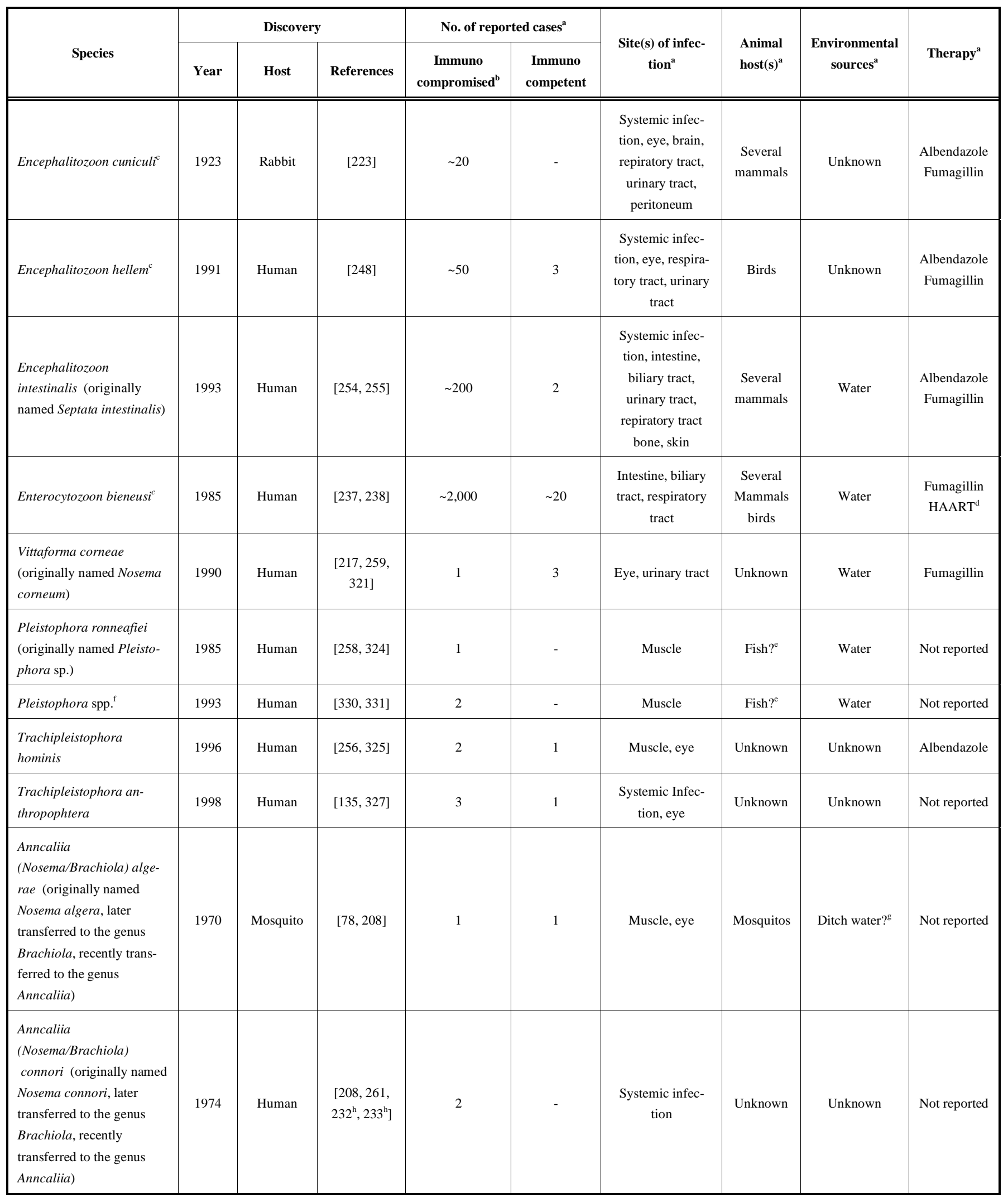


(Table 1). Contd.....

\begin{tabular}{|c|c|c|c|c|c|c|c|c|c|}
\hline $\begin{array}{l}\text { Anncaliia (Brachiola) } \\
\text { vesicularum (originally } \\
\text { named Brachiola } \\
\text { vesicularum recently } \\
\text { transferred to the genus } \\
\text { Anncaliia) }\end{array}$ & 1998 & Human & {$[208,260]$} & 1 & - & Muscle & Unknown & Unknown & Not reported \\
\hline Nosema ocularum & 1991 & Human & [257] & - & 1 & Eye & Unknown & Unknown & Fumagillin \\
\hline $\begin{array}{l}\text { Microsporidium } \\
\text { ceylonensis }\end{array}$ & 1973 & Human & {$[118,235]$} & 1 & - & Eye & Unknown & Unknown & Not reported \\
\hline Microsporidium africanum & 1981 & Human & {$[118,236]$} & 1 & - & Eye & Unknown & Unknown & Not reported \\
\hline
\end{tabular}

a adepted from several references.

${ }^{\mathrm{b}} \mathrm{HIV}$-infected patients or otherwise immunocompromised patients including organ transplant recipients.

c different genotypes have been reported.

${ }^{\mathrm{d}}$ highly active antiretroviral therapy leading to immunreconstitution in HIV-infected patients.

${ }^{\mathrm{e}}$ species of the genus Pleistophora are known to infect fish, but wether $P$. ronneafiei infect fish is unknown.

${ }^{\mathrm{f}}$ re-examination suggested that both cases involved an infection due to Trachipleistophora [328].

${ }^{\mathrm{g}}$ Nosema sp. that was morphological identical at the light microscopic level to A. algerae [280].

${ }^{\mathrm{h}}$ suspected to be Anncaliia (Nosema/Brachiola) connori by Weiser [233].

human infections really known. Spread within the human population and acquisition of parasites from animals or water are obvious possibilities that can be neither confirmed nor denied at this time. If persistence of antibodies is indicative of latent infections, reactivation is likely to occur under immunosuppression.

\section{DIAGNOSIS}

Serological methods such as ELISA and western blot assays have been useful for diagnosing microsporidiosis in immunologically competent laboratory animals and humans [286-289]. However, reliance on these E. cuniculi-based serology assays became complicated by the emergence of new species of microsporidia found to infect humans and animals and by concerns that microsporidia infections often occur in immunodeficient individuals who may not express significant or specific antibody responses [276].

Microsporidia are difficult to detect, and usually special techniques are necessary to diagnose microsporidia infections [290]. Identification of microsporidia has been based primarily on ultrastructural studies using transmission electron microscopy. Microsporidial ultrastructure is unique and pathognomonic for the phylum, and electron microscopy allows one to distinguish among all microsporidial genera [140]. However, during the last decade, diagnostic procedures to detect microsporidia have been changed remarkably and have been reviewed several times (e.g. [290-292]). New staining methods, suitable for light microscopy, have been developed, and modified trichrome stains (concentrated chromotrope 2R) [293] and fluorescent staining techniques using optical brighteners (e.g. Uvitex 2B, Calcofluor White, or Fungifluor) [294, 295] were major breakthroughs. Originally used for stool and body fluids, these stains were later adopted for the staining of histological sections as well [296, 297]. Microsporidia stain poorly with $H$ \& E in tissue sections, but tissue Gram stains (Brown-Brenn and BrownHopps) are useful for detecting microsporidia in tissue biopsies, and silver stains (e.g. Warthin-Starry) also have been applied for detecting microsporidia in tissue sections [292]. Another excellent method for revealing microsporidia is
Goodpasture's carbol-fuchsin stain. Immunofluorescent staining techniques using poly- and/or monoclonal antibodies are established in several research labs, but none of these antibody detection procedures has been commercialized so far. Nucleotide sequencing of microsporidian genes offers new opportunities to perform highly sensitive molecularbased techniques, such as polymerase chain reaction, with many advantages in diagnosis and species differentiation of human micro-sporidial infections [290, 298, 299].

Establishment of an in vitro propagation system for microsporidia enables pathobiological studies of the parasites and the production of large numbers of spores for many different types of in vitro and in vivo studies, including the generation of monoclonal and polyclonal antibodies, and immunologic, molecular, biochemical, physiologic, and animal inoculation studies [300]. Initially, microsporidia were mostly cultivated in insect cell lines. Trager in 1937 achieved partial success in culturing $N$. bombycis [301], but Ishihara and Sohi in 1966 were the first to publish a truly successful and practical method of growing $N$. bombycis in ovarian tissue culture of Bombyx mori [302]. Ron Ishihara began to study microsporidia in Tokyo, Japan, in the $1960 \mathrm{~s}$ and later contributed significant findings to the microsporidia literature. He moved to Ontario, Canada, where he established the in vitro culture of $N$. bombycis [301] and elucidated the prokaryotic nature of microsporidian ribosomes [189]. Back in Japan, he discovered the previously unknown binucleate spores of some Nosema spp. that function in the spread of infection to other tissues [183, 184].

Undeen in 1975 established the first microsporidian species in a mammalian cell line by growing Anncaliia algerae in pig kidney cells at $26^{\circ} \mathrm{C}$ [302a]. This parasite, which also causes human infections [262, 263], has later been successfully grown in many insect cell cultures [303, 304] and other mammalian cells as well [263, 305, 306].

Interest in the in vitro cultivation of certain microsporidia that cause human disease intensified in recent years after several genera were identified as opportunistic pathogens of humans, especially in AIDS patients, and this approach was pioneered by Govinda S. Visvesvara. Murine isolates of $E$. 
cuniculi had already been cultivated in cell cultures by Shadduck in 1969 [307] and later by other researchers [308], when in 1991, Visvesvara et al. and independently Didier et $a l$. isolated $E$. hellem from HIV-infected patients [248, 311]. Hence, a number of isolates of E. cuniculi, E. hellem, and E. intestinalis, two isolates each of Vittaforma corneae, Anncaliia (formerly Brachiola/Nosema) algerae, and Trachipleistophora hominis and one isolate of Trachipleistophora anthropophthera have been established in culture, many of them in Visvesvara's lab in Atlanta, Georgia [300]. However, the most common microsporidial species infecting humans, E. bieneusi, has not yet been cultured in long-term cultures [310], which has inhibited progress in finding an effective antimicrosporidial agent against this important infection.

\section{DISEASES}

Microsporidia are widespread pathogens of invertebrates and fish, and almost half of the described microsporidian genera have an insect as type host. There is a wide variation in the types of pathologies that can occur in insects as a result of infection with microsporidia. Infections are usually chronic, slow-acting processes and are rarely acute. The various signs and symptoms associated with microsporidiosis in insects range from obvious tissue manifestations to abnormal developmental and behavioural changes [264]. Economically important diseases caused by insect microsporidia have been mentioned above: Pébrine disease in silkworms is caused by $N$. bombycis, and severe dysentery in honeybees is caused by $N$. apis. $N$. bombi infects bumblebees that are used to pollinate plants in greenhouses, and several other diseases in economically important insects occur (for review see [264, 311].

About 150 microsporidia species from 14 genera have been described from fish, and several cause severe diseases [312]. Fish microsporidia can be divided into those associated with xenoma formation (e.g. Glugea, Ichthyosporidium, Jirovecia, Loma, Microfilum, Microgemma, Nosemoides, Spraguea, and Tetramicra) and non-xenomaforming species (Nucleospora, Heterosporis, Pleistophora, and Thelohania) [313]. Some are host specific, at least at the genus level, but a few are widely distributed among different hosts. Comprehensive lists of fish hosts and their microsporidia can be found in Canning and Lom (1986) and Lom (2002) [118, 312]. Microsporidiosis in fish are of important economic impact because diseases not only occur in wild and cultured food fish but also in aquarium fish [118]. In wild fish, declines of entire commercial fisheries have been attributed to microsporidiosis: In 1946 Pleistophora macrozoarcides was responsible for the collapse of the North American ocean pout fishery [314], and the decline in the rainbow smelt fishery of New Hampshire was caused by infections from Glugea hertwigi [315]. Cultured fish are particularly susceptible to microsporidia, and high mortality has occurred in farmed fish from infections of Heterosporis anguillarum, Loma salmonae, or Nucleospora salmonis and in ornamental fish by Glugea spp. Pleistophora hyphessobryconis is well known to fish hobbyists as the cause of the extremely common neon tetra disease [118] (for review see [313]).
Microsporidial infections have been reported in various wild and domestic mammalian animals and also from avian, amphibian, and reptilian hosts [267, 269], and the history of mammalian microsporidiosis has already been described above. Species occurring in vertebrate hosts were summarized for the first time by Canning and Lom in 1986 [118]. As already mentioned earlier, E. cuniculi occurs regularly in rabbits, causing encephalitis and chronic renal disease and in several wild and laboratory rodents. E. hellem has been reported in different birds with and without symptoms (enteritis). Several other species have been described in vertebrates, but most of these only as single reports (for review see [267]).

Microsporidia in humans are considered opportunistic pathogens because they are most likely to cause disease if the immune status of a host is suppressed so that the infection cannot be controlled. Clinical symptoms and diseases associated with microsporidiosis vary with the species causing the infection and the status of the host's immune system. During the last decade of the 20th century, the clinical pictures of human microsporidiosis have been described in hundreds of case reports and research papers and have been reviewed several times (e.g. [276, 295, 316, 317]).

The most common clinical manifestation of human microsporidiosis is diarrhoea resulting from infection with $E$. bieneusi or the less-common E. intestinalis. HIV-infected patients with fewer than $100 \mathrm{CD} 4$ cells per microliter are most susceptible, but otherwise immunocompromised or even healthy individuals, such as travellers, may be affected as well [318-320]. Whereas E. bieneusi causes relatively localized disease mainly of the gastrointestinal tract and less commonly of the respiratory tract, all three Encephalitozoon spp. typically disseminate causing clinical syndromes that include sinusitis, keratoconjunctivitis, encephalitis, tracheobronchitis, interstitial nephritis, hepatitis, or myositis, and microsporidiosis should be considered in the differential diagnosis of HIV-related symptomatic disease of virtually all organ systems (Table 1). However, there are clear differences in the typical distribution pattern for each microsporidian species. E. hellem mainly parasitizes the keratoconjunctivals, urinary tract, nasal sinuses, and bronchial system. On the other hand, E. intestinalis appears to be mainly confined to the gastrointestinal and biliary tracts with dissemination to the kidneys, eyes, nasal sinuses, and sometimes the respiratory tract. E. cuniculi causes widely disseminated infections involving nearly all organ systems, but clinical manifestations vary substantially, ranging from no symptoms to severe disease with the gastrointestinal tract only sporadically involved.

Additional species have caused diseases in humans with less frequency. Corneal infection was caused by $M i$ crosporidium africanum in a young woman [236] and by Microsporidium ceylonensis in a young boy [235]. Nosema ocularum caused a corneal ulcer in a 39-year-old man [257], and Vittaforma corneae caused stromal keratitis in three immune-competent individuals [217, 259, 321, 322], and urinary tract infection in a patient with AIDS [323]. Anncaliia (Brachiola/Nosema) algerae, a microsporidium commonly found in mosquitoes, has been found as the cause of keratitis and fatal myositis in humans [262, 263]; Anncaliia (formerly 
Brachiola) vesicularum caused myositis in a patient with AIDS [260]; and a disseminated infection due to Anncaliia (formerly Brachiola/Nosema) connori was responsible for diarrhoea and malabsorption in an athymic infant [234]. Pleistophora ronneafiei caused myositis in an immunecompetent man [258, 326]. Trachipleistophora hominis was isolated from two AIDS patients with myositis and an immunocompetent man with stromal keratitis [256, 322, 325, 326], and Trachipleistophora anthropophthera was detected in several organs at autopsy of two patient with AIDS and in the cornea of a third HIV-infected patient [135, 327-329]. Re-examination of two other cases of myositis, where the responsible organisms were reported as Pleistophora spp. $[330,331]$, suggested that both cases involved an infection of Trachipleistophora, as well [326].

The "new" microsporidian species, E. bieneusi, E. hellem, E. intestinalis, T. hominis, T. anthropophthera, and A. vesicularum were first identified in HIV-infected patients, but recent cases have indicated that most of these microsporidian species are not confined to HIV-infected patients. E. bieneusi and E. intestinalis have been detected as a cause of self-limiting diarrhoea in immunocompetent persons [244, 320], and microsporidia have emerged recently as cause of disease in patients who were immunosuppressed secondary to organ transplantation [332-334]. Intestinal microsporidiosis seems to be an underappreciated cause of travelers' diarrhoea, as well [318-320].

\section{THERAPY}

Many different chemicals have been tested for control of nosematosis in honeybees, but only Fumagillin (Fumidil$\mathrm{B} \circledast$, Nosem- $\mathrm{X}^{\mathrm{TM}}$ ), an acyclic antibiotic produced by some strains of Aspergillus fumigatus and originally isolated because of its antibiotic properties, especially against protozoa such as Entamoeba histolytica and Plasmodium spp., has proven effective [335]. Since fumagillin does not affect spores, treatment with this drug does not completely eliminate the disease from the bee colony, and the infection will continue after all the medication has been stopped. Fumagillin is also very effective against human microsporidia, and efficacy against $E$. cuniculi was already demonstrated by Shadduck in 1980, who suggested that the drug may be useful for the treatment of encephalitozoonosis [336]. Although Fumagillin was really used for the first time to treat microsporidial keratoconjunctivits in three HIV-infected patients as topical treatment by Diesenhouse et al. and by Rosberger et al. in 1993 [337, 338], several other successfully treated patients have been reported since (for review see [339]). Used systemically, Fumagillin is also an effective treatment for chronic E. bieneusi infection in immunocompromised patients, but severe side effects (neutropenia and thrombocytopenia) were observed in $50 \%$ of patients under therapy [340]. The synthetic fumagillin analog TNP-470 was as effective as fumagillin against microsporidia in in vitro studies [341] and was well tolerated systemically in AIDS patients with Kaposi's sarcoma, but other human studies with microsporidiosis are lacking [342].

Initial reports about successful treatment of intestinal microsporidiosis with metronidazole were not supported by later studies, and metronidazole has no effect on mi- crosporidia in in vitro cultures [343]. Several other agents were tested without success until albendazole, a benzonidazole that binds to tubulin, was found to be highly effective against at least some insect and human microsporidian species [343, 344]. Human infections with Encephalitozoon spp. that were treated with albendazole showed remarkable improvement of symptoms and clearance of the parasite after therapy [345]. Initial reports described some clinical efficacy of albendazole against E. bieneusi as well [346, 347], but subsequent studies failed to show any effect [348].

Since the introduction of highly active antiretroviral therapy in HIV-infected patients, the prevalence rates for microsporidiosis in these patients have fallen dramatically, and several reports have shown remission of microsporidiaassociated symptoms under therapy [349-352] and even clearance of the parasites has been described [353].

\section{CONCLUSION}

Since the naming of Nosema bombycis 150 years ago, there has been a lot of research on the microsporidia, and because microsporidia infect a wide range of host species, diverse disciplines were engaged in this research with limited opportunities for interaction. Historically, researchers dealing with microsporidia from various hosts have discussed these organisms within their segregated scientific communities [203]. Insect microsporidiologists interacted separately from people dealing with microsporidia infecting fish and from parasitologists, pathologists, and infectious disease specialists dealing with mammalian and human microsporidia. While the insect microsporidiologists had their annual meeting of the Society for Invertebrate Pathology, and people dealing with fish microsporidia attended the $I n$ ternational Symposia on Fish Parasites, other researchers met in symposia as part of international protozoology meetings [e.g., the International Congresses of Protozoology (ICOP)] or at specialised meetings dealing with microsporidia as opportunistic pathogens [e.g. the International Workshops on Opportunistic Protists (IWOP 1-8), the Workshop on Intestinal Microsporidia in HIV infection organized in Paris, France in 1992, or the Workshops on Microsporidiosis and Cryptosporidiosis in Immunodeficient Patients in České Budějovice, Czech Republic in 1993 and 1997 (Fig. 29)].

However, in 2004 a NATO advanced research workshop (ARW) was held from July 12 to 15,2004 , at the Institute of Parasitology of the Academy of Sciences of the Czech Republic in Ceské Budějovice, Czech Republic. This meeting entitled Emergent Pathogens in the 21st Century: First United Workshop on Microsporidia from Invertebrate and Vertebrate Hosts, brought together experts in insect, fish, veterinary, and human microsporidiosis to discuss the state of knowledge of microsporidia (Fig. 30). Important contributions of this meeting were presented as articles in a special issue of Folia Parasitologica, edited by Jiří Lom, Jiř́ Vávra, Louis M. Weiss, and Vladimír Bukva (Vol. 52, Number1/2, May 2005), which also contained all 55 abstracts of this important meeting.

In 2007 a Second United Workshop on Microsporidia from Invertebrate and Vertebrate Hosts was held during the $V$ European Congress of Protistology from July 23 to 27, 


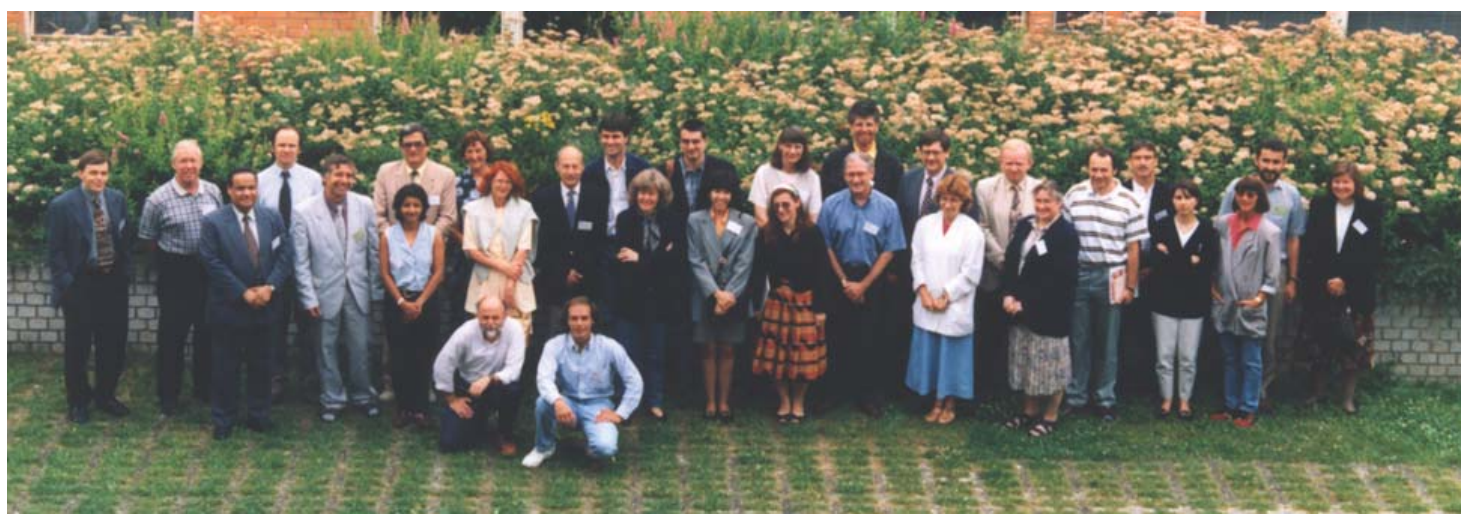

Fig. (29). Participants at the Second Workshop on Microsporidiosis and Cryptosporidiosis in Immunodeficient Patients, June 30 to July 3 , 1997, in České Budějovice, Czech Republic.

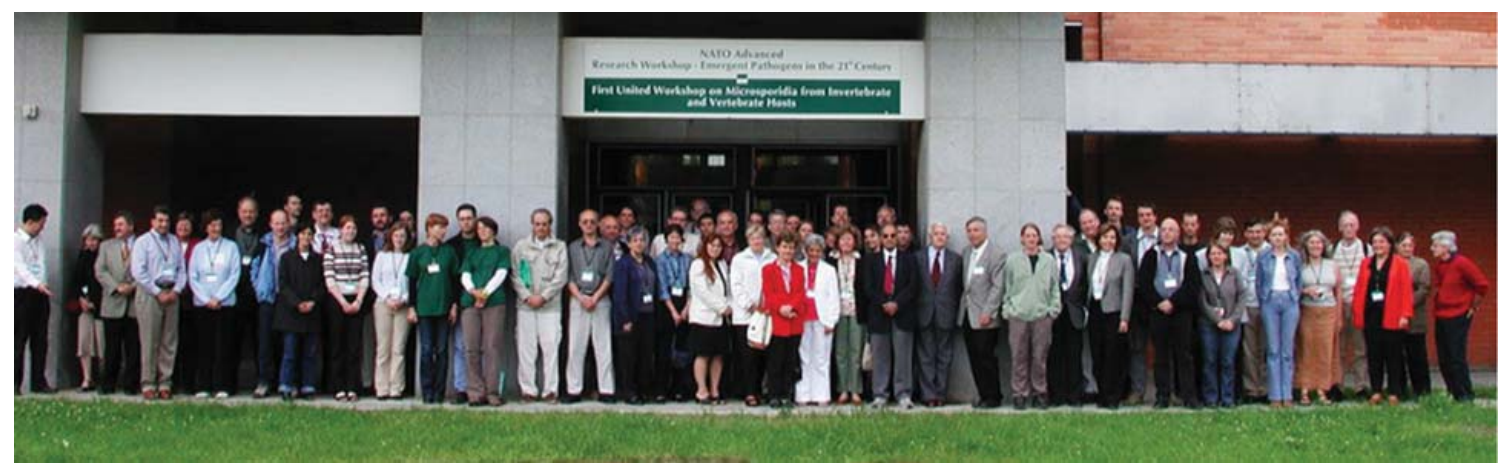

Fig. (30). Participants of the First United Workshop on Microsporidia from Invertebrate and Vertebrate Hosts held in České Budějovice, Czech Republic, in July 2004.

2007 in St. Petersburg in Russia and the attendees agreed to meet every three or four years for such a meeting.

\section{ACKNOWLEDGEMENTS}

This work was supported by a grant from the Bundesministerium für Bildung und Forschung, (BMBF)-Programm zur Förderung von Klinischen Forschergruppen in der Klinischen Infektiologie, Förderkennzeichen 01 KI 9952. I thank Jürgen Schölmerich, Regensburg, Germany, for help and advice and Paul Kretchmer, San Francisco, California for editorial assistance during preparation of this manuscript. I am indebted to Jiří Vávra and Jaroslav Weiser, Prague, Czech Republic, Liz Canning, London, UK, Murray Wittner and Louis Weiss, New York, New York, and Jimmy Becnel, Gainesville, Florida, for their help in gathering all the required information and figures, for their critical reviews, and for many insightful suggestions.

\section{REFERENCES}

[1] Nägeli C. Über die neue Krankheit der Seidenraupe und verwandte Organismen. Bot Zeitung 1857; 15:760-761.

[2] Nöggerath, Kilian. Protocoll der zweiten allgemeinen Sitzung am 21. September 1857. Tageblatt der 33. Versammlung Deutscher Naturforscher und Ärzte in Bonn im Jahre 1857. 1857; 4: 25-32.

[3] Lebert. Über die gegenwärtig herrschende Krankheit des Insektes der Seide. pp. 16-74. In: Jahresbericht über die Wirksamkeit des Vereins zur Beförderung des Seidenbaues für die Provinz Brandenburg. 1856-1857 (reprinted in Berliner Entomologische Zeitschrift 1858; 2: 149-86).
[4] Paulsen F. Die Entdeckung der Krankheitserreger. Ciba Zeitschriften Nr. 14, Ciba, Basel, Swizerland 1934.

[5] Quatrefages A. Etudes sur les maladies actuelles du vers à soie. Mém Acad Sci Inst Imper France 1860; 30: 1-640.

[6] Quatrefages A. Rapports du Jury international de l'Exposition universelle de 1867. 1868.

[7] Pasteur L. Études sur la maladie des vers à soie. Gauthier-Villars, Paris, France 1870. (reprinted in 1926 by Masson, Paris).

[8] Wittner M. Historic perspective on the microsporidia: expanding horizons. In: Wittner M, Weiss LM, Eds. The Microsporidia and Microsporidiosis, Washington, USA: ASM Press 1999; pp. 1-6.

[9] Cornalia E. Monografia del bombice del gelso (Bombyx mori Linn.). Milan, Italy 1856.

[10] Cornalia E. Rapporto della Commissione etc. per lo studio della malattia dei bachi da Seta nell' anno 1856. Milan, Italy 1857.

[11] Cornalia E. Sui caratteri che presenta il seme sano dei bachi da seta e come questo si possa distinguere dal seme infetto. In: Atti della Società Italiana di Scienze Naturali e del Museo Civico di Storia Naturale in Milano, Vol 2. Milan, Italy 1859-1860; pp. 255-70.

[12] Leydig F. Zur Anatomie von Coccus hesperidum. Z Wiss Zool 1854; 5: 1-12.

[13] Leydig F. Der Parasit der neuen Krankheit der Seidenraupe noch einmal. Archiv fuer Anatomie und Physiologie und wissenschaftliche Medicin 1863; 186-192.

[14] Balbiani G. Sur les microsporidies ou sporogspermies des articules. C R Acad Sci Paris 1882; 95: 1168-71.

[15] Stempell W. Über Nosema bombycis Nägeli. Arch Protistenkd 1909; 16: 281-358.

[16] Bütschli O. Protozoa. In: Bronn HG, Ed. Klassen und Ordnungen des Thier-Reichs. I. Abt. Sarkodina und Sporozoa., Leipzig/Heidelberg, Germany: Winter'sche Verlagshandlung 18801882.

[17] International Comission on Zoological Nomenclature International Code of Zoological Nomenclature, 4 th ed. London, UK: The Inter- 
national Trust for Zoological Nomenclature c/o The Natural History Museum. 1999.

[18] Vittadini C. Sul modo di distinguere nei bachi da seta la semente infetta della sana. Atti Int Lomb 1859; 1: 360-3.

[19] Thomson P. The silkworm mystery. The story of Louis Pasteur. Hove, United Kingdom: Macdonald Young Books 1898.

[20] Gluge G. Notice sur quelques points d'anatomie pathologique comparée, suivie de quelques observations sur la structure des branchies dans épinoches. Bull Avad R Belg 1838; 5: 771-85.

[21] Moniez R. Observations pour la revision des Microsporidies C R Acad Sci Paris 1887; 104: 1312-5.

[22] Creplin JGH. Beschreibung der Psorospermien des Kaulbarsches nebst einigen Bemerkungen über die der Plötze u. a. Archiv für Naturgeschichte, Berlin 1842; 8: 61-6.

[23] Müller J. Über eine eigentümliche krankhafte parasitische Bildung mit spezifisch organisierten Samenkörperchen. Bericht der Preußischen Akademie der Wissenschaft 1841; 246-250.

[24] Pfeiffer L. Beiträge zur Kenntnis der pathogenen Gregarinen. I Die Mikrosporidien und die Fleckenkrankheit (Pebrine) des Seidenspinners. Zeit Hyg 1888; 3: 469-86.

[25] Leuckart R. Allgemeine Naturgeschichte der Parasiten mit besonderer Berücksichtigung der bei dem Menschen schmarotzenden Arten. Leipzig/Heidelberg, Germany: Winter'sche Verlagshandlung 1879.

[26] Sprague V. Classification and phylogenie of the Microsporidia. In: Bulla LE, Cheng TC, Eds. Comparative Pathobiology. Vol. 2. New York, USA: Plenum Press 1977; pp. 1-30.

[27] Sprague V, Becnel JJ, Hazard EL. Taxonomy of phylum Microspora. Crit Rev Microbiol 1992; 18: 285-395.

[28] Sprague V, Becnel JJ. Note on the name-author-date combination for the taxon microsporidies Balbiani, 1882, when ranked as a phylum. J Invertebr Pathol 1998; 71: 91-4.

[29] Labbé A. Microsporidiida. In: Bütschli O, Ed. Das Tierreich Vol. 5. Sporozoa., Berlin, Germany: Friedländer und Sohn 1899; pp. 104112.

[30] Zander E. Handbuch der Bienenkunde. II Krankheiten und Schädlinge der erwachsenen Bienen. Stuttgart, Germany: Ulmer 1911.

[31] Dönhoff, Leuckart R. Ueber Fadenpilze im Darm der Biene. Bien Zeit 1857; 13: 66-7.

[32] Dönhoff. Ueber die Ansteckungsfähigkeit der Pilzsucht. Bien Zeit 1857a; 13: 199.

[33] Dönhoff. Ueber Verbreitung der Pilzsucht. Bien Zeit 1987b; 13: 210.

[34] Fantham HB, Porter A. The morphology, biology, and economic importance of Nosema bombi n. sp., parasitic in various humble bees (Bombus spp.). Ann Trop Med Para 1914; 8: 622-38.

[35] Fantham HB, Porter A. The morphology and life history of Nosema apis and the significance of its various stages in the so-called 'Isle of Wight' disease in bees (Microsporidiosis). Ann Trop Med Para 1912; 6: 163-95.

[36] Rennie J. Isle of Wight disease in hive bees - Acarine disease: The organism associated with the disease Tarsonemus woodi, n. sp. Trans R Soc Edinb Earth Sci 1921; 52: 768-79.

[37] Gurley RR. On the classification of Myxosporidia, a group of protozoan parasites infesting fishes. Bull U S Fish Comm 1893; 11: 407-20.

[38] Thélohan P. Sporozoaires nouveaux, parasites des muscles des poissons. C R Acad Biol 1891; 3: 27-9.

[39] Gurley RR. The Myxosporidia, or Psorosperms of fishes and the epidemics produced by them. Rep U S Fish Comm 1894; 18: 65304.

[40] Léger L. Etude sur le rendement cultural des eaux alpines. Monographie du Bassin d'essai no 5 et experiences de rendement. Ann Univ Grenoble $1909 ; 21: 210$.

[41] Léger L, Duboscy O. Sur une microsporidie parasite d'une grégarine C R Acad Sci Paris 1909; 138: 733-4.

[42] Léger L, Hesse E. Sur la structure de la spore des microsporidies. C R Soc Biol Paris 1016; 79: 1049-53.

[43] Léger L, Hesse E. Microsporidies nouvelles parasites des animaux d'eau douce. II. Microsporidies bactériformes et essai de systematique du groupe. Trav Lab Hydrobiol Pisc Univ Grenoble 1924; 14.

[44] Hesse E. Etudes sur les Microsporidies. I Sur une nouvelle microsporidie tétrasporeé du genere Gurleya. II Sur la présence de microsporidies du genere Thelohania chez les insectes. Ann Univ Grenoble 1904; 16: 1-4.
[45] Hesse E. Microsporidies nouvelles des insectes. C R Assoc Franc Avanc Sci 1905; 33: 917-9.

[46] Léger L, Hesse E. Microsporidies bacteriformes et essai de systématique du groupe. C R Acad Sci Paris 1922; 174: 327-30.

[47] Weiser J. Microsporidia and the society for invertebrate pathology: A personal point of view. J Invertebr Pathol 2005; 89: 12-8.

[48] Debaisieux P. Etudes sur les Microsporidies. II. Glugea sanilewskyi L. Pfr. III. Glugea mülleri L. Pfr. Cellule 1919; 30: 153-83.

[49] Debaisieux P, Gastaldi L. Le microsporidies parasites des larves de Simulium. Cellule 1919 ; 30: 185-213.

[50] Debaisieux P. Etudes cytologiques sur quelques microsporidies. Cellule 1928; 38: 389-450.

[51] Mercier L. Sur le dévelopment et la structure des spores de Thelohania giardi Henneguy. C R Acad Sci Paris 1908; 146: 34-8.

[52] Mercier L. Contribution à l'étude de la sexulité chez les Myxosporidies et chez les Microsporidies. Mem Class Sci Acad Royal Belg 1909; 2: 50.

[53] Thélohan P. Observations sur les Myxosporidies et essai de classification de ce organismes. Bull Soc Philom 1892; 4: 165-78.

[54] Thélohan P. Sur la présence d'une capsule à filament dans les spores microsporidies. C R Acad Sc Paris 1894; 118: 1425-7.

[55] Thélohan P. Recherches sur les Myxosporidies. Bulletin scientifique de la France et de la Belgique 1895; 26: 100-394.

[56] Pérez C. Microsporidies parasites des crabes d'Arcachon. Note préliminaire. Soc sci Arcachon 1905; 8.

[57] Henneguy F, Thélohan P. Myxosporidies parasites des muscles chez quelques crustacés décapodes. Ann Microgr 1892; 4: 617-41.

[58] Stempell W. Ueber Thélohania mülleri (L. Pfr.). Zool Jahrb Anat 1902; 16: 235-72.

[59] Stempell W. Über Nosema anomalum Moniez. Arch Protistenkd 1904; 4: 1-42.

[60] Léger L, Hesse E. Cnidosporidies des larves d'éphémères. C R Acad Sci Paris 1910; 150: 411-4.

[61] Weissenberg R. Mikrosporidien, Myxosporidien und Chlamydozoen als Zellparasiten von Fischen. Verh Deutsch Zool Ges 1922; 27: 41-3.

[62] Chatton E. Un complexe xéno-parasitaire morphologique et physiologique Neresheimeria paradoxa chez Fritillaria pellucida. C R Acad Sci Paris 1920; 171: 55-7.

[63] Weissenberg R. Über einige Mikrosporidien aus Fischen (Nosema lophii Doflein, Glugea anomala Moniez, Glugea hertwigi nov. spec). Sitzungsberichte der Gesellschaft der Naturfreunde, Berlin 1911; 8: 344-51.

[64] Weissenberg R. Beiträge zur Kenntins des Zeugungskreises der Mikrosporidien Glugea anomala Moniez und hertwigi Weissenberg. Arch Mikr Anat 1913; 82 Abt 2: 81-163.

[65] Weissenberg R. Intracellular development of the microsporidien Glugea anomala Moniez in hypertrophying migratory cells of the fish Gasterosteus aculeatus L., an example of the formation of "xenoma tumors". J Protozool 1968; 15: 44-57.

[66] Doflein F. Studien zur Naturgeschichte der Protozoen. III. Über Myxosporidien. Zool Jahrb Abt Anat 1898; 11: 281-350.

[67] Doflein F. Fortschritte auf dem Gebiete der Myxosporidienkunde. Zusammenfassende Übersicht. Zool Zentralbl 1899; 6: 361-79.

[68] Doflein F. Die Protozoen als Parasiten und Krankheitserreger nach biologischen Gesichtspunkten dargestellt. Jena, Germany: Gustav Fischer Verlag 1901.

[69] Doflein F. Das System der Protozoen. Arch Protistenkunde 1902; 1: 169-92.

[70] Auerbach M. Die Cnidosporidien (Myxosporidien Actinomyxidien Microsporidien). Leipzig, Germany: Verlag von Dr. Werner Klinkhardt 1910.

[71] Nöller W. Kleine Beobachtung an parasitischen Protozoen (Zugleich vorläufige Mitteilung über die Befruchtung und Sporogonie von Lankesterella minima Chaussat). Arch Protist 1920; 41: 169-89.

[72] Zwölfer W. Die Prébine des Schwammspinners (Porthetria dispar L.) und Goldafters (Nygmia phaerrhoea) eine neue wirtschaftlich bedeutungsvolle Infektionskrankheit. Verh d Ges angew Entom Berlin 1927.

[73] Kudo R. A biologic and taxonomic study of the Microsporidia. Ill Biol Monogr 1924; 9: 1-268 (reprinted in 1970 by Johnson Reprint Corporation, New York, USA).

[74] Kramer JP. Observations on the emergence of the microsporidian sporoplasm. J Insect Pathol 1960; 2: 433-9. 
[75] Kramer JP. Nosema kingi sp. n., a microsporidian from Drosophila willistoni Sturtevant, and its infectivity for other muscoids. J Invertebr Pathol 1964; 6: 491-99.

[76] Kramer JP. Nosema necatrix sp. $\mathrm{n}$. and Thelohania diazoma sp. n., microsporidians from the armyworm Pseudaletia unipuncta (Haworth). J Invertebr Pathol 1965; 7: 117-21.

[77] Alger NE, Undeen AH. The control of a microsporidian, Nosema $\mathrm{Sp}$., in an anopheline colony by an egg-rinsing technique. J Invertebr Pathol 1970; 15: 321-7.

[78] Vávra J, Undeen AH. Nosema algerae n. sp. (Cnidospora, Microsporida) a pathogen in a laboratory colony of Anopheles stephensi Liston (Diptera, Culicidae). J Protozool 1970; 17: 240-9.

[79] Maddox JV. Studies on a microsporidiosis of the armyworm Pseudaletia unipunctata (Haworth). Ph.D. thesis, University of Illinois, Urbana, Ill. 1966.

[80] Undeen AH. A proposed mechanism for the germination of microsporidian (Protozoa: Microspora) spores. J Theor Biol 1990; 142: 223-5.

[81] Undeen AH, Avery SW. Effects of anions on the germination of Nosema algerae (Microspora: Nosematidae) spores. J Invertebr Pathol 1988; 52: 84-9.

[82] Undeen AH, Frixone E. The role of osmotic pressure in the germination of Nosema algerae spores. J Protozool 1991; 37: 561-7.

[83] Undeen AH, Frixone E. Structural alterations of the plasma membrane in spores of the microsporidium Nosema algerae on germination. J Protozool 1991; 38: 511-8.

[84] Undeen AH. Microsporidia (Protozoa): A handbook of biology and research techniques. Gainesville, Florida:Southern Cooperative Series Bulletin 1997.

[85] Kudo R. Handbook of Protozoology. Springfield, Illinois: Charles C. Thomas 1931.

[86] Kudo R Protozoology. Springfield, Illinois: Charles C. Thomas 1939, 1946, 1954, 1966.

[87] Kudo R. Protozoology (fifth edition, third printing). Springfield, Illinois: Charles C. Thomas, 1977.

[88] Sprague V. Founders Lecture. Richard Roksabro Kudo, the man and his hobby. J Invertebr Pathol 1990; 55: 297-305.

[89] Kudo R. Eine neue Methode die Sporen von Nosema bombycis Nägeli mit ihren ausgeschnellten Polfäden dauerhaft zu präparieren und deren Länge genauer zu bestimmen. Zool Anz 1913; 48: 36871.

[90] Kudo R. On the structure of some microsporidian spores. J Parasitol 1920; 6: 178-82.

[91] Kudo R, Daniels EW. An electron microscope study of the spore of a microsporidian, Thelohania californica. J Protozool 1963; 10: 112-20.

[92] Daniels EW. Richard Roksabro Kudo 1886-1967. J Protozool 1967; 14: 790-1.

[93] Fischer HI. Richard Roksabro Kudo. Ill State Acad Sci 1967; 60: 329-36.

[94] Jírovec O. Studien über Mikrosporidien. Vestn Cesk Spol Zool 1936; 4: 1-75.

[95] Weiser J. Contribution to the classification of microsporidia. Vestn Cesk Spol Zool 1977; 41: 308-20.

[96] Larsson JIR. Insect pathological investigations on Swedish Thysanura. II. A new microsporidian parasite of Petrobius brevistylis (Microcoryphia, Machilidae): description of the species and creation of two new genera and a new family. Protistologica 1980; 16: 85-101.

[97] Jírovec O, Bouček B, Fiala J. Life under the microscope: a fascinating excursion into a strange lilliputian world. London, UK: Spring Books 1962

[98] Weiser J. Klíč kurčování Mikrosporidií. Práce Morav prir spol 1947; 18: 1-64.

[99] Weiser J. Nemoci hmyzu. Academia, Prague, Czech Republic 1966.

[100] Weiser J. Mikrobiologicheskie metody borby s vrednymi nasekomymi, Kolos, Moscow, Russia, 1972.

[101] Weiser J. An atlas of insect diseases. Academia, Prague, Czech Republic, 1969, 1977.

[102] Weiser J. Mikrosporidie: Monograficka Studie. (Dissertation) Akad Sci Prague, Czech Republic 1959a

[103] Weiser J. Nosema laphygmae $\mathrm{n}$. sp. and the internal structure of the microsporidian spore. J Insect Pathol 1959b; 1: 52-9.

[104] Davidson EW, Denis Burges H. History of the Society for Invertebrate Pathology. J Invertebr Pathol 2005; 89: 2-11.
[105] Brooks WM. Host-parasitoid-pathogen interactions. In: Beckage NE, Thompson SN, Federici BA, Eds. Parasites and pathogens of insects, San Diego, USA: Academic Press 1993; pp. 231-72.

[106] Doby JM, Saguez F. Weiseria, genre nouveau de microsporidies et Weiseria laurenti n. sp., parasite de larves de Prosimulium inflatum Davies, 1957 (Dipteres: Paranematoceres) C R Acad Sci Paris 1964; 259: 3614-7.

[107] Weiser J, Žižka Z. Brachiola gambiae sp.n., the microsporidian parasite of Anopheles gambiae and A. melas in Liberia. Acta Protozool 2004; 43: 73-80.

[108] Weiser J. Die Mikrosporidien als Parasiten der Insekten. Monogr Angew Entomol 1961; 17: 1-149.

[109] Sprague V, Ormières RR, Manier JF. Creation of a new genus and a new family in the microsporidia. J Invertebr Pathol 1972; 20: 228-31.

[110] Kellen WR, Lipa JJ. Thelohania californica n. sp., a microsporidian parasite of Culex tarsalis Coquillet. J Invertebr Pathol 1960; 2: $1-2$.

[111] Kellen WR, Clark RB, Lindegren JE. Two previously undescribed Nosemas from mosquitoes of Californica (Nosematidae: Microsporidia): J Invertebr Pathol 1967; 9: 19-25.

[112] Lipa JJ. Observations on development and pathogenicity of the parasite of Aporia crataegi L. (Lepidoptera) - Nosema aporiae n.sp. Acta Parasitol 1957; 5: 559-84.

[113] Lipa JJ. Miscellaneous observations on protozoan infections of Nepa cinerea Linneaus including description of previously unknown species of microsporidia, Nosema bialoviesianar $\mathrm{sp}$. n. and Thelohania nepae sp. n. J Invertebr Pathol 1966; 8: 158-66.

[114] Lipa JJ. Nosema leptinotarsae sp. n. a microsporidia parasite of Colorado potato beetle, Leptinotarsa decemlineate (Say). J Invertebr Pathol 1968; 10: 111-5.

[115] Lipa JJ, Hokkanen HMT. Nosema meligethi I. \& R.(Microsporidia) in populations of Meligethes spp. in Europe. Biocontrol Science Techn 1992; 2: 119-25.

[116] Sprague V. Annotated list of species of microsporidia. In: Bulla LE, Cheng TC, Eds. Comparative Pathobiology. Vol. 2. New York, USA: Plenum Press 1977; pp. 31-334.

[117] Issi IV. Microsporidia as a phylum of parasitic protozoa. Protozoology 1986; 10: 6-136.

[118] Canning EU, Lom J. The Microsporidia of Vertebrates. Academic Press, London, United Kingdom(1986)

[119] Canning EU, Vávra J. Phylum Microsporidia Balbiani 1882. In: Lee JJ, Leedale GF, Bradbury P, Eds. An illustrated guide to the protozoa. Second Edition. Lawrence, Kansas: Society of Protozoologists 2000; pp. 39-126.

[120] Canning EU. A new microsporidian, Nosema locustae, n. sp. from the fat body of the african migratory locust Locusta migratoria migratorioides. Parasitology 1953; 43: 287-90.

[121] Sokolova YY, Dolgikh VV, Morzhina EV, Nassonova ES, Issi IV, Terry RS, Ironside JE, Smith JE, Vossbrinck CR. Establishment of the new genus Paranosema based on the ultrastructure and molecular phylogeny of the type species Paranosema grylli Gen. Nov., Comb. Nov. (Sokolova, Selezniov, Dolgikh, Issi 1994), from the cricket Gryllus bimaculatus Deg. J Invertebr Patho 2003; 84: 15972.

[122] Henry JE. Experimental application of Nosema locustae for control of grasshoppers. J Invertebr Pathol 1971; 18: 389-94.

[123] Henry JE, Oma EA. Pest control by Nosema locustae, a pathogen of grasshoppers and crickets. In: Burges HD, Ed. Microbial Control of Pests and Plant Deseases 1970-1980, New York, USA: Academic Press 1981; pp. 573-586.

[124] Weiser J, Wegensteiner R, Žižka Z. Canningia spinidentis gen. et sp. n. (Protista: Microspora), a new pathogen of the fir bark beetle Pityokteines spinidens. Folia Parasitol 1995; 42: 1-10.

[125] Canning EU, Refardt D, Vossbrinck CR, Okamura B, Curry A. New diplokaryotic microsporidia (Phylum Microsporidia) from freshwater bryozoans (Bryozoa, Phylactolaemata). Europ J Protistol 2002; 38: 247-6.5

[126] Canning E, Feist SW, Longshaw M, Okamura B, Anderson CL, Tse MT, Curry A. Microgemma vivaresi n. sp. (Microsporidia, Tetramicridae), infecting liver and skeletal muscle of sea scorpions, Taurulus bubalis (Euphrasen 1786) (Osteichthyes, Cottidae), an inshore, littoral fish. J Eukaryot Microbiol 2005; 52: 1-9.

[127] Sprague V, Becnel JJ. Appendix: checklist of available generic names for microsporidia with type species and type host. In: 
Wittner M, Weiss LM, Eds. The Microsporidia and Microsporidiosis, Washington, USA: ASM Press 1999; pp. 517-530.

[128] Weissenberg R. Microsporidian interactions with host cells. In: Bulla A, Cheng TC, Eds. Comparative Pathobiology, Vol. 1., New York, USA: Plenum Press 1976; pp. 203-237.

[129] Canning EU. The medical importance of Microsporidia. Fol Parasitol 1975; $22: 10$

[130] Franzen C. Microsporidia: how can they invade other cells. Trends Parasitol 2004; 20: 275-9.

[131] Müller A, Trammer T, Chioralia G, Seitz HM, Diehl V, Franzen C. Ribosomal RNA of Nosema algerae and phylogenetic relationship to other microsporidia. Parasitol Res 2000; 86: 18-23.

[132] Krieg A. Über Infektionskrankheiten bei Engerlingen von Melolotha spec. Unter besondererer Berücksichtigung einer Microsporidien-Erkrankung. Zentralbl Bakt Abt II 1955; 108: 535-8.

[133] Huger A. Electron microscope study on the cytology of a microsporidian spore by means of ultrathin sectioning. J Insect Pathol 1960; 2: 84-105.

[134] Steinhaus EA. Report in diagnoses of diseased insects 1944-1950. Hilgardia 1951; 20: 629-78.

[134a] Vávra J. Ètude àu microscope èlectronique de la morphologie et du dévelopment de quelques Microsporidies. C R Acad Sc Paris 1965; 261: 3467-70.

[135] Vávra J, Yachnis AT, Shadduck JA, Orenstein JM. Microsporidia of the genus Trachipleistophora-causative agents of human microsporidiosis: description of Trachipleistophora anthropophthera n. sp. (Protozoa: Microsporidia). J Eukaryot Microbiol 1998; 45: 273-83.

[136] Vávra J. Structure of the microsporidia. In: Bulla A, Cheng TC, Eds. Comparative Pathobiology, Vol. 1. New York, USA: Plenum Press 1976a; pp. 1-85

[137] Vávra J. The development of microsporidia. In: Bulla A, Cheng TC, Eds. Comparative Pathobiology, Vol. 1. New York, USA: Plenum Press 1976a; pp. 87-110.

[138] Vávra J, Maddox JV. Methods in microsporidiology. In: Bulla A, Cheng TC, Eds. Comparative Pathobiology, Vol. 1. New York, USA: Plenum Press 1976a; pp. 281-320.

[139] Vávra J, Sprague V. Glossary for the microsporidia. In: Bulla A, Cheng TC, Eds. Comparative Pathobiology, Vol. 1. New York, USA: Plenum Press 1976a; pp. 341-364.

[140] Vávra J, Larsson JIR. Structure of the microsporidia. In: Wittner M, Weiss LM, Eds. The Microsporidia and Microsporidiosis, Washington, USA: ASM Press 1999; pp. 7-84.

[141] Vávra J. "Polar vesicles" of microsporidia are mitochondrial remnants ("mitosomes"). Fol Parasitol 2005; 52: 193-5.

[142] Dissanaike AS, Canning EU. The mode of emergence of the sporoplasm in microsporidia and its relation to the structure of the spore. Parasitology 1957; 47:92-9.

[142a] Hyliš M, Weiser J, Oborník M, Vávra J. DNA isolation from museum and type collection slides of microsporidia. J Invertebr Pathol 2005; 88: 257-60.

[143] Morgenthaler O. Der Polfaden von Nosema apis Zander. Arch Bienenkunde 1922; 4: 53-60.

[144] Ohshima K. On the function of the polar filament of Nosema bombycis. Parasitology 1937; 29: 220-4.

[145] Lom J, Vávra J. The mode of sporoplsmextrusion in microsporidian spores. Acta Protozool 1963; 1: 81-9.

[146] West AF. The biology of a species of Nosema (Sporozoa, Microsporidia) in the flour beetle Tribolium confusum. J Parasitol 1960; 46: 747-53

[147] Weidner E. The microsporidian spore invasion tube. The ultrastructure, isolation, and characterization of the protein comprising the tube. J Cell Biol 1976; 71: 23-34.

[148] Weidner E, Byrd W. The microsporidian spore invasion tube. II. Role of calcium in the activation of invasion tube discharge. J Cell Biol 1982; 93: 970-5.

[149] Weidner E. The microsporidian spore invasion tube. III. Tube extrusion and assembly. J Cell Biol 1982; 93: 976-9.

[150] Pleshinger J, Weidner E. The microsporidian spore invasion tube. IV. Discharge activation begins with $\mathrm{pH}$-triggered $\mathrm{Ca} 2+$ influx. J Cell Biol 1985; 100: 1834-8.

[151] Weidner E. Ultrastructural study of microsporidian invasion into cells. Z Parasitenkd 1972; 40: 227-42.

[152] Weidner E. Interactions between Encephalitozoon cuniculi and macrophages. Parasitophorous vacuole growth and the absence of lysosomal fusion. Z Parasitenkd 1975; 47: 1-9.
[153] Weidner E, Sibley LD. Phagocytized intracellular microsporidian blocks phagosome acidification and phagosome-lysosome fusion. J Protozool 1985; 32: 311-7.

[154] Keohane EM, Weiss LM. The structure, function, and composition of the microsporidian polar tube. In: Wittner M, Weiss LM, Eds. The Microsporidia and Microsporidiosis, Washington, USA: ASM Press 1999; pp. 196-224.

[155] $\mathrm{Xu} \mathrm{Y,} \mathrm{Weiss} \mathrm{LM.} \mathrm{The} \mathrm{microsporidian} \mathrm{polar} \mathrm{tube:} \mathrm{a} \mathrm{highly} \mathrm{special-}$ ised invasion organelle. Int J Parasitol 2005; 35: 941-53.

[156] Franzen C, Fischer S, Schroeder J, Bleiss W, Schneuwly S, Schölmerich J, Salzberger B. In vitro cultivation of an insect microsporidian Tubulinosema ratisbonensis in mammalian cells. J Eukaryot Microbiol 2005; 52: 349-55.

[157] Schottelius J, Schmetz C, Kock NP, Schuler T, Sobottka I, Fleischer B. Presentation by scanning electron microscopy of the life cycle of microsporidia of the genus Encephalitozoon. Microbes Infect 2000; 2: 1401-6.

[158] Bigliardi E, Sacchi L. Cell biology and invasion of the microsporidia. Microbes Infect 2001; 3: 373-9.

[159] Magaud A, Achbarou A, Desportes-Livage I. Cell invasion by the microsporidium Encephalitozoon intestinalis. J Eukaryot Microbiol 1997; 44: 81S

[160] Foucault C, Drancourt M. Actin mediates Encephalitozoon intestinalis entry into the human enterocyte-like cell line, Caco-2. Microb Pathog 2000; 28: 51-8.

[161] Vivarès CP, Méténier G. The microsporidian Encephalitozoon. Bioessays 2001; 23: 194-202.

[162] Franzen C. How do microsporidia invade cells? Folia Parasitol 2005; 52: 36-40.

[163] Couzinet S, Cejas E, Schittny J, Deplazes P, Weber R, Zimmerli S. Phagocytic uptake of Encephalitozoon cuniculi by nonprofessional phagocytes. Infect Immun 2000; 68:6939-45.

[164] Franzen C, Müller A, Hartmann P, Salzberger B. Cell invasion and intracellular fate of Encephalitozoon cuniculi (Microsporidia). Parasitology 2005; 130: 285-92.

[165] David L, Weiser J. Role of hemocytes in the propagation of a microsporidian infection in Larvae of Galleria mellonella. J Invertebr Pathol 1993; 63: 212-3.

[166] Cali A. Morphogenesis in the genus Nosema. Proc. IV Int. Colloq. Insect Pathol., College Park, MD, USA. 1971; pp. 431-8.

[167] Franzen C, Futerman PH, Schroeder J, Salzberger B, Kraaijeveld AR. An ultrastructural and molecular study of Tubulinosema kingi Kramer (Microsporidia: Tubulinosematidae) from Drosophila melanogaster (Diptera: Drosophilidae) and its parasitoid Asobara tabida (Hymenoptera: Braconidae). J Invertebr Pathol 2006; 91 158-67.

[168] Franzen C, Fischer S, Schroeder J, Schölmerich J, Schneuwly S: Morphological and molecular investigations of Tubulinosema ratisbonensis gen. nov, sp., nov. (Microsporidia: Tubulinosematidae fam. nov.), a parasite infecting a laboratory colony of Drosophila melanogaster (Diptera: Drosophilidae). J Eukaryot Microbiol 2005; 52: 141-52.

[169] Cali A, Takvorian PM. Developmental morphology and life cycles of the microsporidia. In: Wittner M, Weiss LM, Eds. The Microsporidia and Microsporidiosis, Washington, USA: ASM Press 1999; pp. 85-128.

[170] Fowler JL, Reeves EL. Spore dimorphism in a microsporidian isolate. J Protozool 1974a; 21: 538-42.

[171] Fowler JL, Reeves EL. Detection of relationships among microsporidan isolates by electrophoretic analysis: Hydrophobic extracts. J Invertebr Pathol 1974b; 23: 3-12.

[172] Pilley BM. A new genus, Vairimorpha (Protozoa: Microsporidia), for Nosema necatrix Kramer 1965: pathogenicity and life cycle in Spodoptera exempta (Lepidoptera: Noctuidae). J Invertebr Pathol 1976; $28:$ 177-83.

[173] Hazard EI, Weiser J. Spores of Thelohania in adult female Anopheles: development and transovarial transmission, and redescription of T. legeri Hesse and T. obesa Kudo. J Protozool 1968; 15: 81723.

[174] Hazard EI, Oldacre SW. Revision of Microsporidia (Protozoa) close to Thelohania, with descriptions of one new family, eight new genera and thirteen new species. U S Dept Agric Tech Bull 1975; 1530: 1-104

[175] Jouvenaz DP, Hazard EI. New family, genus and species of microsporidia (Protozoa, Microsporidia) from the tropical fire ant So- 
lenopsis gemminata (Fabricius) (Insecta. Formicidae). J Protozool 1978; 25: 24-9.

[176] Sweeney AW, Hazard EI, Graham MF. Intermediate host for an Amblyospora sp. (Microspora) infecting the mosquito Culex annulirostris. J Invertebr Pathol 1985; 46: 98-102.

[177] Andreadis TG. Experimental transmission of a microsporidian pathogen from mosquitoes to an alternate copepod host. Proc Natl Acad Sci USA 1985; 82: 5574-7.

[178] Weiser J, Hostounskey Z. Production of spores of Nosema plodiae Kellen et Lindegren in Mamestra brassicae L. after different infective dosage, I. Vestn Cesk Spol Zool 1972; 3: 234-7.

[179] Anthony DE, Savage KE, Hazard EI, Avery SW, Boston MD, Oldacre SW. Field tests with Nosema algerae Vávra and Undeen (Microsporidia, Nosematidae) against Anopheles albimanus Weidmann in Panama. Misc Publ Entomol Soc Am 1978; 11: 17-28.

[180] Hazard EI, Anthony DW. A redescription of the genus Parathelohania Codreanu 1966 (Microsporidia: Protozoa) with a reexamination of previously described species of Thelohania Henneguy 1892 and descriptions of two new species of Parathelohania from anopheline mosquitos. U S Dept Agric Tech Bull 1974; 1505: 1-26.

[181] Brooks WM. In Memoriam Edwin I. Hazard (1935-1985). J Invertebr Pathol 1985; 46: 217-8.

[182] Becnel JJ, Sprague V, Fukuda T, Hazard EI. Development of Edhazardia aedis (Kudo, 1930) n. g., n. comb. (Microsporida: Amblyosporidae) in the mosquito Aedes aegypti (L.) (Diptera: Culicidae). J Protozool 1989; 36: 119-30.

[183] Iwano H, Ishihara R. Dimorphic development of Nosema bombycis spores in gut epithelium of larvae of the silkworm, Bombyx mori. J Seric Sci Jpn 1991a; 60: 249-56.

[184] Iwano H, Ishihara R. Dimorphism of spores of Nosema spp. in cultured cell. J Invertebr Pathol 1991b; 57: 211-9.

[185] De Graaf D, Raes DC, Jacobs FJ. Spore dimorphism in Nosema apis (Microsporidia: Nosematidae) development cycle. J Invertebr Pathol 1994; 63: 92-4.

[186] Johnson MA, Becnel JJ, Undeen AH. A new sporulation sequence in Edhazardia aedis (Microsporidia: Culicosporidae), a parasite of the mosquito Aedes aegypti (Diptera: Culicidae). J Invertebr Pathol 1997; 70: 69-75.

[187] Solter LF, Maddox JV. Timing of an early sporulation sequence of microsporidia in the genus Vairimorpha (Microsporidia: Burenellidae). J Invertebr Pathol 1998; 72: 323-9.

[188] Keeling PJ, Fast NM. Microsporidia: biology and evolution of highly reduced intracellular parasites. Annu Rev Microbiol 2002; 56: 93-116.

[189] Ishihara R, Hayashi Y. Some properties of ribosomes from the sporoplasm of Nosema bombycis. J Invertebr Pathol 1968; 11: 37785 .

[190] Curgy JJ, Vávra J, Vivarès C. Presence of ribosomal RNAs with prokaryotic properties in Microsporidia, eukaryotic organisms. Biol Cell 1980; 38: 49-51.

[191] Vossbrinck CR, Woese CR. Eukaryotic ribosomes that lack a 5.8S RNA. Nature 1986; 320: 287-8.

[192] Vossbrinck CR, Maddox JV, Friedman S, Debrunner-Vossbrinck BA, Woese CR. Ribosomal RNA sequences suggests microsporidia are extremely ancient eukaryotes. Nature 1987; 326: 411-4.

[193] Kamaishi T, Hashimoto T, Nakamura Y, Masuda Y, Nakamura F, Okamoto K, Shimizu M, Hasegawa M. Complete nucleotide sequences of the genes encoding translation elongation factors $1 \alpha$ and 2 from a microsporidian parasite, Glugea plecoglossi: implications for the deepest branching of eukaryotes. J Biochem 1996; 120: 1095-103.

[194] Cavalier-Smith T. Eukaryotes with no mitochondria. Nature 1987 ; 326: 332-3.

[195] Germot A, Philippe H, Le Guyader H. Evidence for loss of mitochondria in microsporidia from a mitochondrial-type HSP70 in Nosema locustae. Mol Biochem Parasitol 1997; 87: 159-68.

[196] Hirt RP, Healy B, Vossbrinck CR, Canning EU, Embley TM. A mitochondrial Hsp70 orthologue in Vairimorpha necatrix: molecular evidence that microsporidia one contained mitochondria. Curr Biol 19971; 7: 995-8.

[197] Peyretaillade E, Biderre C, Peyret P, Méténier G, Gouy M, Vivarès. Microsporidia, amitochondrial protists, posses a 70-kDa heat shock protein gene of mitochondrial evolutionary origin. Mol Biol Evol 1998; 15: 683-9.

[198] Katinka MD, Duprat S, Cornillot E, Metenier G, Thomarat F, Prensier G, Barbe V, Peyretaillade E, Brottier P, Wincker P, Delbac F,
El Alaoui H, Peyret P, Saurin W, Gouy M, Weissenbach J, Vivarès $\mathrm{CP}$. Genome sequence and gene compaction of the eukaryote parasite Encephalitozoon cuniculi. Nature 2001; 414: 450-3.

[199] Williams BAP, Hirt RP, Lucocq JM, Embley TM. A mitochondrial remnant in the microsporidian Trachipleistophora hominis. Nature 2002; 418: 865-9.

[200] Edlind TD, Li J, Visvesvara GS, Vodkin MH, McLaughlin GL, Katiyar SK. Phylogenetic analysis of $\beta$-tubulin sequences from amitochondrial protozoa. Mol Phyl Evol 1996; 5: 359-67.

[201] Fast NM, Logsdon Jr JM, Doolittle WF. Phylogenetic analysis of the TATA box binding protein (TBP) gene from Nosema locustae: evidence for a microsporidia-fungi relationship and sliceosomal intron loss. Mol Biol Evol 1999; 16: 1415-9.

[202] Forterre P, Philippe H. Where is the root or the universal tree of life? Bioessays 1999; 21: 871-9.

[203] Weiss LM. The First United Workshop on Microsporidia from Invertebrate and Vertebrate Hosts. Fol Parasitol 2005; 52 : 1-7.

[204] Tuzet O, Maurand J, Fize A, Michel R, Fenwich B. Proposition d'un nouveau cadre systematique por les genres Microsporidies. C R Acad Sci Paris 1971; 272: 1268-71.

[205] Larsson JIR. Ultrastructure, function, and classification of microsporidia. Prog Protistol 1986; 1: 325-90.

[206] Larsson JIR. Identification of microsporidian genera (Protozoa, Microspora): aguide with comments on taxonomy. Arch Protistenkd 1988; 136: 1-37.

[207] Baker MD, Vossbrinck CR, Maddox JV, Undeen AH. Phylogenetic relationships among Vairimorpha and Nosema species (Microspora) based on ribosomal RNA sequence data. J Invertebr Pathol 1994; 64: 100-6.

[208] Franzen C, Nassonova ES, Schölmerich J, Issi IV. Transfer of the members of the genus Brachiola (Microsporidia) to the genus Anncaliia based on ultrastructural and molecular data. J Euk Microbiol 2006; 53: 26-35.

[209] Sokolova YY, Issi IV, Morzhina EV, Tokarev YS, Vossbrinck CR Ultrastructural analysis supports transferring Nosema whitei Weiser 1953 to the genus Paranosema and creation a new combination, Paranosema whitei. J Invertebr Pathol 2005; 90: 122-6.

[210] Issi IV, Lipa JJ. Report on identification of Protozoa pathogenic for insects in the Soviet Union (1961-1966), with descriptions of some new species. Acta Protozool 1968; 6: 281-90.

[211] Vidtmann SS, Sokolova YV. The description of the new genus Larssonia gen. n. based on the ultrastructure analysis of microsporidium (Pleistophora) obtrusa from Daphnia pulex (Cladocera). Parazitologiya 1994; 28: 202-13.

[212] Weiser J, David L. A light and electron microscopic study of Larssoniella resinellae $\mathrm{n}$. gen., n. sp. (Microspora, Unikaryonidae), a parasite of Petrova resinella (Lepidoptera, Tortricidae) in Central Europe. Arch Protistenkd 1980; 147: 405-10.

[213] Slamovits CS, Williams BAP, Keeling PJ. Transfer of Nosema locustae (Microsporidia) to Antonospora locustae n. com. based on molecular and ultrastructural data. J Eukaryot Microbiol 2004; 51: 207-13.

[214] Keeling PJ, Fast NM, Law JS, Williams BA, Slamovits CH. Comparative genomics of microsporidia. Folia Parasitol 2005; 52: 8-14.

[215] Williams BAP, Slamovits CH, Patron NJ, Fast NM, Keeling PJ. A high frequency of overlapping gene expression in compacted eukaryotic genomes. Proc Natl Acad Sci USA 2005; 102: 10936-41.

[216] Hinkle G, Morrison HG, Sogin ML. Genes coding for reverse transcriptase, DNA-directed RNA polymerase, and chitin synthase from the microsporidian Spraguea lophii. Biol Bull 1997; 193: 250-1;

[216a] Vossbrinck CR, Baker MD, Didier ES, Debrunner-Vossbrinck BA, Shadduck JA. Ribosomal DNA sequences of Encephalitozoon hellem and Encephalitozoon cuniculi: species identification and phylogenetic construction. J Eukaryot Microbiol 1993; 40: 354-62.

[217] Mittleider D, Green LC, Mann VH, Michael SF, Didier ES, Brindley PJ. Sequence survey of the genome of the opportunistic microsporidian pathogen, Vittaforma corneae. J Eukaryot Microbiol 2002; 49: 393-401.

[217a] Silveira H, Canning EU. Vittaforma corneae n. comb. for the human microsporidium Nosema corneum Shadduck, Meccoli, Davis $\&$ Font, 1990, based on its ultrastructure in the liver of experimentally infected athymic mice. J Eukaryot Microbiol 1995; 42: 15865

[218] Slothouber Galbreath JGM, Smith JE, Terry RS, Becnel JJ, Dunn AM. Invasion success of Fibrillanosema crangonycis, n.sp., n.g.: a 
novel vertically transmitted microsporidian parasite from the invasive amphipod host Crangonyx pseudogracilis. Int J Parasitol 2004; 34: 235-44.

[219] Vossbrinck CR, Debrunner-Vossbrinck BA. Molecular phylogeny of the microsporidia: ecological, ultrastructural and taxonomic considerations. Fol Parasitol 2005; 52: 131-42.

[220] Larsson JIR. Molecular versus morphological approach to microsporidian classification. Fol Parasitol 2005; 52: 143-44.

[221] Canning EU. The microsporidian parasites of Platyhelminthes: their morphology, development, transmission and pathogenicity. Commonwealth Institute of Helminthology miscellaneous publications No. 2. Bucks, UK: Commonwealth Agricultural Bureaux 1975 .

[222] Wright JH, Craighead EM. Infectious motor paralysis in young rabbits. J Exp Med 1922; 36: 135-40.

[223] Levaditi C, Nicolau S, Schoen R. L'étiologie de l'encéphalite. C R Acad Sci Paris 1923a; 177: 985-8.

[224] Levaditi C, Nicolau S, Schoen R. L'agent étiologique de l'encéphalite épizootique du lapin (Encepahlitozoon cuniculi). C R Soc Biol Paris 1923b; 89: 984-6.

[225] Levaditi C, Nicolau S, Schoen R. Novelles données sur l'Encephalitozoon cuniculi. C R Soc Biol Paris 1923c; 89: 115762.

[226] Wenyon CM. Protozoology. Vol 1. London, UK: Baillière, Tindall and Cox 1926.

[227] Nelson JB. An intracellular parasite resembling a microsporidian, associated with ascites in Swiss mice. Proc Soc Exp Biol Med 1962; 109: 714-7.

[228] Lainson R, Garnham PCC, Killick-Kendrick R, Bird RG. Nosematosis, a microsporidial infection of rodents and other animals, including man. Br Med J 1964; 2: 470-2.

[229] Weiser J. On the taxonomic position of the genus Encephalitozoon Levaditi, Nicolau \& Schoen, 1923 (Protozoa: Microsporidia). Parasitology 1964; 54: 749-51

[230] Issi IV, Krylova SV, Nicolaeva VM. The ultrastructure of the microsporidium Nosema meligethi and establishment of the new genus Anncaliia. Parazitologiya 1993; 27: 127-33.

[231] Doby JM, Jeannes A, Rault B. Thelohania apodemi n.sp., première microsporidie du genre Thelohania obersvée chez un Mammifère. C R Acad Sci Paris 1963; 257: 248-51.

[232] Matsubayashi H, Koike T, Mikata T, Hagiwara S. A case of Encephalitozoon-like-body infection in man. Arch Pathol 1959; 67: 181-7.

[233] Weiser J. Early experiences with microsporidia of man and mammals. Folia Parasitol 1993; 40: 257-60.

[234] Bergquist NR, Stintzing G, Smedman L, Waller T, Andersson T. Diagnosis of encephalitozoonosis in man by serological tests. $\mathrm{Br}$ Med J 1984; 288: 902

[234a] Margileth AM, Strano AJ, Chandra R, Neafie R, Blum M, McCully RM. Dissiminated nosematosis in an immunologically compromised infant. Arch Pathol 1973; 95:145-50.

[235] Ashton N, Wirasinha PA Encephalitozoonosis (nosematosis) of the cornea. Br J Ophthalmol 1973; 57: 669-74.

[236] Pinnolis M, Egbert PR, Font RL, Winter FC. Nosematosis of the cornea. Case report, including electron microscopic studies. Arch Ophthalmol 1981; 99: 1044-7.

[237] Modigliani R, Bories C, Le Charpentier Y, Salmeron M, Messing B, Galian A, Rambaud JC, Lavergne A, Cochand Priollet B, Desportes I. Diarrhoea and malabsorption in acquired immune deficiency syndrome: a study of four cases with special emphasis on opportunistic protozoan infestations. Gut 1985; 26: 179-87.

[238] Desportes I, Le Charpentier Y, Galian A, Bernard F, Cochand Priollet B, Lavergne A, Ravisse P, Modigliani R. Occurrence of a new microsporidan: Enterocytozoon bieneusi n.g., n. sp., in the enterocytes of a human patient with AIDS. J Protozool 1985; 32: 2504.

[239] Orenstein JM. Microsporidiosis in the acquired immunodeficiency syndrome. J Parasitol 1991; 77: 843-64

[240] Dobbins WO, Weinstein WM. Electron microscopy of the intestine and rectum in acquired immunodeficiency syndrome. Gastroenterology 1984; 86: 1063

[241] Cali A, Owen RL. Intracellular development of Enterocytozoon, a unique microsporidian found in the intestine of AIDS patients. J. Protozool. 1990: 37: 145-55.
[242] Dobbins WO, Weinstein WM. Electron microscopy of the intestine and rectum in acquired immunodeficiency syndrome. Gastroenterology $1985 ; 88: 738-49$

[243] Canning EU, Hollister WS. Enterocytozoon bieneusi (Microspora): prevalence and pathogenicity in AIDS patients. Trans R Soc Trop Med Hyg 1990; 84: 181-6.

[244] Sandfort J, Hannemann A, Gelderblom H, Stark K, Owen RL, Ruf B. Enterocytozoon bieneusi infection in an immunocompetent patient who had acute diarrhea and who was not in fected with the human immunodeficiency virus. Clin Infect Dis 1994; 19: 514-6.

[245] Bryan RT, Schwartz DA. Epidemiology of Microsporidiosis. In: Wittner M, Weiss LM, Eds. The Microsporidia and Microsporidiosis, Washington, USA: ASM Press 1999; pp. 502-516.

[246] Terada S, Reddy KR, Jeffers LJ, Cali A, Schiff ER. Microsporidan hepatitis in the acquired immunodeficiency syndrome. Ann Intern Med 1987; 107: 61-2.

[247] Zender HO, Arrigoni E, Eckert J, Kapanci Y. A case of Encephalitozoon cuniculi peritonitis in a patient with AIDS. Am J Clin Pathol 1989; 92: 352-6.

[248] Didier ES, Didier PJ, Friedberg DN, Stenson SM, Orenstein JM, Yee RW, Tio FO, Davis RM, Vossbrinck C, Millichamp N, Shadduck JA. Isolation and characterization of a new human microsporidian, Encephalitozoon hellem (n. sp.), from three AIDS patients with keratoconjunctivitis. J Infect Dis 1991; 163: 617-21.

[249] Schwartz DA, Visvesvara GS, Diesenhouse MC, Weber R, Font RL, Wilson LA, Corrent G, Serdarevic ON, Rosberger DF, Keenen PC,Grossniklaus H, Hewan-Lowe K, Bryan R. Pathologic features and immunofluorescent antibody demonstration of ocular microsporidiosis (Encephalitozoon hellem) in seven patients with acquired immunodeficiency syndrome. Am J Ophthalmol 1993; 115: 285-92.

[250] De Groote MA, Visvesvara G, Wilson ML, Pieniazek NJ, Slemenda SB, daSilva AJ, Leitch GJ, Bryan RT, Reves R. Polymerase chain reaction and culture confirmation of disseminated Encephalitozoon cuniculi in a patient with AIDS: successful therapy with albendazole. J Infect Dis 1995; 171: 1375-8.

[251] Franzen C, Schwartz DA, Visvesvara GS, Müller A, Schwenk A, Salzberger B, Fätkenheuer G, Hartmann P, Mahrle G, Diehl V, Schrappe M. Immunologically confirmed disseminated, asymptomatic Encephalitozoon cuniculi infection of the gastrointestinal tract in a patient with AIDS. Clin Infect Dis 1995; 21: 1480-4.

[252] Mathis A, Weber R, Deplazes P. Zoonotic potential of the microsporidia. Clin Microbiol Rev 2005; 18: 423-45.

[253] Orenstein JM, Dieterich DT, Kotler DP. Systemic dissemination by a newly recognized intestinal microsporidia species in AIDS. AIDS 1992; 6: 1143-50.

[254] Cali A, Kotler DP, Orenstein JM. Septata intestinalis n. g., n. sp., an intestinal microsporidian associated with chronic diarrhea and dissemination in AIDS patients. J Eukaryot Microbiol 1993; 40: 101-12.

[255] Hartskeerl RA, Van Gool T, Schuitema AR, Didier ES, Terpstra WJ. Genetic and immunological characterization of the microsporidian Septata intestinalis Cali, Kotler and Orenstein, 1993: reclassification to Encephalitozoon intestinalis. Parasitology 1995 110: 277-85

[256] Hollister WS, Canning EU, Weidner E, Field AS, Kench J, Marriott DJ. Development and ultrastructure of Trachipleistophora hominis n.g., n.sp. after in vitro isolation from an AIDS patient and inoculation into athymic mice. Parasitology 1996; 112: 143-54.

[257] Cali A, Meisler DM, Lowder CY, Lembach R, Ayers L, Takvorian PM, Rutherford I, Longworth DL, McMahon J, Bryan RT. Corneal microsporidioses: characterization and identification. J Protozool 1991; 38: 215S-7S.

[258] Cali A, Takvorian PM. Ultrastructure and development of Pleistophora ronneafiei $\mathrm{n}$. sp., a microsporidium (Protista) in the skeletal muscle of an immune-compromised individual. J Eukaryot Microbiol 2003; 50: 77-85.

[259] Shadduck JA, Meccoli RA, Davis R, Font RL. Isolation of a microsporidian from a human patient. J Infect Dis 1990; 162: 773-6.

[260] Cali A, Takvorian PM, Lewin S, Rendel M, Sian CS, Wittner M Tanowitz HB, Keohane E, Weiss LM. Brachiola vesicularum, N.G., N. Sp., a new microsporidium associated with AIDS and Myositis. J Eukaryot Microbiol 1998; 45: 240-51.

[261] Sprague V. Nosema connori n. sp., a microsporidian parasite of man. Trans Am Microsc Soc 1974; 93: 400-3. 
[262] Coyle CM, Weiss LM, Rhodes LV, Cali A, Takvorian PM, Brown DF, Visvesvara GS, Xiao L, Naktin J, Young E, Gareca M, Colasante G, Wittner M. Fatal myositis due to the microsporidian Brachiola algerae, a mosquito pathogen. N Engl J Med 2004; 351: 42-7.

[263] Visvesvara GS, Belloso M, Moura H, da Silva AJ, Moura INS, Leitch GJ, Schwartz DA, Chevez-Barrios P, Wallace S, Pieniazek $\mathrm{NJ}$, Goosey JD. Isolation of Nosema algerae from the cornea of an immunocompetent patient. J Eukaryot Microbiol 1999; 46: 10S.

[264] Becnel JJ, Andreadis G. Microsporidia in insects. In: Wittner M, Weiss LM, Eds. The Microsporidia and Microsporidiosis, Washington, USA: ASM Press, 1999; pp. 447-501.

[265] Dunn AM, Terry RS, Smith JE. Transovarial transmission in the microsporidia. Adv Parasitol 2001; 48: 57-100.

[266] Didier ES, Stovall ME, Green LC, Brindley PJ, Sestak K, Didier PJ. Epidemiology of microsporidiosis: sources and modes of transmission. Vet Parasitol 2004; 126: 145-66.

[267] Snowden KF, Shadduck JA. Microsporidia in higher vertebrates. In: Wittner M, Weiss LM, Eds. The Microsporidia and Microsporidiosis, Washington, USA: ASM Press 1999; pp. 393-417.

[268] Wasson K, Peper RL. Mammalian microsporidiosis. Vet Pathol 2000; 37: 113-28.

[269] Snowden K, Phalen DN. Encephalitozoon infection in birds. Seminars in Avian and Exotic Pet Medicine 2004; 13: 94-9.

[270] Enriques FJ, Taren D, Cruz-Lopez A, Muramoto M, Palting JD, Cruz P. 1998. Prevalence of intestinal encephalitozoonosis in Mexico. Clin Infect Dis 1998; 26:1227-9.

[271] Bornay-Llinares FJ, da Silva AJ, Moura H, Schwartz DA, Visvesvara GS, Pieniazek NJ, Cruz-Lopez A, Hernandez-Jauregui P, Guerrero J, Enriquez FJ. Immunologic, microscopic, and molecular evidence of Encephalitozoon intestinalis (Septata intestinalis) infection in mammals other than humans. J Infect Dis 1998; 178: 820-6.

[272] Deplazes P, Mathis A, Müller C, Weber R. Molecular epidemiology of Encephalitozoon cuniculi and first detection of Enterocytozoon bieneusi in faecal samples of pigs. J Eukaryot Microbiol 1996; 43: 93S

[273] Breitenmoser AC, Mathis A, Burgi E, Weber R, Deplazes P. High prevalence of Enterocytozoon bieneusi in swine with four genotypes that differ from those identified in humans. Parasitology 1999; 118: 447-53.

[274] Lom J. Introductory remarks on microsporidia in the AIDS era. Fol Parasitol 1993; 40: 225-6.

[275] Didier ES Vossbrinck CR, Baker MD, Rogers LB, Bertucci DC, Shadduck JA. Identification and charcterization of three Encephalitozoon cuniculi strains. Parasitology 1995; 111: 411-21.

[276] Didier ES. Microsporidiosis: an emerging and opportunistic infection in humans and animals. Acta Trop 2005; 94: 61-76.

[277] McInnes EF, Stewart CG. The pathology of subclinical infection of Encephalitozoon cuniculi in canine dams producing pups with overt encephalitozoonosis. J S Afr Vet Assoc 1991; 62: 51-4.

[278] Trammer T, Dombrowski F, Doehring M, Maier W, Seitz HM. Opportunistic properties of Nosema algerae (Microspora), a mosquito parasite, in immunocompromised mice. J Eukaryot Microbiol 1997; 44: 258-62

[279] Koudela B, Visvesvara GS, Vávra J. The human isolate of Brachiola algerae (Phylum Microspora): development in SCID mice and description of its fine structure features. Parasitology 2001; 123: $153-62$

[280] Avery SW, Undeen AH. The isolation of microsporidia and other pathogens from concentrated ditch water. J Am Mosq Control Assoc 1987; 3: 54-8

[281] Dowd SE, Gerba CP, Pepper IL. Confirmation of the humanpathogenic microsporidia Enterocytozoon bieneusi, Encephalitozoon intestinalis, and Vittaforma corneae in water. Appl Environ Microbiol 1998; 64: 3332-5.

[282] Sparfel JM, Sarfati C, Liguory O, Caroff B, Dumoutier N, Gueglio B, Billaud E, Raffi F, Molina JM, Miegeville M, Derouin F. Detection of microsporidia and identification of Enterocytozoon bieneusi in surface water by filtration followed by specific PCR. J Eukaryot Microbiol 1997; 44: 78S.

[283] Cotte L, Rabodonirina M, Chapuis F, Bailly F, Bissuel F, Raynal C, Gelas P, Persat F, Piens MA, Trepo C. Waterborne outbreak of intestinal microsporidiosis in persons with and without human immunodeficiency virus infection. J Infect Dis 1999; 180: 2003-8.
[284] Hutin YJF, Sombardier MN, Liguory O, Sarfati C, Derouin F, Modai J, Molina JM. Risk factors for intestinal microsporidiosis in patients infected with human immunodeficiency virus infection: a case-control study. J Infect Dis 1998; 178: 904-7.

[285] Franzen C, Müller A. Cryptosporidia and microsporidia - waterborne diseases in the immunocompromised host. Diag Microbiol Infect Dis 1999; 34: 245-62.

[286] Hollister WS, Canning EU, Willcox A. Evidence for widespread occurrence of antibodies to Encephalitozoon cuniculi (Microspora) in man provided by ELISA and other serological tests. Parasitology 1991; 102: 33-43.

[287] Singh M, Kane GJ, Mackinlay L, Quaki I, Yap EH, Ho BC, Ho LC, Lim KC. Detection of antibodies to Nosema cuniculi (Protozoa : Microscoporidia) in human and animal sera by the indirect fluorescent antibody technique. Southeast Asian J Trop Med Public Health 1982; 13: 110-3.

[288] van Gool T, Vetter JC, Weinmayr B, Van Dam A, Derouin F, Dankert J. High seroprevalence of Encephalitozoon species in immunocompetent subjects. J Infect Dis 1997; 175: 1020-4.

[289] van Gool T, Biderre C, Delbac F, Wentink-Bonnema E, Peek R, Vivares CP. Serodiagnostic studies in an immunocompetent individual infected with Encephalitozoon cuniculi. J Infect Dis 2004; 189: 2243-9.

[290] Franzen C, Müller A. Molecular techniques for detection, species differentiation, and phylogenetic analysis of microsporidia. Clin Microbiol Rev 1999; 12: 243-85.

[291] Franzen C, Müller A. Microsporidiosis: human diseases and diagnosis. Microbes Infect 2001; 3: 389-400

[292] Weber R, Schwartz DA, Deplazes P. Laboratory diagnosis of microsporidiosis. In: Wittner M, Weiss LM, Eds. The Microsporidia and Microsporidiosis, Washington, USA: ASM Press 1999; pp. 315-362.

[293] Weber R, Bryan RT, Owen RL, Wilcox CM, Gorelkin L, Visvesvara GS. Improved light-microscopical detection of microsporidia spores in stool and duodenal aspirates. N Engl J Med 1992; 326: 161-6.

[294] van Gool T, Snijders F, Reiss P, Eeftinck Schattenkerk JK, van den Bergh Weerman MA, Bartelsman JF, Bruins JJ, Canning EU, Dankert J. Diagnosis of intestinal and disseminated microsporidial infections in patients with HIV by a new rapid fluorescence technique. J Clin Pathol 1993; 46: 694-9.

[295] Vávra J, Dahbiova R, Hollister WS, Canning EU. Staining of microsporidian spores by optical brighteners with remarks on the use of brighteners for the diagnosis of AIDS associated human microsporidioses. Folia Parasitol 1993; 40: 267-72.

[296] Franzen C, Müller A, Salzberger B, Fätkenheuer G, Eidt S, Mahrle G, Diehl V, Schrappe M. Tissue diagnosis of intestinal microsporidiosis using a fluorescent stain with Uvitex 2B. J Clin Pathol 1995; 48: 1009-10.

[297] Giang TT, Kotler DP, Garro ML, Orenstein JM. Tissue diagnosis of intestinal microsporidiosis using the chromotrope-2R modified trichrome stain. Arch Pathol Lab Med 1993; 117: 1249-51.

[298] Weiss LM, Vossbrinck CR. Microsporidiosis: molecular and diagnostic aspects. Adv Parasitol 1998; 40: 351-95.

[299] Weiss LM, Vossbrinck CR. Molecular biology, molecular phylogeny, and molecular diagnostic approaches to the microsporidia. In: Wittner M, Weiss LM, Eds. The Microsporidia and Microsporidiosis, Washington, USA: ASM Press 1999; pp. 129171.

[300] Visvesvara GS. In vitro cultivation of microsporidia of clinical importance. Clin Microbiol Rev 2002; 15: 401-13.

[301] Trager W. The hatching of spores of Nosema bombycis Nägeli and the partial development of the organism in tissue cultures. J Parasitol 1937; 23: 226-7.

[302] Ishihara R, Sohi SS. Infection of ovarian tissue culture of Bombyx mori by Nosema bombycis spores. J Invertebr Pathol 1966; 8: 53840.

[302a] Undeen AH. The growth of Nosema algerae in pig kidney cell cultures. J Protozool 1975; 22: 107-10.

[303] Kurrti TJ, Brooks MA. Growth of microsporidian parasite in cultured cells of tent caterpillars (Malacostoma). Curr Topics Microbiol Immunol 1971; 55: 204-8.

[304] Kurrti TJ, Brooks MA. The rate of development of a microsporidian in moth cell cultures. J invertebr Pathol 1977; 29: 126-32.

[305] Trammer T, Chioralia G, Maier W, Seitz HM. In vitro replication of Nosema algerae (Microsporidia), a parasite of anopheline 
mosquitoes, in human cells above $36^{\circ} \mathrm{C}$. J Eukaryot Microbiol 1999; 46:464-8

[306] Moura H, da Silva AJ, Moura INS, Schwartz DA, Leitch GJ, Wallace S, Pieniazek NJ, Wirtz RA, Visvesvara GS. Characterization of Nosema algerae isolates after continuous cultivation in mammalian cells at $37^{\circ} \mathrm{C}$. J Eukaryot Microbiol 1999; 46: 14-6S

[307] Shadduck JA. Nosema cuniculi: in vitro isolation. Science 1969; 166: 516-7.

[308] Vávra J, Bedrnik P, Cinatl J. Isolation and in vitro cultivation of the mammalian microsporidian Encephalitozoon cuniculi. Folia Parasitol 1972; 19: 349-54.

[309] Visvesvara GS, Leitch GJ, Moura H, Wallace S, Weber R, Bryan RT. Culture, electron microscopy, and immunoblot studies on a microsporidian parasite isolated from the urine of a patient with AIDS. J Protozool 1991; 38: 105S-11S.

[310] Visvesvara G, Leitch GJ, Pieniazek NJ, Da Silva AJ, Wallace S, Slemenda SB, Weber R, Schwartz DA, Gorelkin L, Wilcox CM. Short-term in vitro culture and molecular analysis of the microsporidian, Enterocytozoon bieneusi. J Eukaryot Microbiol 1995; 42: 506-10.

[311] Weiser J. Microsporidia in invertebrates. In: Bulla A, Cheng TC, Eds. Comparative Pathobiology, Vol. 1., New York, USA: Plenum Press 1965; pp. 163-202.

[312] Lom J. A catalogue of described genera and species of microsporidians parasitic in fish. Syst Parasitol 2002; 53: 81-99.

[313] Shaw RW, Kent ML. Fish microsporidia. In: Wittner M, Weiss LM, Ed. The Microsporidia and Microsporidiosis, Washington, USA: ASM Press 1990; pp. 418-446.

[314] Sandholzer LA, Nostrand T, Young L. Studies on an ichthyosporidian-like parasite of ocean pout (Zoareces anguillaris). US Fish Wild Serv Spec Sci Rep 1945; 31: 1-12

[315] Haley AJ. Microsporidian parasite, Glugea hertwigi, in American smelt from the Grat Bay region, New Hampshire. Trans Am Microsc Soc 1954; 83: 84-90.

[316] Kotler DP, Orenstein JM. Clinical syndromes associated with microsporidiosis. In: Wittner M, Weiss LM, Eds. The Microsporidia and Microsporidiosis, Washington, USA: ASM Press 1999; pp. 258-292

[317] Weber R, Bryan RT, Schwartz DA, Owen RL. Human microsporidial infections. Clin Microbiol Rev 1994; 7: 426-61.

[318] Lopez-Velez R, Turrientes MC, Garron C, Montilla P, Navajas R, Fenoy S, del Aguila C. Microsporidiosis in travelers with diarrhea from the tropics. J Travel Med 1999; 6: 223-7.

[319] Müller A, Bialek R, Kämper A, Fätkenheuer G, Salzberger B, Franzen C. Detection of microsporidia in travelers with diarrhea. J Clin Microbiol 2001; 39: 1630-2.

[320] Raynaud L, Delbac F, Broussolle V, Rabodonirina M, Girault V, Wallon M, Cozon G, Vivarès CP, Peyron F. Identification of Encephalitozoon intestinalis in travelers with chronic diarrhea by specific PCR amplification. J Clin Microbiol 1998; 36: 37-40.

[321] Davis RM, Font RL, Keisler MS, Shadduck JA. Corneal microsporidiosis. A case report including ultrastructural observations. Ophthalmology 1990; 97: 953-7.

[322] Rauz S, Tuft S, Dart JK, Bonshek R, Luthert P, Curry A. Ultrastructural examination of two cases of stromal microsporidial keratitis. J Med Microbiol 2004; 53: 775-81.

[323] Deplazes P, Mathis A, van Saanen M, Iten A, Keller R, Tanner I, Glauser MP, Weber R, Canning EU. Dual microsporidial infection due to Vittaforma corneae and Encephalitozoon hellem in a patient with AIDS. Clin Infect Dis 1998; 27: 1521-4.

[324] Ledford DK, Overman MD, Gonzalvo A, Cali A, Mester SW, Lockey RF. Microsporidiosis myositis in a patient with the acquired immunodeficiency syndrome. Ann Intern Med 1985; 102: 628-30.

[325] Field AS, Marriott DJ, Milliken ST, Brew BJ, Canning EU, Kench JG, Darveniza P, Harkness JL. Myositis associated with a newly described microsporidian, Trachipleistophora hominis, in a patient with AIDS. J Clin Microbiol 1996; 34: 2803-11.

[326] Curry A, Beeching NJ, Gilbert JD, Scott G, Rowland PL, Currie BJ. Trachipleistophora hominis infection in the myocardium and skeletal muscle of a patient with AIDS. J Infect 2005; 51: 139-44.

[327] Yachnis AT, Berg J, Martinez-Salazar A, Bender BS, Diaz L, Rojiani AM, Eskin TA, Orenstein JM. Disseminated microsporidiosis especially infecting the brain, heart, and kidneys. Report of a newly recognized pansporoblastic species in two symptomatic AIDS patients. Am J Clin Pathol 1996; 106: 535-43.
[328] Juarez SI, Putaporntip C, Jongwutiwes S, Ichinose A, Yanagi T, Kanbara H. In vitro cultivation and electron microscopy characterization of Trachipleistophora anthropophthera isolated from the cornea of an AIDS patient. J Eukaryot Microbiol 2005; 52: 179-90.

[329] Pariyakanok L, Jongwutiwes S. Keratitis caused by Trachipleistophora anthropophthera. J Infect 2005; 51 : 325-8.

[330] Chupp GL, Alroy J, Adelman LS, Breen JC, Skolnik PR. Myositis due to Pleistophora (Microsporidia) in a patient with AIDS. Clin Infect Dis 1993; 16: 15-21.

[331] Grau A, Valls ME, Williams JE, Ellis DS, Muntane MJ, Nadal C. Miositis por Pleistophora en un paciente con SIDA. Med Clin 1996; 107: 779-81.

[332] Goetz M, Eichenlaub S, Pape GR, Hoffmann RM. Chronic diarrhea as a result of intestinal microsposidiosis in a liver transplant recipient. Transplantation 2001; 71: 334-7.

[333] Guerard A, Rabodonirina M, Cotte L, Liguory O, Piens MA Daoud S, Picot S, Touraine JL. Intestinal microsporidiosis occurring in two renal transplant recipients treated with mycophenolate mofetil. Transplantation 1999; 68: 699-707.

[334] Gumbo T, Hobbs RE, Carlyn C, Hall G, Isada CM. Microsporidia infection in transplant patients. Transplantation 1999; 67: 482-4.

[335] Katznelson H, Jamiesin CA. Control of nosema disease of honeybees with fumagillin. Science 1952; 115: 70-1.

[336] Shadduck JA. Effect of fumagillin on in vitro multiplication of Encephalitozoon cuniculi. J Protozool 1980; 27: 202-8.

[337] Diesenhouse MC, Wilson LA, Corrent GF, Visvesvara GS, Grossniklaus HE, Bryan RT. Treatment of microsporidial keratoconjunctivitis with topical fumagillin. Am J Ophthalmol 1993; 115: 293-8.

[338] Rosberger DF, Serdarevic ON, Erlandson RA, Bryan RT, Schwartz DA, Visvesvara GS, Keenan PC. Successful treatment of microsporidial keratoconjunctivitis with topical fumagillin in a patient with AIDS. Cornea 1993; 12: 261-5.

[339] Friedberg DN, Ritterband DC. Ocular microsporidiosis. In: Wittner M, Weiss LM, Eds. The Microsporidia and Microsporidiosis, Washington, USA: ASM Press 1999; pp. 292-314.

[340] Molina JM, Tourneur M, Sarfati C, Chevret S, de Gouvello A, Gobert JG, Balkan S, Derouin F. Fumagillin treatment of intestinal microsporidiosis. N Engl J Med 2002; 346: 1963-9.

[341] Didier ES. Effects of albendazole, fumagillin, and TNP-470 on microsporidial replication in vitro. Antimicrob Agents Chemother 1997; 41: 1541-6.

[342] Didier ES, Maddry JA, Brindley PJ, Stovall ME, Didier PJ. Therapeutic strategies for human microsporidia infections. Expert Rey Anti Infect Ther 2005; 3: 419-34.

[343] Beauvais B, Sarfati C, Challier S, Derouin F. In vitro model to assess effect of antimicrobial agents on Encephalitozoon cuniculi. Antimicrob Agents Chemother 1994; 10: 2440-8.

[344] Haque A, Hollister WS, Willcox A, Canning EU. The antimicrosporidial activity of albendazole. J Invertebr Pathol 1993; 62: 171-77.

[345] Molina JM, Oksenhendler E, Beauvais B, Sarfati C, Jaccard A, Derouin F, Modai J. Disseminated microsporidiosis due to Septata intestinalis in patients with AIDS: clinical features and response to albendazole therapy. J Infect Dis 1995; 171: 245-9.

[346] Blanshard C, Ellis DS, Tovey DG, Dowell S, Gazzard BG. Treatment of intestinal microsporidiosis with albendazole in patients with AIDS. AIDS 1992; 6: 311-3.

[347] Dieterich DT, Lew EA, Kotler DP, Poles MA, Orenstein JM. Treatment with albendazole for intestinal disease due to Enterocytozoon bieneusi in patients with AIDS. J Infect Dis 1994; 169: 17883.

[348] Molina JM, Goguel J, Sarfati C, Chastang C, Desportes-Livage I, Michiels JF, Maslo C, Katlama C, Cotte L, Leport C, Raffi F, Derouin F, Modai J. Potential efficacy of fumagillin in intestinal microsporidiosis due to Enterocytozoon bieneusi in patients with HIV infection: results of a drug screening study. AIDS 1997; 11 1603-10.

[349] Carr A, Marriott D, Field A, Vasak E, Cooper DA. Treatment of HIV-1-associated microsporidiosis and cryptosporidiosis with combination antiretroviral therapy. Lancet 1998; 351: 256-61.

[350] Conteas CN, Berlin OG, Speck CE, Pandhumas SS, Lariviere MJ, $\mathrm{Fu} \mathrm{C}$. Modification of the clinical course of intestinal microsporidiosis in acquired immunodeficiency syndrome patients by immune status and anti-human immunodeficiency virus therapy. Am J Trop Med Hyg 1998; 58: 555-8 
[351] Foudraine NA, Weverling GJ, van Gool T, Roos MT, de Wolf F, Koopmans PP, van den Broek PJ, Meenhorst PL, van Leeuwen R, Lange JM, Reiss P .Improvement of chronic diarrhoea in patients with advanced HIV-1 infection during potent antiretroviral therapy. AIDS 1998; 12: 35-41.
[352] Goguel J, Katlama C, Sarfati C, Maslo C, Leport C, Molina JM. Remission of AIDS-associated intestinal microsporidiosis with highly active antiretroviral therapy. AIDS 1997; 11: 1658-9.

[353] Miao YM, Awad-El-Kariem FM, Franzen C, Ellis DS, Müller A, Counihan HM, Hayes PJ, Gazzard BG. Eradication of cryptosporidia and microsporidia following successful antiretroviral therapy. J Acquir Immune Defic Syndr 2000; 25: 124-9. 